\title{
A taxonomical study of Rhoicosphenia Grunow (Bacillariophyceae) with a key for identification of selected taxa
}

\author{
Zlatko Levkov ${ }^{1}$, Katarina CAPut Minalić ${ }^{2} \&$ Luc ECTOR $^{3}$ \\ ${ }^{1}$ Institute of Biology, Faculty of Natural Sciences, Skopje, R. Macedonia; \\ e-mail: zlevkov@iunona.pmf.ukim.edu.mk \\ ${ }^{2}$ Department of Molecular Biology, Faculty of Sciences, University of Zagreb, Croatia; \\ e-mail: kcaput@biol.pmf.hr \\ ${ }^{3}$ Department of Environment and Agro-Biotechnologies (EVA), Public Research Centre - Gabriel Lippmann, Rue \\ du Brill 41, L-4422 Belvaux, Luxembourg; e-mail: ector@lippmann.lu
}

\begin{abstract}
A taxonomical study of 15 Rhoicosphenia species based on light and scanning electron microscope was performed. The genus Rhoicosphenia is characterized by frustule heterovalvy, with a fully developed raphe on the concave valve (referred also as $\mathrm{R}$ valve) and reduced raphe on the convex valve (referred as $\mathrm{D}-\mathrm{valve}$ ). One of the most frequently reported species, $R$. abbreviata, is characterized by narrow, linear valves with low stria density. In contrast, Rhoicosphenia macedonica has broadly clavate valves with a high stria density. According to valve shape $R$. macedonica is similar to the widely distributed marine species $R$. marina, but the latter has broader valves $(8.5-11 \mu \mathrm{m}$ wide) and a lower stria density. Both, $R$. tenuis and $R$. baicalensis have similar valve sizes and shapes, but the latter is characterized by a lower stria density on the D-valve. Rhoicosphenia baltica is a brackish water species with protracted and subcapitate base poles, narrower valves and lower stria density compared with $R$. marina. The main distinctive features of $R$. flexa are the absence of a raphe branch on the head pole of the convex D-valve, and coarsely punctate striae. $R$. genuflexa has isopolar, linear valves. Four other species have different combinations of characters (valve size, shape and stria density) compared to above mentioned species, and their formal descriptions are provided. Rhoicosphenia lacustris sp. nov. is characterized by larger and broadly clavate valves, densely spaced striae and elongated areolae. Rhoicosphenia affinis sp. nov. has broadly lanceolate valves with attenuated and slightly protracted head pole with a higher stria density compared to $R$. abbreviata. Rhoicosphenia adriatica sp. nov. is a brackish water species having narrow, linear valves, with a high stria density. Finally, R. omblaensis sp. nov. has a characteristic central area, which appears as a narrow hyaline area around the central pores.
\end{abstract}

Key words: Rhoicosphenia, morphology, taxonomy, ultrastructure, new species, dichotomous key

\section{Introduction}

The genus Rhoicosphenia GRUNOw is characterized by heterovalvy and a dissimilar raphe system on both valves. It received some more attention in the early 1980's when, in a series of papers, basic information on the ultrastructure of the vegetative cell, auxospore including the perizonium, and initial cell of the freshwater species $R$. curvata (KüTZING) GrunOw were presented (MANn 1982a, b, 1984). Similar investigations were performed on the marine species $R$. genuflexa (KütZING) Medlin (Medlin \& Fryxell 1984a, b). Finally, these studies resulted in the description of a new family: Rhoicospheniaceae (MANN 1984).

The genus comprises species with hetero- polar or isopolar valves which are flexed in the girdle view (Round et al. 1990). Valves are dissimilar in both shape and structure. The concave valve (usually referred to as $\mathrm{R}$-valve) possesses a fully developed raphe system, while the convex (usually referred as the D-valve) possesses reduced raphe branches. The internal proximal raphe fissures on the $\mathrm{R}$-valve are hook-shaped, and curved in the same direction as the external distal raphe fissures. The D-valve is characterized by a strongly reduced raphe system. In one species (R. flexa) the distal raphe branches are absent. Internally, the raphe fissures are dissimilar: the proximal fissures can be crookshaped or hook-shaped, while distal raphe fissure can be crook-shaped or slightly bent to linear 
and not bent. Each stria is composed of a single row of areolae, although occasionally two areolae within a stria can be observed. Biseriate striae are not a consistent character for the genus. Sieve membranes occlude the areolae. The external foramina can be round to a narrow elongated slit. Shape of the foramina is a constant character among different species. Internally the striae are separated by strongly developed interstriae (referred to as transapical costae or verminae). Valve margins are thickened and form pseudosepta at the poles. The valvocopula is modified to fit and interlock with the pseudosepta.

In a study of gomphonemoid diatom taxa, LANGe-BERTALOT (1980) synonymized $R$. curvata (KütZING) GRUNOW with $R$. abbreviata (C. Agardh) LANGE-BertaLot, giving nomenclatural priority to the species described by AGARDH (1831) as Gomphonema abbreviatum C. AGARDH, instead of G. curvatum KÜTZING (KÜTZING 1833). Since then, most studies on Rhoicosphenia were mainly ecological with reference to a potential use as an indicator of eutrophication (e.g. KeLLY \& WhITTON 1995) and pollution (VAN DAm et al. 1994). More recently, in two separate studies of the ancient Lake Ohrid, two new species, $R$. macedonica LeVkov \& Krstic and $R$. tenuis LeVkov \& Nakov were described (Levkov et al. 2007; LevKov \& NAKOV 2008).

Rhoicosphenia is as a relatively small genus. Fourtanier \& KOCIOLEK (2008) list 54 taxa names associated with Rhoicosphenia, most of which, according to VanLandingham (1978), are considered as synonyms of $R$. curvata. However, several infraspecific taxa of $R$. curvata were described from fully marine or brackish water habitats and have different morphometric features (see Table 1), thus their conspecificity with $R$. curvata $(=R$. abbreviata $)$ is questionable.

In this study, light microscope (LM) and scanning electron microscope (SEM) observations were performed on 15 Rhoicosphenia taxa; seven freshwater and eight brackish/marine representatives. The present paper was focused on morphometrical and ultrastructural features of selected Rhoicosphenia taxa using type material and other related samples. The data collected will provide the basis for further taxonomic investigations of additional taxa belonging to this genus.

\section{Material and methods}

Most of the samples and slides used in this study are deposited in the Friedrich Hustedt Centre for Diatom Study, Bremerhaven and in the Macedonian National Diatom Collection (MKDNC). The type slides for $R$. fracta (Schumann) DE Toni and $R$. linearis Østrup were loaned from the Academy of Natural Sciences of Philadelphia (ANSP) and Botanical Garden and Museum in Copenhagen, respectively (Table 2). Diatom slides from Lakes Ohrid and Dojran (Macedonia), and Ombla River (Croatia), were prepared by acid digestion with $\mathrm{HCl}$ followed by $\mathrm{K}_{2} \mathrm{MnO}_{4}$ The residual acids were removed through a series of distilled $\mathrm{H}_{2} \mathrm{O}$ dilutions and the acid-free sample was mounted in Naphrax $^{\circledR}$. Photomicrographs were made on a Zeiss Axioplan microscope with an Axiocam MRc digital camera and a Nikon E-800 microscope equipped with a digital Nikon Coolpix 4500 camera. For SEM, samples of cleaned material were dried onto stubs and coated with gold-palladium. SEM micrographs were made with a Cambridge Instruments S4 Stereoscan and Jeol 6301F Scanning Electron Microscope. Terminology for the valves in Rhoicosphenia follows MANN (1982a): the concave valve with fully developed raphe system is referred to as the $\mathrm{R}$-valve, while the convex with diminutive raphe branches is referred to as the D-valve.

Nutrients and silica $\left(\mathrm{NO}_{3}^{-}, \mathrm{NH}_{4}^{+}, \mathrm{NO}_{2}^{-}, \mathrm{SiO}_{4}{ }^{2-}\right.$, $\mathrm{PO}_{4}{ }^{3-}$ ), and oxygen concentration in Ombla River were determined using methods proposed by STRICKLAND \& PARSONS (1972).

\section{Observations and discussion}

In total, 15 species of Rhoicosphenia have been observed. Their morphometrical and ecological features are given in Table 3. Morphometrical features of other, already described Rhoicosphenia taxa, are also included in Table 1. Data for these described species are taken from their protologue or original illustrations.

Rhoicosphenia abbreviata (C. Agardh) LangeBertalot (Figs 1a-v, 2a-g, 3a-f)

Rhoicosphenia abbreviata (C. AGARDH) LANGEBertalot 1980, p. 586, figs 1A, 3C-D, 5A.

Basionym: Gomphonema abbreviatum C. Agardh 1831, p. 34.

Synonym: Rhoicosphenia curvata (KüTZING) Grunow 1860, p. 511.

Several populations of this species have been observed during this study, but only two populations are depicted here. The majority of the images 
(Figs 1a-p) originate from the slide RAB2/1 labelled as "Rhoicosphenia curvata" prepared from a sample collected by B. Auerswald (Rabenhorst exsiccata - Die Algen Sachsens). The other images (Figs 1q-v) originate from the reference slide (ZU2/38 in BRM) prepared by H. LANGEBERTALOT from the type material of Gomphonema abbreviatum. Most of the specimens present on the reference slides for G. abbreviatum (ZU2/38) are lying in an oblique position or in girdle view, thus limiting image quality (Fig. 1q). However, five valves are depicted here from the BRM slide (Figs 1r-v). Both populations are in accordance with the lectotype chosen by LANGE-BERTALOT (1980, fig. 1A).

LM observations (Figs 1a-v): In girdle view, frustules have a bent wedge shape (Figs 1a, q). Valves are heteropolar, linear to narrowly clavate with a narrowly rounded head pole and attenuated base pole. Valve length varies from 14 to $52 \mu \mathrm{m}$, and the valve width is $5-7 \mu \mathrm{m}$. The concave R-valve has a fully developed raphe with large central pores (Figs $1 \mathrm{~b}-\mathrm{g}$, r), while the convex D-valve has a reduced raphe system with short raphe slits lying close to the poles (Figs $1 \mathrm{~h}-\mathrm{p}, \mathrm{s}-\mathrm{v})$. The axial area on the concave $\mathrm{R}-\mathrm{valve}$ is narrow, tapering towards the valve ends. The central area is weakly expressed or absent. In larger specimens the central area has an elliptical shape, and is slightly wider than the axial area (Figs $1 \mathrm{~b}, \mathrm{c})$, while in smaller specimens it cannot be differentiated from the axial area (Figs 1f, g). The axial area on the convex D-valve is moderately wide; it is occasionally wider in the middle part of the valve. Striae on both valves are parallel to weakly radiate throughout the valve length, and distantly spaced, 9-12 in $10 \mu \mathrm{m}$. Areolae within each stria are not visible with LM. A pore field is present at the base pole of both valves.

SEM observations (Figs 2a-g): In girdle view, frustules have a bent wedge shape (Figs 2a, $2 b)$. The cingulum on both thecae comprises three open bands, each bearing a single row of poroids (Figs 2a, b). The concave $\mathrm{R}$-valve is heteropolar with a rounded head pole, and a narrowly rounded base pole (Figs 2b, c, e). The axial area is lanceolate (Fig. 2c). The raphe system is central. The two raphe slits on the $\mathrm{R}$-valve have different lengths, and the raphe branch at the base pole is slightly longer. Externally, the central raphe fissures are expanded and drop-shaped (Figs 2b, c). Internally, the central raphe fissures are crook towards the same side of the valve (Figs $2 \mathrm{~d}$, g). The terminal raphe fissures are curved and continue onto the valve mantle (Fig. 2f). The fissure at the base pole ends close to the edge of the valve mantle (Fig. 2e). The striae are slightly radiate in the middle, becoming parallel towards the poles (Fig. 2c). Each stria comprises a row of elongated areolae. Occasionally, the striae on the valve mantle have two areolae (Fig. 2b), but this is not a consistent character. The areolae are apically elongated with narrow, slit-like external foramina (Figs 2c, e, f) while internally they have wider oblong openings (Fig. 2g). There is an occluded silica plate-like structure (sieve membrane) within the areolae (Fig. 2f). Internally, the interstriae are strongly developed giving a chambered appearance to the areolae (Figs 2d, g). Close to the base pole, a pore field with densely packed areolae is present (Figs $2 \mathrm{~b}, \mathrm{c}, \mathrm{e})$. A clear distinction between the pore field and transapical striae is noticeable on the valve face (Fig. 2e). The foramina composing the pore fields have an oblique orientation, at least on the valve face.

The raphe system on the convex D-valve (Figs 3a-f) is reduced (Fig. 3a). The axial area is moderately wide and tapering towards the poles. The raphe branch on the head pole is a short slit distally that is slightly bent at the dorsal end (Fig. 3b). The proximal raphe fissure is weakly expanded into a pore (Fig. 3b), while internally it is slightly bent (Fig. 3e). The raphe branch on the base pole has an expanded drop-shaped, proximal fissure (Fig. 3c), while internally the proximal raphe fissures are crook-shaped (Fig. $3 \mathrm{f})$. Distally, the raphe continues onto the valve mantle and divides the apical pore field (Fig. 3c). The striae are uniseriate composed of narrow, elongated areolae (Figs 3a-c). Areolae slit-size increases towards valve mantle (Fig. 3b). Striae in the middle of the valve are more distantly spaced (Fig. 3a). Internally, the interstriae are strongly developed and are wider than the striae (Fig. 3d).

Main differential characters of $R$. abbreviata have a low stria density on the D-valve (9-12 in $10 \mu \mathrm{m})$ with more widely spaced striae in the middle of the valve and elongated areolae.

Taxonomical notes: Different concepts and synonymy of this species can be found in the literature. HUSTEDT (1959, p. 431) recognized the var. sessilis MereschKowsKy (marine taxon) as a separate entity. In the same work HustedT (op. cit. p. 432) synonymized $R$. linearis ØSTRUP (a brackish water taxon) with $R$. curvata. PATRICK \& ReIMER (1966, p. 282), and under synonyms of 
Table 1. Compilation of published numerical and ecological data of different Rhoicosphenia taxa.

\begin{tabular}{|c|c|c|c|c|c|}
\hline Taxon & Ecology & $\begin{array}{l}\text { Length } \\
(\mu \mathrm{m})\end{array}$ & $\begin{array}{l}\text { Width } \\
(\mu \mathrm{m})\end{array}$ & $\begin{array}{c}\text { Striae } \\
\mathrm{R} \text {-valve } \\
\text { (in } 1\end{array}$ & $\begin{array}{l}\text { Striae } \\
\text { D-valve } \\
\mu \mathrm{m})\end{array}$ \\
\hline $\begin{array}{l}\text { R. abbreviata (C. AGARDH) LANGE-BERTALOT } \\
(1980, \text { p. } 586, \text { fig. } 1 \text { A) }\end{array}$ & freshwater & $18-19$ & $5-6$ & 11 & $10-11$ \\
\hline $\begin{array}{l}\text { R. adolfi M. SснміDт in SCHMIDT et al. } \\
\text { (1874-1959, fig. } 213: 20-23)\end{array}$ & marine & $20-41$ & $4-5.5$ & $14-16$ & 16 \\
\hline $\begin{array}{l}\text { R. baicalensis SKABITCHEWSKIJ } \\
(1976, \text { p. } 269 \text {, fig. } 1: 7-10)\end{array}$ & freshwater & $18-30$ & $3-5$ & $7-10$ & $8-13$ \\
\hline $\begin{array}{l}\text { R. curvata f. minor M. ScHMIDT in SCHMIDT et al. } \\
(1874-1959 \text {, fig. } 213: 18)\end{array}$ & $\begin{array}{l}\text { freshwater/ } \\
\text { fossil }\end{array}$ & 35.5 & 4.5 & $10-11$ & - \\
\hline $\begin{array}{l}\text { R. curvata var. baicalensis SKVORTzOW et MEYER } \\
(1928 \text {, p. } 32 \text {, fig. } 3: 150)\end{array}$ & freshwater & 62.9 & 6.8 & - & 14 \\
\hline $\begin{array}{l}\text { R. curvata var. baltica (SCHUMANN) Cleve- } \\
\text { Euler }(1953, \text { p. } 53 \text {, figs } 601 \mathrm{n}-\mathrm{p})\end{array}$ & $\begin{array}{l}\text { brackish/ } \\
\text { fossil }\end{array}$ & $55-65$ & 9 & $17-18$ & $17-18$ \\
\hline $\begin{array}{l}\text { R. curvata var. elongata CLEVE-EULER } \\
(1953, \text { p. } 52 \text {, figs } 601 \mathrm{~d}, \mathrm{e})\end{array}$ & $\begin{array}{l}\text { freshwater/ } \\
\text { fossil }\end{array}$ & $33-53$ & $3-5.2$ & $13-15$ & $13-15$ \\
\hline $\begin{array}{l}\text { R. curvata var. fracta (SCHumANN) Cleve } \\
(1895, \text { p. } 166)\end{array}$ & $\begin{array}{l}\text { brackish/ } \\
\text { marine }\end{array}$ & $34-47$ & $5-7$ & 9 & 9 \\
\hline $\begin{array}{l}\text { R. curvata var. genuina CLEvE-EuleR } \\
(1953 \text {, p. } 52 \text {, figs } 601 \mathrm{a}-\mathrm{c})\end{array}$ & $\begin{array}{l}\text { brackish/ } \\
\text { freshwater }\end{array}$ & $15-25$ & $3-5$ & $15-16$ & $15-16$ \\
\hline $\begin{array}{l}\text { R. curvata var. gracilis M. SCHMIDT in SCHMIDT } \\
\text { et al. }(1874-1959, \text { fig. } 213: 17)\end{array}$ & freshwater & 40 & 4.4 & 17 & - \\
\hline $\begin{array}{l}\text { R. curvata var. linearis CLEVE-EULER } \\
(1915, \text { p. } 38)\end{array}$ & $\begin{array}{l}\text { brackish/ } \\
\text { fossil }\end{array}$ & 30 & $\sim 3$ & - & - \\
\hline $\begin{array}{l}\text { R. curvata var. major CLEVE } \\
(1895, \text { p. } 165)\end{array}$ & freshwater & 70 & 8 & 9 & 9 \\
\hline $\begin{array}{l}\text { R. curvata var. sessilis MERESCHKOWSKY } \\
(1902, \text { p. } 44,65 \text {, fig. } 1)\end{array}$ & marine & $24-44.5$ & 7.2 & - & $11-12$ \\
\hline $\begin{array}{l}\text { R. curvata var. subacuta M. SсHмIDT in SсHмIDT } \\
\text { et al. }(1874-1959 \text {, fig. } 213: 6-14,19)\end{array}$ & $\begin{array}{l}\text { marine/fos. } \\
\text { freshwater }\end{array}$ & $34.4-76$ & $7.2-9.5$ & $11-14$ & $10-16$ \\
\hline $\begin{array}{l}\text { R. flexa GiFFEN } \\
(1970, \text { p. } 96 \text {, fig. } 2: 55-58)\end{array}$ & marine & $20-52$ & $5-6.5$ & $8-12$ & $12-13$ \\
\hline $\begin{array}{l}\text { R. fossilis CLEVE-EULER } \\
(1915 \text {, p. } 38 \text {, fig. } 2: 48)\end{array}$ & $\begin{array}{l}\text { marine/ } \\
\text { fossil }\end{array}$ & 60 & 7 & 10 & - \\
\hline $\begin{array}{l}\text { R. genuflexa (Kützing) MEDLIN in MedLIN et } \\
\text { FryxeLl }(1984 b, \text { p. 104) }\end{array}$ & marine & $6-40$ & $3-5$ & 16 & $10-17$ \\
\hline $\begin{array}{l}\text { R. kolbei Å. BERG } \\
(1952 \text {, p. } 30 \text {, figs } 55 \mathrm{a}-\mathrm{c})\end{array}$ & marine & $46-61$ & $6.5-8$ & - & $12-15$ \\
\hline $\begin{array}{l}\text { R. linearis ØsTRUP } \\
(1910, \text { p. } 120 \text {, fig. } 3: 74)\end{array}$ & $\begin{array}{l}\text { marine/ } \\
\text { brackish }\end{array}$ & $63-66$ & 9 & 10 & 9 \\
\hline $\begin{array}{l}\text { R. macedonica LEVKOV et KRSTIC in LEVKOV et } \\
\text { al. (2007, p. } 117 \text {, fig. } 30: 1-17)\end{array}$ & freshwater & $15-49$ & $5-7.5$ & $18-22$ & $22-24$ \\
\hline $\begin{array}{l}\text { R. marina M. SCHMIDT in SCHMIDT et al. } \\
(1874-1959 \text {, fig. } 213: 28-34)\end{array}$ & marine & $28-65$ & $\begin{array}{l}6.6- \\
10.5\end{array}$ & $13-20$ & $18-24$ \\
\hline
\end{tabular}




\begin{tabular}{|c|c|c|c|c|c|}
\hline $\begin{array}{l}\text { R. marina } \text { var. intermedia } \text { M. SсHмIDT in } \\
\text { ScHмIDT et al. (1874-1959, fig. 213: 36-39) }\end{array}$ & marine & $51-66.5$ & $9-10.5$ & $14-15$ & 14-16 \\
\hline $\begin{array}{l}\text { R. marina var. heterostricta M. SСнміDт in } \\
\text { SCHмIDT et al. (1874-1959, fig. 213: 35) }\end{array}$ & marine & 39 & - & $15-16$ & 25 \\
\hline $\begin{array}{l}\text { R. marina var. ? sensu } \AA \text {. Berg et Hessland } \\
(1949 \text {, p. } 185 \text {, fig. } 2: 26)\end{array}$ & marine & 32 & 12 & $12-13$ & $15-20$ \\
\hline $\begin{array}{l}\text { R. pullus M. SCHмiDT in SCHмiDT et al. } \\
\text { (1874-1959, fig. 213: 24-27) }\end{array}$ & freshwater & $11-30$ & 3.5 & 14 & - \\
\hline $\begin{array}{l}\text { R. stauroneiformis SALAH } \\
(1955, \text { p. 93, fig. 2: 2-3) }\end{array}$ & marine & $10-16$ & $3-4$ & 10 & $12-14$ \\
\hline $\begin{array}{l}\text { R. tenuissima ØSTRUP } \\
\text { (1904, p. 151, fig. 2: 28) }\end{array}$ & marine & $20-30$ & 2 & $\sim 25$ & - \\
\hline $\begin{array}{l}\text { R. vanheurcki GRUNOW in VAN HEURCK } \\
(1880-1885 \text {, fig. } 26: 5-9)\end{array}$ & freshwater & $8-9$ & $3-3.5$ & 14 & 16 \\
\hline
\end{tabular}

R. curvata, listed two varieties, var. major CLEVE (fossil, Pitt River, Oregon) and var. subacuta M. SCHMIDT (a marine form from Insel Hainan).

Probably the most radical taxonomic synonymization proposals can be found in the work of VANLANDINGHAM (1978) which included almost all infraspecific taxa as synonyms of $R$. curvata although the origins of these taxa represent a wide range of environments. Some of them have different morphometrical features and cannot be fitted into R. abbreviata sensu stricto (see below). However, observations of the type materials (if available) are necessary to establish the identity of these potentially associated taxa.

The consequences of such a broad taxonomical concept for $R$. abbreviata can also be noticed in valve size ranges and variability in general morphology. KRAMmer \& LANGEBERTALOT (1986) provided a wide range for the stria density of both valves ( $\mathrm{R}$-valve $15-20$ in 10 $\mu \mathrm{m}$; D-valve $11-24$ in $10 \mu \mathrm{m})$. According to the range given by HuSTEDT (1930) and KRAMMER \& Lange-Bertalot (1986), the valve length of $R$. abbreviata varies from 12 to $75 \mu \mathrm{m}$. However, the maximum valve size observed in this study was $52 \mu \mathrm{m}$, which is close to the maximum valve size given by Geitler $(1932,1952)$ and MANN (1984).

Longer valves (up to $76 \mu \mathrm{m}$ ) are illustrated in SCHмidT et al. (1874-1959, fig. 213: 8, 16) under the varieties major CLEVE and subacuta $\mathrm{M}$. SCHмIDT. The variety subacuta is described from marine samples (SCHMIDT et al. 1874-1959, fig. 213: 6, 7), brackish water (op.cit. fig. 213: 9-14), and freshwater fossil deposits (op.cit. fig. 213: $8,19)$. Besides the differences in their ecology, the illustrated valves show a discrepancy in stria density (compare fig. 213: 7 with fig. 213: 13 in SchmidT et al. 1874-1959).

Observations of the sample from the Pitt River show that there are two different taxa present. The first taxon (Figs 1w, $\mathrm{x}$ ) is larger with lanceolate valves, dense striae and resembles $R$. curvata var. major CLEVE. The second taxon (Fig. $1 \mathrm{y})$ has linear valves with lower stria density and resembles $R$. curvata f. minor M. SCHMidT. However, their identity and conspecificity among each other and with $R$. abbreviata need to be verified through further observations.

The identities of populations illustrated by many authors also need to be verified. OKUNO $(1974$, figs 859,860 ) has presented six TEM images and three LM images of a taxon labelled R. curvata. However, it is dissimilar to $R$. abbreviata in respect to more distantly spaced central striae on the D-valve (loc. cit. fig. 859). Similarly, Round (1996, fig. 22) illustrated a frustule of Rhoicosphenia in girdle view, but with the D-valve more exposed, which is characterized by more distantly spaced central stria on the D-valve. A population that closely resembles $R$. abbreviata sensu stricto is depicted in KaWASHIMA \& KoBAyAsi (1996, figs 11A-K). This population is characterized by narrow valves $(\mathrm{W}=4-5.5 \mu \mathrm{m})$ with distantly spaced striae ( $\mathrm{S}=9-12$ in $10 \mu \mathrm{m}$ ). A second population depicted in KaWASHIMa \& Kobayasi (1996, figs 12A-J) has broader valves (up to $8.5 \mu \mathrm{m}$ ) with a higher stria density ( $\mathrm{S}=12$ 16 in $10 \mu \mathrm{m}$ ). Additionally, differences between these two populations may be observed in the size and shape of the areolae (compare fig. 11K 
Table 2. List of slides/samples of the 15 observed Rhoicosphenia species in this study.

\begin{tabular}{|c|c|c|}
\hline Species & Slide & Locality/Sample \\
\hline R. abbreviata & ZU2/38 in BRM & Würzburg, Deutschland, Coll. Agardh Nr. 4682 \\
\hline R. abbreviata & $\mathrm{RAB} 2 / 01$ in $\mathrm{BRM}$ & $\begin{array}{l}\text { Leipzig Wasserfall in den Promenaden, Acc. No. RBH481 in } \\
\text { BRM }\end{array}$ \\
\hline R. adriatica & $\begin{array}{l}\text { Om14/1 in MKDNC } \\
\text { ZU7/15 in BRM }\end{array}$ & $\begin{array}{l}\text { Ombla River, Croatia, periphyton, } 0.5 \mathrm{~m} \text { depth, Acc. No. OM14 in } \\
\text { MKDNC }\end{array}$ \\
\hline R. affinis & 065/19 in BRM & Hai Nan China, Acc. No. AS15c in BRM \\
\hline R. baicalensis & $167 / 51 \mathrm{a}, \mathrm{b}-53$ & Lake Baikal, Maloe More, sediment, 15-20 m. Acc. No. in AS180 \\
\hline R. baicalensis & $167 / 1 a-10 a$ & Baikalsee Olhon Gate $33 \mathrm{~m}$, Acc. No. AS172-176 in BRM \\
\hline R. baltica & $\mathrm{M} 1 / 01$ in BRM & Schleswig-Holstein, Baltic Sea, macrophytes \\
\hline R. flexa & 245/56-60 in BRM & Capetown, South Africa, Acc. No. A205 in BRM \\
\hline R. fracta & ANSP 11214 & Königsberger Lager, Offene Süsswasser \\
\hline R. genuflexa & 245/56-60 in BRM & Capetown, South Africa, Acc. No. A205 in BRM \\
\hline R. lacustris & ZU7/17 & $\begin{array}{l}\text { Lake Dojran, Nov Dojran, Macedonia, macrophytes, Acc. } 2088 \text { in } \\
\text { MKDNC }\end{array}$ \\
\hline R. lacustris & DRM1/1-3 & Lake Dojran, Macedonia, macrophytes, Acc. 1745 in MKDNC \\
\hline R. linearis & CAT-1833 & Jylland, Denmark, Coll. Østrup in Copenhagen (C) \\
\hline R. macedonica & ZL1/36-39 & $\begin{array}{l}\text { Kaneo, Lake Ohrid, Macedonia, macrophytes, Acc. No. ZL589 in } \\
\text { BRM }\end{array}$ \\
\hline R. marina & T\&P 187 & Le Havre, France \\
\hline R. omblaensis & $\begin{array}{l}\mathrm{Om} 7 / 2 \text { in } \mathrm{MKDNC} \\
\mathrm{ZU} 7 / 16 \text { in } \mathrm{BRM}\end{array}$ & $\begin{array}{l}\text { River Ombla estuary, Croatia, periphyton, Acc. No. OM7 in } \\
\text { MKDNC }\end{array}$ \\
\hline R. tenuis & ZU6/37 in BRM & $\begin{array}{l}\text { St. Naum Springs, Lake Ohrid, Macedonia, above-ground springs, } \\
\text { mosses, Acc. No. ZL353 in BRM }\end{array}$ \\
\hline$R$. spec. 1 & SIM7/21 & Baltic Sea, Simonsen Collection in BRM \\
\hline
\end{tabular}

with fig. 12J in KaWASHima \& Kobayasi 1996). The second population depicted in KaWASHIMA \& KoBAYASI (1996) appears similar to $R$. lacustris (Plates 22-24) and it is likely to be conspecific.

The valves of $R$. abbreviata depicted by RiVERA \& BARRALEs (1989, figs 1-17) have more densely and regularly spaced striae (up to 17 in $10 \mu \mathrm{m})$, which appear in oblique orientation (loc. cit. fig. 14). In addition, the areolae are round to elliptical compared to the elongated, slit-like areolae in $R$. abbreviata (Figs 3a-b). The conspecificity of this population with $R$. abbreviata is questionable; however this Chilean population is similar to $R$. adriatica (see below) or belongs to another (undescribed) taxon.

SEM images of $R$. abbreviata sensu lato are depicted in several publications (e.g. Hoagland et al. 1982, Steinman \& McIntiRe 1987), but their identity cannot be verified since the most important features cannot be observed due to low magnification.

In general, valve length was not the main differential character for separation of the species (Table 1). Almost all freshwater Rhoicosphenia taxa have similar valve lengths $(49-60 \mu \mathrm{m})$. However, species may be separated with LM by valve shape and width, as well as stria density on the D-valve as it happens in the Cocconeis 
Table 3. Compilation of numerical and ecological data for the 15 observed Rhoicosphenia species.

\begin{tabular}{llcccc}
\hline Taxon & Ecology & $\begin{array}{c}\text { Length } \\
(\mu \mathrm{m})\end{array}$ & $\begin{array}{c}\text { Width } \\
(\mu \mathrm{m})\end{array}$ & $\begin{array}{c}\text { Striae R-valve } \\
(\text { in } 10 \mu \mathrm{m})\end{array}$ \\
\hline R. abbreviata & freshwater & $14-52$ & $5.0-7.0$ & $9-12$ & $9-12$ \\
R. adriatica & brackish & $13-45$ & $3.5-6$ & $15-18$ & $15-20$ \\
R. affinis & freshwater & $34-65$ & $6.5-8.5$ & $11-14$ & $11-14$ \\
R. baicalensis & freshwater & $16-49$ & $3.5-5.5$ & $9-12$ & $10-12$ \\
R. baltica & brackish & $21-57$ & $4.5-8$ & $15-18$ & $15-18$ \\
R. flexa & marine & $23-55$ & $4.5-7.5$ & $11-15$ & $11-15$ \\
R. fracta & freshwater & $18.5-48.5$ & $4-5.5$ & $8-15$ & $10-12$ \\
R. genuflexa & marine & $6-40$ & $3.0-5.0$ & $14-17$ & $11-17$ \\
R. lacustris & freshwater/brackish & $25-62$ & $6-9$ & $13-15$ & $12-15$ \\
R. linearis & marine/brackish & $35-66$ & $5.5-7$ & $13-17$ & $15-17$ \\
R. macedonica & freshwater & $15-52$ & $5.5-8.5$ & $18-22$ & $22-24$ \\
R. marina & marine & $29-45$ & $8.5-11.0$ & $13-17$ & $16-20$ \\
R. omblaensis & brackish & $18.5-35.5$ & $4.5-6.0$ & $19-23$ & $20-24$ \\
R. tenuis & freshwater & $15-60$ & $3.0-5.0$ & $12-16$ & $13-17$ \\
R. spec. 1 & brackish/marine & $16-24$ & $6.7-8.0$ & $18-20$ & $18-21$ \\
\hline
\end{tabular}

placentula taxa complex, where differences can only be established by size, striae, and areolae density of the rapheless valve (KRAMMER \& LANGE-Bertalot 1991).

Ecology: Rhoicosphenia abbreviata is a widely distributed species in mesotrophic to slightly eutrophic rivers and lakes. Rhoicosphenia abbreviata was frequently observed attached to macrophytes (Cladophora sp.) in late spring and early summer. This taxon was found in oligotrophic and slightly acidic or humic waters, and generally in low abundance.

Rhoicosphenia abbreviata (or it synonym $R$. curvata) has been widely reported from different environments e.g. from fossil deposits, freshwater sites to truly marine waters (M. SchmidT in SchmidT et al. 1874-1959). Many authors later adopted such distributional and ecological points of view. According to HustedT $(1930,1933,1959)$ R. abbreviata is a freshwater to halophilous brackish water, euryhaline species. Similar ecological preferences were also noted by Krammer \& Lange-Bertalot (1986).

HusTEDT identified R. abbreviata (indicating with a label on the slide "Rhoicosphenia curvata") from the Baltic Sea (slide M1/1 in BRM). Observations of this slide revealed that another species is also present, here identified as $R$. baltica (Schumann) Levkov stat. nov (see below). In contrast, PATRICK \& ReIMER (1966) treated this species as freshwater, oligohalobe, which is in agreement with the observations of this study. Other records of $R$. abbreviata may be found in Morales \& VIs (2007, figs 82-88, 93, 94); Rumrich et al. (2000, fig. 84: 8-10), COCQUYT (1998, fig. 40: 5); Krammer \& Lange-Bertalot [1986, fig. 91: 20-25(26?)]. The valves depicted by CARDINAL et al. (1984, figs 85-91) probably belong to $R$. baltica (see below).

\section{Rhoicosphenia baltica (SchumANn) LevKov stat. nov. (Figs 4a-v, 5a-g, 6a-g) \\ Basionym: Rhoicosphenia fracta var. baltica SchUMANN 1867, Schriften der Königlichen Physikalisch- Ökonomischen Gesellschaft zu Königsberg 8, p. 54, fig. 1: 19. \\ Nomenclatural synonym: Rhoicosphenia curvata var. baltica (Schumann) Cleve-Euler 1953, p. 53, figs 601n-p.}

LM observations (Figs 4a-v): In girdle view, frustules have a strongly bent wedge shape (Figs $4 \mathrm{a}, \mathrm{b})$. Valves are heteropolar, narrowly clavate, with valve margins gradually tapering towards the apices. The head pole is narrowly rounded, 
while the base pole is protracted to subcapitate and broadly rounded. Valves are $21-57 \mu \mathrm{m}$ long and $4.5-8 \mu \mathrm{m}$ wide. The concave $\mathrm{R}$-valve has a well-developed filiform raphe with large central pores (Figs $4 \mathrm{c}-\mathrm{j}$ ), while the convex valve has a reduced raphe system with short raphe slits lying close to the poles (Figs $4 \mathrm{k}-\mathrm{v}$ ). The axial area on the concave $\mathrm{R}$-valve is narrow, and linear. The central area is narrowly elliptical and apically elongated, slightly wider than the axial area. The striae on both valves are slightly radiate throughout, 1518 in $10 \mu \mathrm{m}$. Areolae are not visible under LM. The pore field is present at the base pole of both valves.

SEM observations (Figs 5a-g, 6a-g): The concave $\mathrm{R}$-valves are narrowly clavate to lanceolate (Figs 5a, b). Both poles are narrowly rounded (Figs 5d, f). A distinct pore field on the valve face and mantle is present at the base pole (Fig. 5f); it is formed by densely packed poroids with an irregular shape and usually without regular orientation. The pore field may be clearly differentiated from the transapical striae due to differences in shape and density of poroids. The axial area is moderately wide, gradually widening towards the central area (Figs 5a-c). The central area is narrow, elliptical and slightly wider than the axial area (Figs 5a-c). Internally, the central area is wide taking up almost $1 / 2$ of the valve width (Figs 5e, g). The raphe system is central, curved with a slightly longer raphe branch at the base pole. Externally, the proximal raphe fissures expand into drop-shaped central pores (Figs $5 \mathrm{a}-\mathrm{c})$. Internally, the proximal raphe ends are hook-shaped in the same direction of the external distal raphe fissures (Figs 5e, g). The distal raphe fissure at both the head and base poles are strongly curved and terminate close to the edge of the valve mantle (Figs 5d, f). The raphe fissures on both poles are curved towards the same valve side. Striae in the middle of the valve are equally spaced. The striae are uniseriate, weakly radiate or parallel, and formed by elongated areolae (Figs 5a-d, f). Occasionally, a few striae have two smaller areolae (false biseriate) as on Figs $5 \mathrm{c}, \mathrm{d}$, but this is not a regular feature. The areolae close to the raphe appear smaller and have round or irregularly shaped foramina (Figs 5c, d, f). Internally, areolae have oblong openings (Fig. $5 \mathrm{~g}$ ). The sieve membranes were corroded during the cleaning process. The interstriae (transapical costae) are strongly developed and narrower than the striae (Figs 5e, g).
The convex D-valve is heteropolar, clavate, with narrowly rounded base and head poles (Figs $6 \mathrm{a}-\mathrm{g}$ ). The axial area is moderately wide, gradually expanding towards the valve centre. A reduced raphe system is present at the poles (Figs 6d, f). The raphe branch at the base pole is much longer than that at the head pole (Figs 6d, f). Externally, the raphe branch at the base pole has an expanded and elongated proximal fissure (Fig. 6d). Distally it forms a weak hook extending onto the valve mantle. Internally, the proximal raphe fissure is crook-shaped (Fig. 6e). The distal raphe fissure is usually located under the pseudoseptum and the helictoglossa cannot be seen. A distinct pore field is present at the base pole. It is composed of small, densely packed poroids with oval external openings (Fig. 6d).

The raphe branch at the head pole is slightly expanded at the ends. The proximal raphe fissure terminates in a small pore, while the distal fissure is slightly bent (Fig. 6f). Distally, the raphe terminates just beyond the valve apex, but does not continue onto the mantle. Internally, the proximal raphe fissure is crook-shaped (Fig. 6g). The striae are parallel or slightly convergent near the valve ends (Fig. 6a). The interstriae (transapical costae) are strongly developed and are narrower than the striae (Figs 6c, e, g). The areolae are elliptical to oblong with the same size throughout the whole valve (Figs $6 a, d, f)$.

Main differential characters of $R$. baltica are valve shape, stria density $(15-18$ in $10 \mu \mathrm{m})$ in combination with valve width $(4.5-8 \mu \mathrm{m})$. The shortly protracted and subcapitate base pole is observed only in this species. $R$. tenuis and $R$. marina have similar stria densities. However, $R$. tenuis has linear and narrower valves (width $=$ 3-4.5 $\mu \mathrm{m}$ ), while $R$. marina has broadly clavate and wider valves (width $=8.5-11 \mu \mathrm{m}$ ). $R$. abbreviata has lower stria densities (9-12 in 10 $\mu \mathrm{m})$ and distantly spaced striae at mid-valve. Another taxon, $R$. affinis has lower stria densities $(11-14$ in $10 \mu \mathrm{m})$ and broadly lanceolate valves (Table 3).

Taxonomical notes: The type illustrations presented by SCHUMANN (1867, figs 1a-c) represent initial cells, since the valves and frustule in girdle view are stronly inflated in the mid-valve. Such an initial D-valve is depicted on Fig. 4v. The diminution range for $R$. baltica presented in this study is slightly lower than the valve size given by Schumann (1867, figs 1a-c), because most of the valves present on the observed slide belong to 
vegetative cells. However, the type material for analyses was not available during this study.

Several authors treated this taxon as a variety of $R$. curvata (Cleve-Euler 1953, PANKow 1976) or R. abbreviata (WENDKER 1990, p. 61) or as a synonym of the latter (VANLANDINGHAM 1978). The frustules illustrated in SNoeiss (1993, figs 81 : 1-3), probably belong to $R$. baltica, but cannot be correctly identified since they are lying in girdle view. However, $R$. baltica differs from $R$. abbreviata regarding striae density and ecological preferences.

Ecology: Brackish water species, frequently observed in epiphytic assemblages in the Baltic Sea, where it may be very abundant. It has also been observed in several sandy samples from the Baltic Sea, but always in low abundance. This taxon probably has a wider distribution in brackish waters, but it is often misidentified as $R$. abbreviata or $R$. curvata.

\section{Rhoicosphenia marina (KütZING) M. SCHMIDT (Figs 7a-r)}

Basionym: Gomphonema curvatum var. marinum KüTZING 1844, p. 85, fig. 8: 3.

Nomenclatural synonyms: Gomphonema (?)marinum (KütZing) W. Sмітн 1853, p. 81, pl. 29, fig. 246; Rhoicosphenia curvata var. marina (KüTZING) RABENHORST 1864, p. 113; Rhoicosphenia marina (W. Sмiтн) M. Sснмidt 1899 in Schmidt et al. 1874-1959, fig. 213: 28-34 nom. illegitimate.

LM observations (Figs 7a-r): In girdle view, frustules have a bent wedge shape (Fig. 7a). Valves are heteropolar, clavate, with a broadly to obtusely rounded head pole and attenuate base pole. Valve length varies from 29 to $45 \mu \mathrm{m}$, and valve width is $8.5-11 \mu \mathrm{m}$. Raphe system is differently developed on the two valves. The concave $\mathrm{R}$-valve has a fully developed raphe with large central pores (Figs 7b-i), while the convex D-valve has a reduced raphe system, with short raphe slits lying close to the poles (Figs $7 \mathrm{j}-\mathrm{r}$ ). The axial area on the concave $\mathrm{R}$-valve is very narrow. The central area is weakly expressed, narrowly lanceolate. The axial area on the convex D-valve is narrow and linear. Striae on $\mathrm{R}$-valves are evenly spaced $13-17$ in $10 \mu \mathrm{m}$, and parallel to weakly radiate throughout the whole valve length. The striae on the D-valve are parallel to slightly radiate, 16-20 in $10 \mu \mathrm{m}$. In LM, areolae are hardly visible. A distinct pore field is present at the base pole of both valves.

Taxonomic note: The transfer of
Gomphonema curvata var. marinum into the genus Rhoicosphenia was performed by M. Schmidt in SchmidT et al. (1874-1959). Since the author made an indirect reference to Kützing's basionym when citing W. Smith (1853) who himself cited the correct basionym, the combination made by M. Schmidt is valid.

There are two additional problems concerning this species: figure number and valve shape. KüTZING $(1844$, p. 85$)$ indicates that "Gomphonema curvatum y marinum" is illustrated on "Taf. 9. Fig. III", while in the explanation of plates (op. cit. p. 142), "Gomphonema curvatum" is depicted on Taf. 9, Figs I. II, III. It is assumed that it is just a writing mistake. With respect to the second problem, KüTZING (1844) provided a short description "majus, stipite parum crassiori, subramoso" and did not present a specimen in valve view, but only in girdle view (KüTzING 1844, fig. 8: 3). The first illustration of the valve belonging to this species appeared in SмIтH (1853). According to the description and illustrations provided by SмIтH (1853, p. 81, fig. 29: 246), the valves are broadly clavate with broadly rounded ends, $12.7-53.3 \mu \mathrm{m}$ long with 14 striae in $10 \mu \mathrm{m}$. Similar morphological features have been found during this study and match those of SмIтH (1853) with respect to the valve size, shape and striae density.

The specimens of $R$. marina depicted in CARDINAL et al. (1984, figs 83, 84) are comparable with Schmidt's illustration in SCHMiDT et al. (1874-1959, fig. 213: 32). However, they significantly differ from $R$. marina especially in respect to the shape of central area. The identity of these specimens needs to be verified. The valves of $R$. marina depicted by GÜTTINGER (1991, figs 2.05.40.2) are significantly narrower (width $=$ 5-6.5 $\mu \mathrm{m}$ ) than $R$. marina and appears similar to $R$. omblaensis, especially with respect to stria density, shape of the central area and shape of foramina. It is very likely that those valves belong to $R$. omblaensis.

Main differential characters of $R$. marina are valve shape (broadly clavate), valve width $(8.5-11 \mu \mathrm{m})$ and high stria density (16-20 in 10 $\mu \mathrm{m})$. This species has the broadest valves among Rhoicosphenia taxa. WitKowski et al. (2000, fig. 58: 8-17) illustrated several valves and frustules in girdle view, which are more closely related to $R$. linearis, while the valve illustrated in fig. 58: 18 belongs to $R$. flexa since it is coarsely punctate. It is very likely that the specimens illustrated in 
WitKowski et al. (2000, figs 16,17$)$ belong to $R$. omblaensis (see below).

Ecology: Marine species (Peragallo \& Peragallo 1897-1908), frequently recorded from costal waters in epiphytic (Nagumo \& Tanaka 1994, Mino \& WitKowski 2005), epizoic (Wuchter et al. 2003) or planktonic communities (CARRADA et al. 1981).

\section{Rhoicosphenia linearis ØstruP (Figs 8a-u)}

Rhoicosphenia linearis ØstRUP 1910, p. 120, fig. 3: 74.

LM observations (Figs 8a-u): Frustules in girdle view have a bent wedge shape. The valves are linear to narrowly clavate, valve margins almost parallel in the middle. Head pole more broadly rounded than base pole. Valve length is 35-66 $\mu \mathrm{m}$, valve width 5.5-7 $\mu \mathrm{m}$ (post-initial cell up to $9 \mu \mathrm{m}$ ). The concave R-valve has a fully developed, filiform raphe with large central pores (Figs 8b-1), while the convex D-valve has a reduced raphe system, with short raphe slits lying close to the poles (Figs $8 \mathrm{~m}-\mathrm{u}$ ). The axial area on the concave R-valve is very narrow, and linear. Central area on the $\mathrm{R}$-valve is absent or very narrow, slightly wider than the axial area, with exception in the initial and post-inital cells which have a wide central area relative to the valve width (Figs $8 b, c$ ). The axial area on the convex D-valve is very narrow, almost inconspicuous. Striae on the concave R-valve are densely spaced and distinctly punctate, $13-17$ in $10 \mu \mathrm{m}$, radiate at the center changing to parallel, finally parallel or radiate at the apices. Striae on the D-valve are finely punctate, parallel in the middle and slightly radiate at the ends, $15-17$ in $10 \mu \mathrm{m}$. A pore field is present at the base pole of both valves.

Main differential characters of $R$. linearis are the valve shape (linear with almost parallel valve margins in the mid-valve) and valve width. $R$. linearis can be easily differentiated from $R$. marina by the narrower valves $(5.5-7 \mu \mathrm{m}$ vs. $8.5-11 \mu \mathrm{m}) . R$. baltica has similar valve size and stria density, but it has a different valve outline and shape of base pole.

Ecology: Brackish water species (ØSTRUP 1910) not frequently recorded, probably due to confusion with other species e.g. R. abbreviata or $R$. marina. WitKowski et al. (2000, fig. 58: 1,2$)$ provided two images from the type material, but also have recorded this species from Jutland Bank, North Sea (loc. cit. p. 346). In the type material, $R$. linearis is frequent.

Rhoicosphenia macedonica LeVKov \& KrSTIC (Figs 9a-t, 10a-h, 11 a-g)

Rhoicosphenia macedonica LeVKov \& KRSTIC in LevKov et al. 2007, p. 117, fig. 30: 1-17.

LM observations (Figs 9a-t): Frustules in girdle view have a bent wedge shape (Fig. 9a). The valves are clavate with a broadly rounded head pole and a narrowly rounded base pole. Valve length is $15-52 \mu \mathrm{m}$ and valve width is $5.5-8.5 \mu \mathrm{m}$. The concave R-valve has a fully developed, filiform raphe with large central pores (Figs $10 \mathrm{~b}-\mathrm{j}$ ), while the convex D-valve has a reduced raphe system, with short raphe slits lying close to the poles (Figs $10 \mathrm{k}-\mathrm{t}$ ). The axial area on the concave $\mathrm{R}$-valve is very narrow, and linear. The central area on the $\mathrm{R}$-valve is narrow, elliptical and longitudinally elongated, more expressed in larger specimens, while barely noticeable in smaller specimens. The axial area on the convex D-valve is narrow, clearly visible in larger specimens. Striae on the concave $\mathrm{R}$-valve are densely spaced $18-22$ in $10 \mu \mathrm{m}$, and parallel to weakly radiate throughout the whole valve length. Striae on the convex D-valve are parallel in the middle, becoming slightly radiate at the ends, 22-24 in $10 \mu \mathrm{m}$. In LM, both R- and D- valves have distinct areolae. Pore fields are present at the base pole of both valves.

SEM observations (Figs 10a- $\mathrm{h}, 11 \mathrm{a}-\mathrm{g}$ ): Frustules in girdle view are bent and wedgeshaped (Fig. 10a). The cingulum on both thecae comprises three open bands, each copula bearing a single row of poroids on the pars exterior. The concave $\mathrm{R}$-valve is heteropolar with a narrow to rounded head pole and a narrowly rounded base pole (Figs $10 \mathrm{~b}, \mathrm{~h}$ ). The axial area is very narrow and linear (Figs 10b, d). Externally the central area is narrow, while internally it is large occupying almost $1 / 3$ of the valve width (Figs 10b, d). The raphe system is central. Externally, the proximal raphe fissures are expanded and drop-shaped (Fig. 10d), while internally they are crook-shaped (Fig. 10e). The distal raphe fissure on the head pole is doubly curved and expands close to the base of the valve mantle. A very small hyaline area is present on both sides of the raphe fissure (Fig. 10g). The distal raphe fissure at the base pole passes onto the valve mantle and terminates close to the base of the mantle (Fig. 10h). The striae are slightly radiate in the middle, becoming parallel towards the poles (Figs 10b, h). Each stria comprises a row 
of simple areolae. The areolae are small, densely spaced with elliptical to oblong foramina (Figs $10 \mathrm{~b}, \mathrm{~d})$. The areolae at the head pole have unique cribrum-like occlusions (Fig. 10g). Internally, they have round to elliptical openings (Figs 10c, e). The interstriae are narrow, strongly developed giving a chambered appearance to the areolae (Figs 10c, e). Close to the base pole, a pore field with densely packed areolae is present. There is no clear distinction between the pore field and the transapical striae (Fig. 10h).

The convex D-valve (Figs 11a-g) has a strongly reduced raphe system as in other Rhoicosphenia species. The raphe branch on the base pole has expanded drop-shaped, proximal fissures (Fig. 11d), while internally the proximal raphe fissures are crook-shaped (Fig. 11f). Distally the raphe continues onto the valve mantle and divides the apical pore field in two halves (Fig. 11d).

The raphe branch on the head pole is a linear or weakly arched, short slit (Fig. 11e). The proximal raphe fissure is weakly expanded into a proximal pore, while internally it is slightly bent (Fig. 11g). The striae are uniseriate and composed of simple, longitudinally elongated areolae. Each areola has a linear ellipical foramina and recessed occluded plate (Figs 11a, b, e). The striae are densely spaced, internally separated by very narrow interstriae (Figs 11c, f, g).

Taxonomic note: The specimens presented in this study are, in general, larger than specimens presented in the type description (LevKov et al. 2007, figs 30: 1-17). In the type material only small sized valves and intial cells are present. In this study several other samples from Lake Ohrid were observed in order to characterize the whole diminution series, and the variability in morphological features.

Main differential characters of $R$. macedonica are the valve shape (broadly clavate) and high stria density on the D-valve (22-24 in $10 \mu \mathrm{m})$. These two features easily differentiate this species from other freshwater taxa of the genus. Rhoicosphenia macedonica can be easily differentiated from $R$. abbreviata by the valve shape and width, striae density (compare Figs $2 \mathrm{~h}-\mathrm{p}$ with $9 \mathrm{k}-\mathrm{t})$ as well as areolae shape and structure (compare Fig. 2f with Fig. 10g).

Ecology: This species has so far been observed only in Lake Ohrid, Macedonia. It is a deep, ancient, oligotrophic, slightly alkaline lake. $R$. macedonica has been frequently observed attached to reeds or other macrophytes close to the lake shore (depth up to $0.5 \mathrm{~m}$ ). Higher abundance has been recorded during the summer period. So far it has not been observed in the sister lake, Lake Prespa, which is mesotrophic to slightly eutrophic (LeVKov et al. 2007).

\section{Rhoicosphenia tenuis Levkov et Nakov (Figs 12a-x, 13a-g, 14a-g) \\ Rhoicosphenia tenuis Levkov \& NAKov 2008, p. 379, figs $1-14,30-49$.}

LM observations (Figs 12a-x): Frustules in girdle view have a bent wedge shape (Fig. 12b), except initial cells, which are more or less isopolar (Fig. 12a). Valves are heteropolar, narrowly linear, with an obtuse head pole and a narrowly rounded base pole. Valve length varies from 15 to $60 \mu \mathrm{m}$, and valve width from 3 to $5 \mu \mathrm{m}$. Concave $\mathrm{R}-$ valve has a well-developed filiform raphe with large central pores (Figs 12c-1), while the convex D-valve has a reduced raphe system, with short raphe slits lying close to the poles (Figs $12 \mathrm{~m}-\mathrm{x}$ ). The axial area on the $\mathrm{R}-\mathrm{valve}$ is lanceolate, narrow and the central area is either absent or weakly expressed. Striae on the R-valve are parallel in the middle, becoming slightly radiate at the ends, $12-16$ in 10 $\mu \mathrm{m}$, while stria density in the D-valve is $13-17$ in $10 \mu \mathrm{m}$. A pore field is present at the base pole of both valves.

SEM observations (Figs 13a-g, 14a-g): In girdle view, frustules have a bent wedge shape (Fig. 13a). The cingulum on both thecae is composed of two open bands, each bearing a single row of poroids with simple openings externally (Figs 13a, 14a) which are occluded internally (Fig. 13d). The external openings of the poroids are round, while the internal openings are elliptical (Fig. 13d). The concave R-valve is narrow, sublinear and heteropolar (Figs 13b, c). The head pole is obtusely rounded (Fig. 13f) and the base pole is narrowly rounded (Fig. 13e). The axial area is narrow, tapering towards the valve ends. The central area is usually not well developed and cannot be separated from the axial area. Striae at the valve centre are usually slightly shorter than the rest. The raphe system is central with a slightly longer raphe branch at the base pole. The external central raphe fissures are expanded into the central pores and are drop-shaped (Figs 13b, c) while internally they are crook-shaped (Fig. $13 \mathrm{~g}$ ). The terminal raphe fissures at both poles are doubly curved and terminate close to the edge of 
the valve mantle (Figs 13e, f). The curvature of the distal raphe fissure at the head pole is more expressed. Striae are parallel in the valve centre and become slightly radiate towards the poles, where they are more densely spaced (Figs 13b, c). The interstriae (transapical costae) are strongly developed giving a chambered appearance to the areolae (Figs 13d, g). Each stria comprises a row of simple areolae. The external foramina of each stria close to the valve centre are round, becoming longitudinally elongated towards the valve ends and valve margin (Figs 13b, c, e, f). Similary as above mentioned Rhoicosphenia species there is a recessed occlusion within each areola (Fig. 13f). Internally, areolae have round openings and are occluded with sieve membranes (Figs 13d, g). A small, unilateral hyaline area is present at the head and base pole (Figs 13e, f). A pore field is present close to the base pole. It is formed by densely packed areolae with an oblique orientation (Fig. 13e). There is no clear distinction between the pore field and the transapical striae.

The convex D-valve has a strongly reduced raphe system (Figs 14a-g). The raphe branch at the base pole is much longer than the raphe branch at the head pole (Figs 14b, c, d). Externally, the raphe branch at the base pole has an expanded drop-shaped proximal fissure (Fig. 14c), while internally the proximal raphe fissure is crookshaped (Fig. 14g). The distal raphe fissure at the head pole does not extend onto the valve mantle and terminates just beyond the valve apex (Fig. 14d). Proximally the terminal fissure on the head pole is slightly expanded into an inconspicuous pore (Fig. 14d), while internally it is only slightly bent (Fig. 14f). The striae are uniseriate, parallel throughout the whole valve length or weakly radiate near the head pole (Figs 14a, b, e). The interstriae (transapical costae) are strongly developed, and equal in width to the striae (Figs $14 \mathrm{e}, \mathrm{f})$. The external foramina are round and become slightly longitudinally elongated towards the poles (Figs 14c, d). Internally, the areolae are round and covered by sieve membranes (Figs 14e, f). A pore field is present on the base pole, formed by densely spaced and obliquely orientated poroids (Fig. 14c).

Main differential characters of $R$. tenuis are the valve shape (narrow linear), valve width (3-4.5 $\mu \mathrm{m})$ and stria density on the D-valve (13-17 in $10 \mu \mathrm{m}) . R$. tenuis closely resembles $R$. baicalensis SKaBitCheWsKIJ, but differences may be observed in the stria density on the D-valve (10-12 in 10 $\mu \mathrm{m}$ in $R$. baicalensis). From other freshwater representatives of the genus Rhoicosphenia, it can be easily differentiated by shape and valve width.

Ecology: R. tenuis has so far been observed in epiphytic diatom assemblages from Lake Ohrid, Macedonia. It is frequently observed attached to different macrophytes in St. Naum springs. These springs are typical oligotrophic habitats with more or less constant physico-chemical parameters. The variation of water temperature, $\mathrm{pH}$ and content of nutrients during the year is very low. In general, a higher abundance of this taxon has been recorded in early spring, but it also may be found throughout the whole year.

\section{Rhoicosphenia baicalensis SKABITCHEWSKIJ} (Figs 15a-y, 16a-h, 17a-g)

Rhoicosphenia baicalensis SKABITCHEWSKIJ 1976, p. 269, fig. 1: 7-10.

Synonym: Rhoicosphenia curvata var. baicalensis SkVORTZOw \& MeYer 1928, p. 32, fig. 3: 150.

LM observations (Figs 15a-y): Frustules in girdle view have a bent wedge shape (Figs 15a, b). Valves are heteropolar, narrow and linear, with narrowly rounded head and base poles. Valve length varies from 16 to 49 (?62.9) $\mu \mathrm{m}$, and valve width 3.5 to $5.2(? 6.8) \mu \mathrm{m}$. The concave $\mathrm{R}$-valve has a well-developed filiform raphe with large central pores (Figs $15 \mathrm{c}-\mathrm{m}$ ), while the convex valve has a reduced raphe system, with short raphe slits lying close to the poles (Figs 15n-y). The axial area on the $\mathrm{R}$-valve is lanceolate, and very narrow. The central area is absent or weakly expressed. Striae on the $\mathrm{R}$-valve are parallel in the middle becoming slightly radiate towards the ends, 9-12 in $10 \mu \mathrm{m}$ (up to 14 in post initial cell, Fig. 15c), while stria density in the D-valve is $10-12$ in $10 \mu \mathrm{m}$. A pore field is present at the base pole of both valves.

SEM observations (Figs 16a-h, 17a-g): Frustules in girdle view have a strongly bent wedge shape (Fig. 16a). The cingulum is composed of three open bands, each bearing a single row of poroids with simple round external openings. The concave $\mathrm{R}$-valve is narrow, sublinear and heteropolar (Figs 16b, c). Both the head and base pole are narrowly rounded (Figs 16f, g). The axial area is narrow and lanceolate. The central area is not well developed and can be hardly differentiated from the axial area (Figs 16c, d). Striae at the valve centre are usually slightly shorter than the rest of the striae (Fig. 16d). The raphe system is central with a slightly longer raphe branch at the 
base pole. The external central raphe fissures are drop-shaped pores (Figs 16c, d), while internally they are crook-shaped (Fig. 16h). The terminal raphe fissures at both poles are doubly curved and terminate close to the edge of the valve mantle (Figs 16f, g). The raphe fissures at both poles are curved towards the same valve side. Striae are parallel in the valve centre and become slightly radiate towards the poles. Striae near the head pole are more densely spaced (Figs 16a, f). The interstriae (transapical costae) are strongly developed giving a chambered appearance to the areolae (Fig. 16e). Interstriae in the valve middle are much wider than the striae (Figs 16e, h). Each stria comprises a row of simple, round areolae. The external foramina of areolae close to the valve centre are round, becoming elliptical towards the valve ends and valve margin (Figs 16d, f). Internally, areolae have round openings. The sieve membranes were not observed (Fig. 16h), probably being corroded during the cleaning process. A pore field is present close to the base pole. It is formed by densely packed areolae with oblique orientation (Fig. 16g). There is no clear distinction between the pore field and transapical striae.

The convex D-valve has a strongly reduced raphe system (Figs 17a-g). Externally, the raphe branch at the base pole has an expanded dropshaped proximal pore (Figs 17a, b, d), while internally the proximal raphe fissure is tightly crook-shaped (Fig. 17e). The raphe branch at the base pole is longer than that at the head pole (Figs 17d, f). The distal raphe fissure at the head pole does not extend onto the valve mantle and terminates just beyond the valve apex (Fig. 17f). Proximally the raphe branch terminates with a distinct proximal pore, while internally it is linear and not bent (Fig. 17g). The striae are uniseriate, parallel throughout the whole valve length (Figs $17 \mathrm{a}, \mathrm{b}$ ). The interstriae (transapical costae) are strongly developed (Fig. 17c) and are much wider than the striae. The areolae have round external and internal openings (Figs 17a-c, g), and internally are covered by sieve membranes (Fig. 17c). The size and shape of the areolae are constant, not increasing towards the valve mantle or poles. A pore field is present on the base pole, formed by densely spaced and obliquely orientated poroids (Fig. 17d).

Maindifferential characters of $R$. baicalensis are valve width and stria density. A similar species is $R$. tenuis, but the latter has a higher striae density (13-17 in $10 \mu \mathrm{m})$. In addition, striae in the valve middle are more distantly spaced in $R$. baicalensis, and consequently the interstriae are much wider (compare Fig. 17c with Fig. 14e).

Taxonomical notes: $R$. curvata var. baicalensis (SKVORTZOW \& MEYER 1928, p. 32, fig. 3: 150) is another taxon of this genus that has been described from Lake Baikal. According to the protologue the valve is larger (length $=62.9$ $\mu \mathrm{m}$, width $=6.8 \mu \mathrm{m}$ ) and has a higher stria density (14 in $10 \mu \mathrm{m})$ compared with $R$. baicalensis. Nevertheless, the illustrated type specimen (op. cit. fig. 3: 150) shows only the valve shape and presence of pseudoseptum, without any additional valve features. Valves with these numerical features were not observed during this study, although we analyzed samples collected by SkvorTzow. It is likely that the depicted valve and protologue given by SKVORTzow \& Meyer (1928) refer to an initial cell. This last observation is supported by the post-initial cell observed in this study with a valve width of $6.2 \mu \mathrm{m}$ and stria density around 14 in $10 \mu \mathrm{m}$.

An additional problem considering $R$. baicalensis is stria density on the $\mathrm{R}$-valve. According to SKABITCHEWSKIJ (1976, p. 269) the $\mathrm{R}$-valve should have 7-10 striae in $10 \mu \mathrm{m}$, while two illustrated valves (SKABITCHEWSKIJ 1976, figs $7,8)$ have 12 striae in $10 \mu \mathrm{m}$, which is closer to our observations. The numerical features of the illustrated type specimens are in agreement with these observations, while valves with lower stria density (below 9 striae in $10 \mu \mathrm{m}$ ) were not observed during this study.

Ecology: So far this species has been observed only in Lake Baikal. It has not been recorded during this study from other ancient lakes (e.g. Teletskoye, Utkul and Hövsgöl lakes).

\section{Rhoicosphenia flexa GifFen (Figs 18a-w, 19a-f, 20a-g) \\ Rhoicosphenia flexa GifFen 1970, p. 96, fig. 2: 55-58.}

LM observations (Figs 18a-w): In girdle view, frustules have a bent wedge shape (Fig. 18a). Valves are heteropolar, subclavate to sublinear with a broadly to narrowly rounded head pole and attenuate base pole. Valve length varies from 23 to $55 \mu \mathrm{m}$, and valve width is $4.5-7.5 \mu \mathrm{m}$. The concave R-valve has a fully developed raphe with large central pores (Figs 18b-k), while the convex D-valve has a reduced raphe system, with a short raphe slit lying close to the base pole. The raphe 
slit on the head pole is absent (Figs 181-w). The axial area on the concave $\mathrm{R}-$ valve is very narrow and linear. The central area is weakly expressed, narrowly elliptical and longitudinally elongated, slightly wider than the axial area. The axial area on the convex D-valve is very narrow, and linear. Striae on both valves are coarsely punctate, 11-15 in $10 \mu \mathrm{m}$, weakly radiate in the middle becoming parallel towards the valve ends. Pore fields are present at the base pole of both valves.

SEM observations (Figs 19a-f, 20a-g): Frustules in girdle view have a bent wedge shape (Fig. 19a). The cingulum of each thecae is composed of three open bands, each bearing a single row of poroids with simple round external openings (Fig. 19a). The concave $\mathrm{R}$-valve is narrowly clavate and heteropolar (Figs 19b, c). Both the head and base pole are narrowly rounded (Figs 19b, c, e). The axial area is very narrow and linear. The central area is not well expressed and it is slightly wider than the axial area. The raphe system is central with a slightly longer raphe branch at the base pole. The external central raphe fissures expand into central pores and are drop-shaped (Figs 19b, c) while internally they are crook-shaped (Fig. 19d). The terminal raphe fissures on both poles are weakly curved and terminate close to the edge of the valve mantle (Figs 19b, e). The raphe fissures at both poles are curved on the same valve side. The striae are slightly radiate and composed of circular areolae (Figs 19b, c, e). The interstriae (transapical costae) are strongly developed giving a chambered appearance to the areolae (Figs 19d, f). Interstriae at the mid-valve are equal in width to the striae. Each stria comprises a row of simple areolae. Internally, the areolae have round openings (Fig. 19f). A pore field is present close to the base pole. It is formed by densely packed circular poroids (Fig. 19b). There is no clear distinction between the pore field and the transapical striae.

The convex D-valve has a strongly reduced raphe system (Figs 20a-g). The raphe slit is present on the base pole, and absent at the head pole (Figs b-e). Externally, the raphe branch at the base pole has an expanded drop-shaped proximal fissure (Figs 20f, g), while internally the raphe fissure is crook-shaped (not illustrated). The axial area is very narrow and linear. A small hyaline area is present around the proximal raphe fissure on the base pole (Fig. 20b). The striae are uniseriate, parallel in the middle, becoming weakly radiate towards the head pole (Figs 20a, b, d). The interstriae are strongly developed. The areolae have round external and internal openings (Figs 20d, e). A pore field is present on the base pole formed by densely spaced circular poroids (Fig. 20f).

Main differential characters of R. flexa are absence of raphe branch on head pole of D-valve as well as the coarsely punctate striae.

Ecology: Rhoicosphenia flexa has been observed in many brackish and marine habitats in South Africa where it can be very frequent. Other records of this species have not been found.

\section{Rhoicosphenia genuflexa (KüTZING) MeduIN (Figs 21a-ab)}

Basionym: Navicula(?) genuflexa KüTZING 1844, p. 101, fig. 21: 6.

Rhoicosphenia genuflexa (KützING) MEdLIN in MedLIN \& FRYXELL 1984a, p. 257, figs 1-5.

LM observations (Figs 21a-ab): In girdle view the frustules are isopolar and bent (Figs 21a, b). The valves are isopolar, linear with obtusely rounded poles. Valve length varies from 6 to $40 \mu \mathrm{m}$, and valve width is $3-5 \mu \mathrm{m}$. The concave $\mathrm{R}-\mathrm{valve}$ has a fully developed raphe with large central pores (Figs $21 \mathrm{c}-\mathrm{m}$ ), while the convex D-valve has a reduced raphe system, with short raphe slits lying close to the poles (Figs 21n-ab). The axial area on the concave $\mathrm{R}$-valve is very narrow. The central area is a large fascia extending to the valve margin. The axial area on the convex D-valve is narrow and linear. Striae on $\mathrm{R}-\mathrm{valves}$ are radiate, $14-17$ in $10 \mu \mathrm{m}$. Striae on D-valve are parallel in the valve middle, $11-17$ in $10 \mu \mathrm{m}$, becoming weakly radiate and more densely spaced towards the valve ends. A distinct pore field is present at the base pole of the $\mathrm{R}$-valve. A pore field on the D-valve is absent.

Main differential characters of $R$. genuflexa are valve shape (isopolar linear) and absence of a pore field on the convex D-valve.

Ecology: Marine species, frequently recorded in coastal waters attached to different macrophytes. It has been observed in tropical seas (Giffen 1970, 1973; Medlin \& Fryxell 1984a; Argumedo Hernández \& Sigueiros Beltrones 2008), Baltic Sea (Witkowski et al. 2000), St Lawrence estuary North America (CARDINAL et al. 1984) and Antarctica (AL-Handal \& WulfF 2008). 
Rhoicosphenia lacustris Levkov sp. nov. (Figs 22a-x, 23a-h, 24a-h)

Diagnosis: Frustula dorsiventralia et heteropolaria. Valvae heteropolares, late clavatae verticibus obtusate rotundatis (quoad specimina maiora) ad cuneatis (quoad specimina minora) et polis basalibus angustis rotundatis. Longitudo 25$62 \mu \mathrm{m}$, latitudo 6-9 $\mu \mathrm{m}$. Ad apices pseudoseptum distinctum adest. Valva concava raphe filiforme et poris centralibus distinctis, area axiali angusta gradatim dilatata, area centrali parva, lanceolata vel elliptica, striis transapicalibus radiantibus 1315 in $10 \mu \mathrm{m}$. Valva convexa raphe reducta curtis fissuris positis ad apices, striis transapicalibus subparallelis in media parte vel minus radiantibus ad apices, 11-15 in $10 \mu \mathrm{m}$. Area porellorum poli basalis distincta.

Description (Figs 22a-x): In girdle view frustules wedge shape and weakly bent (Fig. 22a). Valves heteropolar, broadly clavate with obtusely rounded (in larger specimens) to cuneate (in smaller specimens) head pole, and narrowly rounded base pole. Valves $25-62 \mu \mathrm{m}$ long, $6-9 \mu \mathrm{m}$ wide. Pseudoseptum present on poles. Raphe system differently developed on both valves. Concave valve with well-developed filiform raphe and large central pores (Figs 22b-1), while convex valve with reduced raphe system, and short raphe slits close to poles (Figs 22m-x). Axial area on concave R-valve narrow, wide near central area. Central area narrow, lanceolate to elliptical. Axial area on D-valve wide, tapering towards apices. Striae on $\mathrm{R}$-valve radiate in middle, more radiate towards ends, $13-15$ in $10 \mu \mathrm{m}$. Striae on D-valve subparallel to slightly radiate near poles, and densely spaced, $11-15$ in $10 \mu \mathrm{m}$. Pore field at the base pole of both valves.

SEM observations (Figs 23a-h, 24a-h): In girdle view, frustules have a bent wedge shape (Fig. 23a). The cingulum is composed of two open bands, each bearing a single row of poroids. The poroids are round, becoming elongated near the head pole. The valvocopula is modified with terminal slits and interlocks with each pseudosepta (Fig. 23d). The concave $\mathrm{R}$-valve is heteropolar with an obtusely rounded head pole and a narrowly rounded base pole (Figs 23b, c). The axial area is narrow, gradually expanding towards the middle of the valve (Fig. 23h). The central area is narrow, elliptical to lanceolate and longitudinally elongate. The raphe system is central. The two raphe slits of the $\mathrm{R}-\mathrm{valve}$ have different length, while the raphe branch at the base pole is slightly longer. Externally, the central raphe fissures are expanded and drop-shaped (Fig. 23h), while they are crook-shaped inside (Figs 23d, e).

The terminal fissure at the head pole is doubly curved and terminates close to the edge of the valve mantle (Fig. 23g). The terminal raphe fissure on the base pole is strongly curved and divides the apical pore field in two parts. The striae are subparallel throughout (Figs 23b, c). Each stria comprises a row of simple areolae. The areolae are longitudinally elongated with narrow external foramina. Silica nodular intersections in the areolae near the head pole are present, causing the areolae to be intersected into smaller openings (Fig. 23g).

The areola length increases towards the head pole (Fig. 23a). Internally the areolae have wider oblong openings (Fig. 23e). The interstriae are strongly developed giving a chambered appearance to the areolae and are wider than the interstriae (Figs 23d, e). Close to the base pole, a pore field with densely packed areolae is present. A clear distinction between the pore field and transapical striae can be noticed (Fig. 23f). Pores within the pore field appear round and orientated in longitudinal rows.

The convex D-valve (Figs 24a-h) has a strongly reduced raphe system (Figs 24a-d). The axial area is moderately wide externally (Figs $24 \mathrm{a}, \mathrm{d}$ ), while internally it is wider, and gradually narrowing towards the poles. The raphe branch on the head pole is a short slit distally slightly bent, while proximally expanded into a small proximal pore (Fig. 24e). Internally the proximal raphe fissure is only slightly bent (Fig. 24f). The raphe branch on the base pole has an expanded dropshaped proximal fissure (Fig. 24f), while internally it is crook-shaped (Fig. 24g). Distally, the raphe continues on the valve mantle and divides the apical pore field. Internally, the distal fissure forms a small helictoglossa. The striae are uniseriate composed of simple, longitudinally elongated and densely spaced areolae (Figs 24a, d). The recessed sieve plate is visible from the external view. Striae at the center of the valve are equally positioned, not distantly spaced as in $R$. abbreviata (compare Fig. 24a with Fig. 3a). Externally, the interstriae appear narrower than the striae (Figs 24a, d, e), while internally they are almost as broad as the striae (Figs 24b, c). 
Holotype: Designated here Slide 2088 in MKDNC, specimen representing the holotype is Fig. 22v. Isotype: Slide ZU7/17 in BRM.

Type locality: Lake Dojran, Nov Dojran, Macedonia.

Type material: Macrophytes, collection date: 06.05.2000. Accession No. MKDNC 002088. Collected by Z. Levkov

Main differential characters of $R$. lacustris are valve width (consistently wider than $R$. abbreviata), stria density (higher stria density than $R$. abbreviata), valve shape (clavate) and shape of the head pole (not protracted and obtusely rounded). From $R$. abbreviata it can be differentiated by the valve shape and stria density. The differences in stria density between two populations of $R$. abbreviata sensu lato from Vardar River and Lake Doiran were also noticed by LEVKOV \& NAKOV (2008). The population of $R$. abbreviata sensu stricto, which originates from the Vardar River always has a lower stria density (below 12 striae in $10 \mu \mathrm{m}$ ) while the population from Lake Dojran has a consistently higher stria density. Additionally, the valves of $R$. abbreviata sensu stricto are consistently narrower than $R$. lacustris. From R. linearis (Figs 8a-u), R. lacustris can be differentiated by the valve shape (linear to narrowly clavate in $R$. linearis), central area (not differentiated in $R$. linearis) and stria density (15-17 in $10 \mu \mathrm{m}$ in $R$. linearis). Rhoicosphenia marina (Figs $7 \mathrm{a}-\mathrm{r}$ ) has broadly clavate valves (width $=8.5-11 \mu \mathrm{m}$ ) with a higher stria density (16-20 in $10 \mu \mathrm{m}$ in R. marina). Rhoicosphenia baltica (Figs $4 \mathrm{c}-\mathrm{v}$ ) has a narrowly rounded head pole, a subcapitate base pole and higher stria density (15-18 in $10 \mu \mathrm{m})$.

Ecology: Freshwater to brackish water species frequent in eutrophic, hypereutrophic to slightly brackish waters. In the type locality (Lake Doiran), it is very abundant in epiphytic assemblages. The type locality is a shallow, alkaline and eutrophic to hypereutrophic lake (Levkov \& Stojanovski 2001).

\section{Rhoicosphenia affinis LevKov sp. nov. (Figs 25a-s, 26a-h, 27a-f)}

Diagnosis: Frustula dorsiventralia et heteropolaria. Valvae heteropolares, late lanceolatae ad clavatae verticibus attenuatis vel subprotractis et polis basalibus angustis rotundatis. Longitudo 34-65 $\mu \mathrm{m}$, latitudo 6.5-8.5 $\mu \mathrm{m}$. Ad apices pseudoseptum distinctum adest. Valva concava raphe filiforme et poris centralibus distinctis, area axiali angusta gradatim dilatata, area centrali parva, lanceolata, striis transapicalibus parallelis vel minus radiantibus ad apices 11-14 in $10 \mu \mathrm{m}$. Valva convexa raphe reducta curtis fissuris positis ad apices, striis transapicalibus parallelis in media parte vel minus radiantibus ad apices, 11-14 in $10 \mu \mathrm{m}$. Area porellorum poli basalis distincta.

Description (Figs 25a-s): In girdle view frustules wedge-shaped and weakly bent (Figs 25a, b). Valves heteropolar, broadly lanceolate to subclavate, with attenuate and subprotracted head pole and narrowly rounded base pole. Valves 34 $65 \mu \mathrm{m}$ long, and 6.5-8.5 $\mu \mathrm{m}$ wide. Raphe system differently developed on the two valves. Concave valve with well-developed filiform raphe and large central pores (Figs $25 \mathrm{c}-\mathrm{j}$ ). Convex valve with reduced raphe system, and short raphe slits lying close to poles (Figs 25k-s). Axial area on concave $\mathrm{R}$-valve narrow, gradually widening towards central area. Central area lanceolate, slightly wider than axial area. Striae on both valves slightly radiate throughout $11-14$ in $10 \mu \mathrm{m}$. Striae on convex D-valve finely punctate, areolae of striae on concave $\mathrm{R}$-valve not discernable. Pore field at the base pole of both valves.

SEM observations (Figs 26a-h, 27a-f): Frustules in girdle view are wedge-shaped and slightly bent (Fig. 26a). The cingulum comprises three open bands, each bearing a single row of poroids (Fig. 26a) with simple openings externally and internally occluded (Fig. 26d). The external and internal openings of the poroids are round. The concave $\mathrm{R}$-valves are broadly clavate with the widest part in the upper half of the valve (Figs $26 \mathrm{~b}, \mathrm{c})$. The head pole is narrowly to obtusely rounded and in smaller specimens subprotracted (Fig. 26c). The base pole is narrowly rounded. A distinct pore field is present at the base pole. It is formed by densely packed poroids with a round shape (Fig. 26f). A clear distinction between the pore field and the transapical striae can be noticed. The axial area is moderately wide, gradually expanding towards the central area (Figs 26b, c, e). The central area is slightly wider than the axial area. It is more expressed at the primary valve side opposite to the Voigt fault (Fig. 26c). The raphe system is central with a slightly longer raphe branch at the base pole. Externally, the proximal raphe fissures are expanded into the drop-shaped 
central pores (Figs 26b, c, e). Internally they are crook-shaped towards the primary side (Figs $26 \mathrm{~d}, \mathrm{~h})$. The terminal raphe fissures at both the base and head pole are strongly, doubly curved and terminate close to the edge of valve mantle (Figs 26f, g). The raphe fissures on both poles are curved to the secondary valve side. Striae around the central area are equally spaced (more distantly spaced striae around the central area are not present as in $R$. abbreviata). The striae are uniseriate, weakly radiate, and comprise relatively small, oblong areolae (Figs 26b, c, e). Size of each areola increases towards the valve mantle, where foramina are shaped as elongated slits (Fig. 26e). Areolae along the axial area are wider and have round to semi-elliptical foramina (Figs 26c, e). Internally, the areolae have elliptical to oblong openings (Figs 26d, h). The sieve membranes were corroded during the cleaning process. The interstriae (transapical costae) are strongly developed and are narrower than the striae.

The convex D-valve is heteropolar with narrowly rounded base and head pole (Figs 27a, c, d). A distinct pore field is present at the base pole. It is composed of small, densely packed poroids with oval external openings (Fig. 27c). The axial area is narrow and equal in width throughout the length of the valve (Fig. 27a). A strongly reduced raphe system is present. The raphe branch at the base pole is slightly longer than that at the head pole (Figs 27c, d). Externally, the raphe branch at the base pole has expanded and elongated proximal fissures (Fig. 27c). Internally, the proximal raphe fissure is crook-shaped (Fig. 27f). The proximal and distal raphe fissures on the raphe branch at the head pole are slightly bent to the same side (Fig. 27a). Proximally, the raphe terminates with an elongated and slightly expanded pore. Distally, the raphe does not extend onto the valve mantle and terminates just beyond the valve apex (Fig. 27d). Internally, the proximal raphe fissure is slightly expanded and bent (Fig. 27e). Striae are parallel throughout the valve length (Fig. 27a). The interstriae (transapical costae) are strongly developed (Figs 27b, e, f) and are slightly wider than the striae. The foramina are elliptical becoming more elongated near the base and head poles (Figs 27c, d).

Holotype: Designated here slide 065/19 in BRM, specimen representing the holotype is Fig. $25 \mathrm{~g}$.

Isotype: Slide 065/20-21 in BRM.

Type locality: Hai Nan China.

Type material: Hai Nan China, c. Accession No.

\section{$\mathrm{AS} 15 \mathrm{c}$ in BRM.}

Main differential characters of $R$. affinis are the valve shape lanceolate to subclavate, frustule are weakly bent wedge-shape, and have a narrowly rounded head pole. It can be differentiated from $R$. abbreviata by valve and frustule shape. In $R$. abbreviata the mid-valve striae are more distantly spaced, while this feature was not observed in $R$. affinis (compare Fig. 2c with Fig. 26b for R-valve, and Fig. 3a with Fig. 27a for D-valves). In SEM both species can be distinguished by the shape of the areolae, pores and pore fields (compare Fig. $3 \mathrm{c}$ with Fig. 27c). The new species can be easily differentiated from $R$. macedonica by the lower stria density (18-22 in $10 \mu \mathrm{m}$ in R. macedonica).

Ecology: Rhoicosphenia affinis has so far been observed in several samples from eutrophic waters from China, where it is abundant. Further investigations are necessary in order to establish the ecological and biogeographical limits for this species.

\section{Rhoicosphenia fracta (Schumann) De Toni (Figs 28a-ae, 29a-f, 30a-g) \\ Rhoicosphenia fracta (Schumann) De Toni 1891, Sylloge Algarum 2, p. 438. \\ Basionym: Gomphonema fractum SchUmann 1862, Schriften der Königlichen Physikalisch-Ökonomischen Gesellschaft zu Königsberg 3, p. 187; fig. 9: 32. \\ Nomenclatural synonym: Rhoicosphenia curvata var. fracta (SchumanN) Cleve 1895, p. 166.}

LM observations (Figs 28a-ac): In girdle view frustules are wedge-shaped and weakly bent (Figs 28b, c), except the post-initial cells which appear isopolar in girdle view (Fig. 28a). Valves are heteropolar, linear to narrowly lanceolate and subclavate, with a narrowly rounded head and base pole (Figs $28 \mathrm{~d}-\mathrm{u}$ ). Valve length varies from 18.5 to $48.5 \mu \mathrm{m}$ and valve width is between 4 and $5.5 \mu \mathrm{m}$. The raphe system is differently developed on the two valves. Concave valve have a welldeveloped filiform raphe with large central pores (Figs 28d-u), and the convex valve has a reduced raphe system consisting of short slits lying close to the poles (Figs $28 \mathrm{v}-\mathrm{ac}$ ). The axial area on the concave $\mathrm{R}$-valve is narrow, and linear. The central area is absent to very narrow, lanceolate, slightly wider than the axial area. Striae on the $\mathrm{R}$-valve are slightly radiate throughout, $8-15$ in $10 \mu \mathrm{m}$. Striae on the convex D-valve are subparallel, not punctate, $10-12$ in $10 \mu \mathrm{m}$. Pore fields are present at the base pole of both valves. 
SEM observations (Figs 29a-f, 30a-g): Frustules in girdle view are wedge-shaped and slightly bent (Figs 29a, b). The cingulum comprises three open bands, each bearing a single row of round poroids (Figs 29a, b, e). The concave $\mathrm{R}$-valves are narrowly clavate with the widest part in the middle of the valve (Figs 29c, d). Both the head and the base pole are narrowly rounded (Figs 29d, e). A distinct pore field is present at the base pole (Fig. 29e). It is formed by densely packed round poroids, oblique in orientation. A clear distinction between the pore field and the transapical striae can be noticed (Fig. $29 \mathrm{e})$. The axial area is narrow, with almost equal width throughout the whole valve length. The central area is slightly wider than the axial area. The raphe system is central with raphe branches almost equal in length. Externally, the proximal raphe fissures are expanded into the drop-shaped central pores (Fig. 29c). Internally they are crookshaped (Figs 29d, f). The terminal raphe fissures at the base and head pole (not illustrated) are strongly doubly curved and terminate near the edge of valve mantle (Fig. 29e). Raphe fissures on both poles are curved to the same valve side (not illustrated). Striae in the middle of the valve are more distantly spaced (Figs 29c, d). The striae are uniseriate, weakly radiate, comprising small, round to elliptical areolae (Figs 29b, c, e). In corroded specimens, the areolae might be more elongated, as in case of the frustule in girdle view illustrated on Fig. 29a. Areola size increases towards the head pole (Fig. 29c). Internally, areolae have round to oblong openings and are occluded by sieve membranes (Fig. 29f). The size of the internal areola foramina increases towards the valve mantle, where the foramina are more elongated. The interstriae (transapical costae) are strongly developed and much wider than the striae (Figs 29d, f).

The convex D-valve is heteropolar with narrowly rounded base and head poles (Figs 30a, $\mathrm{b}, \mathrm{d})$. A distinct pore field is present at the base pole. It is composed of small, densely packed poroids with oval external openings (Fig. 30c). The axial area is narrow, and slightly wider at mid-valve (Figs 30a, d). A strongly reduced raphe system is present. The raphe branch at the base pole is slightly longer than that at the head pole (Figs $30 \mathrm{~b}, \mathrm{c}$ ). The proximal raphe fissure on the raphe branch at the head pole is slightly expanded into a small proximal pore and slightly bent (Fig. $30 \mathrm{~b}$ ). The raphe branch does not extend onto the valve mantle and terminates just beyond the valve apex (Fig. 30b). Internally, the proximal raphe fissure on the raphe branch at the head pole is slightly expanded and strongly bent (Fig. 30g). Externally, the raphe branch at the base pole is expanded into a drop-shaped proximal pore (Fig. $30 \mathrm{c})$. Internally the proximal raphe fissure is crook-shaped (Fig. 30e).

The striae are parallel throughout the valve length (Fig. 30a). The interstriae (transapical costae) are strongly developed (Figs 30d-f) and are slightly wider than the striae. The foramina are round to elliptical near the axial area, becoming oblong near the head pole and the valve mantle (Figs 30d, g). In a strongly corroded specimen (as in Figs 30e, f) the foramina are oblong. The areolae size increases towards the valve mantle, where they become elongated (Fig. 30b).

Taxonomic note: This combination is often attributed to RABENHORST (1864); however Rabenhorst attributed this species to Gomphonema subdivision Rhoicosphenia. The first author who published the combination Rhoicosphenia fracta is DE TONI (1891) although he placed this taxon among the "species inquirendae". Since the expression of a taxonomic doubt about the species by means of a "?" does not invalidate the combination, his combination is valid (MCNeILL et al. 2006, art. 34.1).

Main differential characters of $R$. fracta are valve shape (narrowly lanceolate to subclavate), small valve width (4-5.5 $\mu \mathrm{m}$ wide) and especially the round areolae. Rhoicosphenia abbreviata has a similar valve outline, but also has a distinct central area on the $\mathrm{R}$-valve, an axial area that gradually widens towards the central area and a broadly rounded head pole (compare Figs $1 \mathrm{~b}-\mathrm{g}$ with Figs $30 \mathrm{~d}-\mathrm{k}$ ). Additionally, differences in areolae shape on the valve face may be observed (compare Figs 2c, 3a with Figs 29c, 30b): while in R. abbreviata the external foramina are narrow, elongated slits, in $R$. fracta the foramina are small and elliptical. $R$. fracta can be differentiated from $R$. tenuis by the lower stria density on the D-valve (13-17/10 $\mu \mathrm{m}$ in $R$. tenuis). The valves of $R$. fracta are comparable with $R$. baicalensis, but both species can be differentiated with SEM by the shape of the areolae on the valve face of the D-valve. In $R$. baicalensis the external foramina are round with equal size throughout, whereas in $R$. fracta the foramina are elliptical to oblong, increasing in size towards the valve mantle. Additionally, the internal proximal raphe fissure in $R$. baicalensis is 
straight, while in R. fracta it is clearly bent. The larger pseudoseptum of $R$. baicalensis is also a distinguishing character.

Ecology: Not precisely known, because so far it is recorded only from the type locality (Königsberg). However, Cleve (1895, p. 166) has listed the Caspian Sea in the distributional record, but this data must be checked. In the freshwater type locality, $R$. fracta was observed in a diatom community dominated by different Fragilaria LyngBye sensu lato $[F$. capucina Desmazières, Staurosira construens Ehrenberg, Staurosirella pinnata (EhrenBerg) D.M. Williams \& Round], Epithemia KützING $[E$. adnata (KüTZING) Brébisson, E. turgida (Ehrenberg) KütZIng, E. sorex KütZing], Amphora Ehrenberg ex KütZIng [A. ovalis (KÜtZInG) KütZIng, A. copulata (Kützing) Schoeman \& Archibald, $A$. indistincta Levkov], Stephanodiscus Ehrenberg and Nitzschia HASSALL species.

\section{Rhoicosphenia adriatica CAPUT MIHALIĆ et Levkov sp. nov. (Figs 31a-aj, 32a-h)}

Diagnosis: Frustula dorsiventralia et heteropolaria. Valvae heteropolares, lanceolatae ad anguste clavatae verticibus distincte obtusius rotundatis quam basipoli. Longitudo 13-45 $\mu \mathrm{m}$, latitudo 3.5-6 $\mu \mathrm{m}$. Ad apices pseudoseptum distinctum adest. Valva concava raphe filiforme et poris centralibus distinctis, area axiali angusta gradatim dilatata, area centrali variabili, parva vel lanceolata, striis transapicalibus parallelis vel minus radiantibus ad apices 15-18 in $10 \mu \mathrm{m}$. Valva convexa raphe reducta curtis fissuris positis ad apices, striis transapicalibus parallelis in media parte vel minus radiantibus ad apices, 1520 in $10 \mu \mathrm{m}$. Puncta striarum facile discernanda. Area porellorum poli basalis distincta.

Description (Figs 31a-aj): In girdle view frustules wedge-shaped and weakly bent (Figs 31a, b). Valves heteropolar, lanceolate to narrowly clavate, head pole more broadly rounded than base pole. Valves 13-45 $\mu \mathrm{m}$ long and 3.5-6 $\mu \mathrm{m}$ wide. Distinct pseudoseptum present at poles. Raphe system differently developed on both valves. Concave valve with well developed filiform raphe and large central pores (Figs 31c-v), convex valve with reduced raphe system of short slits lying close to poles (Figs 31w-aj). Axial area on concave R-valve narrow, lanceolate, slightly widened near central area. Axial area on D-valve variable, moderately wide to very narrow. Striae on $\mathrm{R}$-valve parallel in middle but slightly radiate at apices, $15-18$ in $10 \mu \mathrm{m}$, indistinctly punctate. Striae on convex D-valve, parallel to slightly radiate at apices, $15-20$ in $10 \mu \mathrm{m}$. Pore field present at base poles of both valves.

SEM observations (Figs 32a-h): The concave $\mathrm{R}$-valve is heteropolar with a rounded head pole, and a narrowly rounded base pole (Figs 32a, b, d). The axial area is narrow, tapering towards the central area (Fig. 32c). The raphe system is central. The two raphe slits on the $\mathrm{R}-\mathrm{valve}$ have different lengths, and the raphe branch at the base pole is slightly longer. Externally, the central raphe fissures are expanded and drop-shaped (Figs 32a, b). Internally, the central raphe fissures are crook towards the same side of the valve (Fig. 32d). The terminal raphe fissures are curved and continue onto the valve mantle. The fissure at the base pole is slightly curved (Fig. 32a). The striae are slightly radiate throughout the valve. Each stria comprises a row of elongated areolae (Fig. 32b), while in corroded specimens (as in Fig. 32a) the areolae have round to elliptical openings. Internally they have wider oblong openings, and occasionally the striae are biseriate (Fig. 32d). However, this is not a consistent character. Internally, the interstriae are strongly developed giving a chambered appearance to the areolae (Fig. 32d). Close to the base pole, a pore field with densely packed areolae is present (Figs 32a, f).

The raphe system on the convex D-valve is reduced (Figs 32c, e). The axial area is narrow, and linear. The raphe branch on the head pole is a short slit distally that is slightly dorsal bent at the distal end (Fig. 32g). The proximal raphe fissure is weakly expanded into a pore (Fig. 32g), while internally it is slightly curved (Fig. 32h). The raphe branch on the base pole has an expanded drop-shaped, proximal fissure (Figs 32c, f), while internally the proximal raphe fissures are crookshaped (Fig. 32e). Distally, the raphe continues onto the valve mantle and divides the apical pore field (Fig. 32f). The striae are uniseriate composed of round areolae (Figs 32c, f, g). Striae in the middle of the valve are equally spaced (Fig. 32c). Internally, the interstriae are strongly developed and are narrower than the striae (Fig. 32e).

Holotype: Designated here slide Om14/1 in MKDNC, specimen representing the holotype is Fig. 31 af.

Isotype: Slide ZU7/15 in BRM.

Type locality: Ombla River estuary, Croatia, 200 
$\mathrm{m}$ from the marina Komolac.

Type material: Periphyton, $0.5 \mathrm{~m}$ depth, collection date: 24.7.2006. Accession No. OM14 in MKDNC. Collector: K. Caput Mihalić.

Main differential characters of $R$. adriatica are small valve size, and high stria density. It can be confused with $R$. lacustris (Figs 22a-x), but the latter has consistently broader valves $(6-9 \mu \mathrm{m})$ for any given length with lower stria density (11-15 in $10 \mu \mathrm{m}) . R$. linearis has a comparable stria density $(\mathrm{S}=15-17$ in $10 \mu \mathrm{m})$, but the valves are longer and consistently wider than those of $R$. adriatica, and the striae are distinctly punctate. $R$. baltica (Figs $4 a-v$ ) has a different valve shape (base pole distinctly protracted to subcapitate) and thus may be easil y distinguish from $R$. adriatica.

Ecology: Rhoicosphenia adriatica is a brackish water species frequently observed in periphyton samples from the estuary of River Ombla (Eastern Adriatic coast). River Ombla is the smallest karstic river in the Adriatic catchment area (30 km long), forming a stratified estuary (4 $\mathrm{km}$ long, 200-300 m wide). Salinity in the estuary varied between 17.95 and $37.87 \%$ and temperature between 17.5 and $23.7{ }^{\circ} \mathrm{C}$ in July 2006. There was no observable pattern of vertical or temporal changes in orthophosphate concentrations $(0.10$ $\left.0.24 \mu \mathrm{mol} . \mathrm{l}^{-1}\right)$. The highest concentrations of total inorganic nitrogen $\left(4.43 \mu \mathrm{mol} .1^{-1}\right)$ and silicates $\left(9.34 \mu \mathrm{mol} . \mathrm{l}^{-1}\right)$ were detected at $1.5 \mathrm{~m}$ depth. Water transparency was $3.5 \mathrm{~m}$ and oxygen saturation ranged from 77 to $111 \%$.

\section{Rhoicosphenia omblaensis CAPUT MiHALIĆ et Levkov sp. nov. (Figs 33a-t)}

Synonyms: Rhoicosphenia marina (W. SмITH) M. Schmidt sensu Cardinal et al. 1984, fig. 82; ?Rhoicosphenia marina (W. SмIтH) M. SснмIDT pro parte Schmidt 1899 in Schmidt et al. 1874-1959, fig. 213: 32-33.

Diagnosis: Frustula dorsiventralia et heteropolaria. Valvae heteropolares, anguste lineares anguste clavatae verticibus distincte obtusius rotundatis quam basipoli. Longitudo 18.5-35.5 $\mu \mathrm{m}$, latitudo 4.5-6 $\mu \mathrm{m}$. Ad apices pseudoseptum distinctum adest. Valva concava raphe filiformi et poris centralibus distinctis, area axiali angustissima, area centrali constricta in media parte, apparenter sicut duabus hyalinas areas prope poros centrales, striis transapicalibus parallelis vel minus radiantibus ad apices 19-23 in
$10 \mu \mathrm{m}$. Valva convexa raphe reducta curtis fissuris positis ad apices, striis transapicalibus parallelis in media parte vel minus radiantibus ad apices, 20-24 in $10 \mu \mathrm{m}$. Puncta striarum discernanda. Area porellorum poli basalis non distincta.

Description: Frustules in girdle view wedgeshaped (Figs 33a, b). Valves heteropolar, narrowly linear, with obtuse to round head pole and narrowly rounded base pole. Valve length varies between 18.5 and $35.5 \mu \mathrm{m}$, and valve width between 4.5 and $6 \mu \mathrm{m}$. Raphe system differently developed on two valves. Concave valve, a well-developed filiform raphe with large central pores (Figs $33 \mathrm{c}-\mathrm{m})$. Convex valve, raphe system reduced to short slits close to poles (Figs 33n-s). Axial area on concave $\mathrm{R}$-valve narrow, the central area with mid-constriction, expressed as two narrow hyaline areas around central pores. Striae on $\mathrm{R}$-valve parallel in middle, becoming slightly radiate towards ends, $19-23$ in $10 \mu \mathrm{m}$, distinctly punctate. Striae on D-valve parallel throughout, finely punctate, $20-24$ in $10 \mu \mathrm{m}$. Pore fields not present at base pole of either valve.

SEM external view of the D-valve (Fig. 33t) shows that the striae are composed of small, round areolae. The raphe branch at the head pole is long, as opposed to other species where it is very short. Near the valve edge in the region of the helictoglossa, a small hyaline area is present. The distal raphe ending at the base pole is simply curved and does not extend onto the valve mantle. A typical pore field cannot be observed, although the areolae near the base pole are smaller and more densely spaced. However, they are arranged in transapical rows, as are the striae (not in an oblique arrangement as in other Rhoicosphenia species).

Holotype: Designated here slide $\mathrm{Om} 7 / 2$ in MKDNC, specimen representing the holotype is Fig. 33i.

Isotype: Slide ZU7/16 in BRM.

Type locality: River Ombla estuary, Croatia, 200 $\mathrm{m}$ from the marina Komolac.

Type material: Periphyton, $0.2 \mathrm{~m}$ depth, collection date: 17.07.2006. Accession No. OM7 in MKDNC. Collector: K. Caput Mihalić

Main differential characters of $R$. omblaensis are the distantly spaced proximal raphe endings on the $\mathrm{R}$-valve, the shape of the central area and the densely spaced striae. This combination of characters enables easy differentiation from 
other Rhoicosphenia species. With SEM, it can be differentiated by the length of the raphe branch at the head pole and absence of an apical pore field at the base pole.

Ecology: Brackish water species, present in several samples from Ombla River, but always rare. For ecology of Ombla estuary see above. CARdinal et al. (1984, fig. 82) have recorded this species as a very rare taxon from the Baie des Chaleurs, Canada. Another specimen identified from the Mediterranean Sea as $R$. marina by WitKOwsKi et al. (2000, fig. 58: 20), is probably conspecific with $R$. omblaensis, having a similar valve outline and central area shape. Other records of this species cannot be verified from the available references.

\section{Rhoicosphenia sp. 1 (Figs 33u-aa)}

LM observations (Figs 33u-aa): In girdle view, frustules have a bent wedge shape (Fig. 33u). Valves are heteropolar, broadly clavate, with a narrowly rounded head pole and an attenuate base pole. Valve length of observed valves varies from 16 to $24 \mu \mathrm{m}$, and valve width from 6.7 to $8 \mu \mathrm{m}$. Length-to-width ratio around 2. The concave $\mathrm{R}$-valve has a fully developed raphe with large central pores (Figs $33 \mathrm{v}-\mathrm{x}$ ), while the convex D-valve has a reduced raphe system, with short slits lying close to the poles (Figs 33y-aa). The

Key for identification of Rhoicosphenia species observed in this study

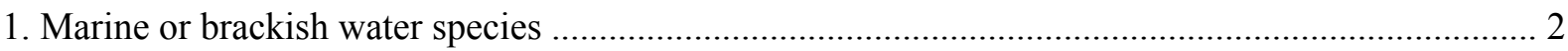

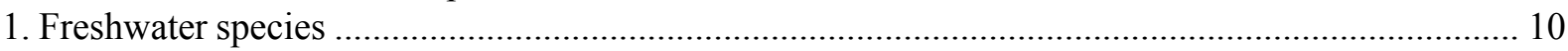

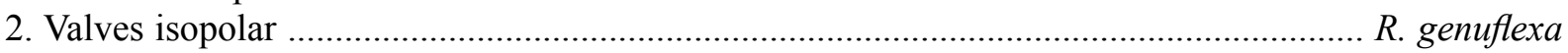

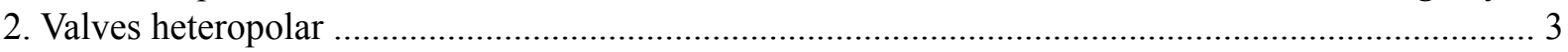

3. Central area of the $\mathrm{R}-\mathrm{valve}$ constricted in the middle, striae 19-23 in $10 \mu \mathrm{m}$, distinctly punctate .......

R. omblaensis

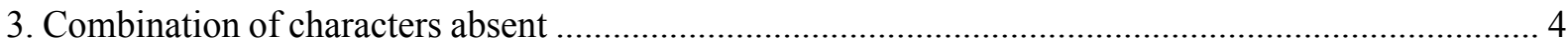

4. Raphe absent on the head pole of the convex D-valve, areolae coarse ................................ R. flexa

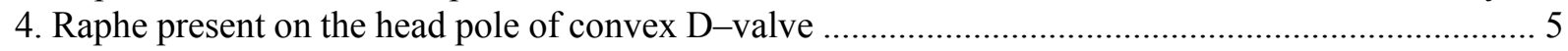

5. Valves broadly clavate with an obtusely rounded head pole and width greater than $8.5 \mu \mathrm{m}$.

. marina

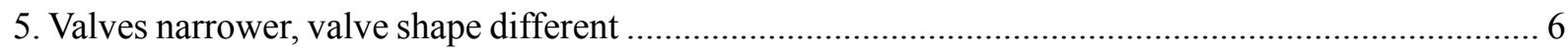

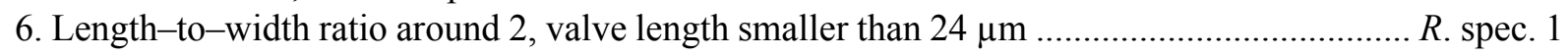

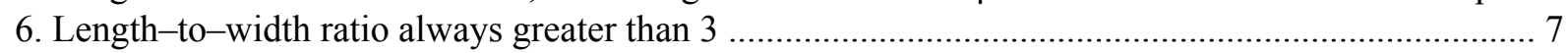

7. Base pole distinctly protracted and subcapitate ............................................................ R. baltica

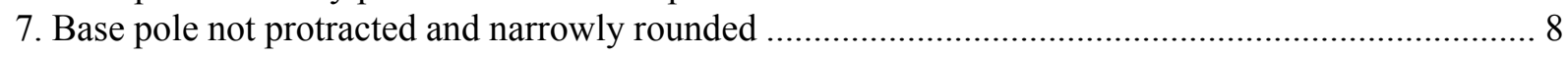

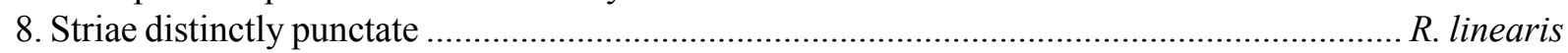

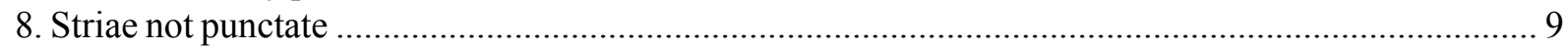

9. D-valve with 11-15 striae in $10 \mu \mathrm{m}$, valve width greater than $6 \mu \mathrm{m}$, smaller specimens with a cuneate head pole

R. lacustris

9. D-valve with 15-20 striae in $10 \mu \mathrm{m}$, valve width smaller than $6 \mu \mathrm{m}$, head pole broadly rounded ........

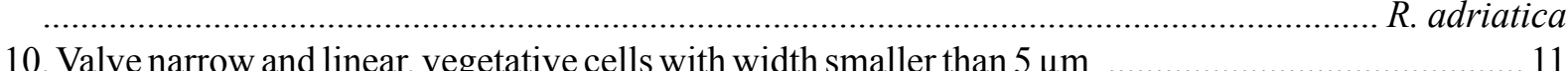

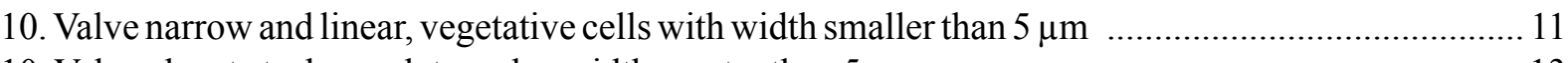

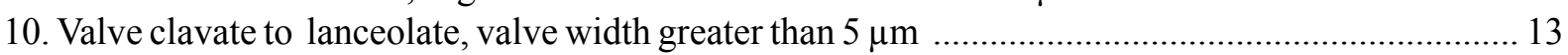

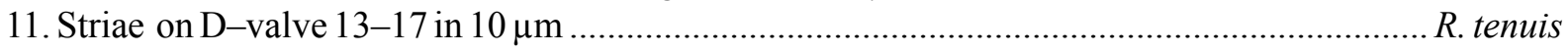

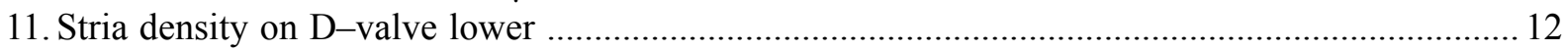

12. Areolae round, equal in size throughout ............................................................... R. baicalensis

12. Areolae elliptical to oblong, increasing in size towards the valve mantle ........................ R. fracta

13. D-valve with densely spaced striae 22-24 in $10 \mu \mathrm{m}$............................................... R. macedonica

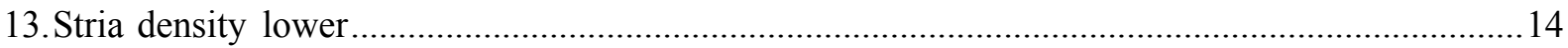

14. D-valve with 9-12 striae in $10 \mu \mathrm{m}$, striae widely spaced in valve middle ................. R. abbreviata

14. Stria density higher than 11 striae in $10 \mu \mathrm{m}$, striae equally spaced in the middle of the valve ..............15

15. Valves lanceolate with an attenuated to subprotracted head pole ......................................... R. affinis

15. Valve clavate with an obtusely rounded head pole ....................................................... R. lacustris 
axial area on the concave $\mathrm{R}$-valve is very narrow. The central area is weakly expressed. The axial area on the convex D-valve is narrow and linear. Striae on R-valve are densely spaced, 18-20 in $10 \mu \mathrm{m}$, and parallel to weakly radiate throughout the whole valve length. Striae on the D-valve are parallel to slightly radiate, $18-21$ in $10 \mu \mathrm{m}$. Punctation of striae is not visible. A distinct pore field is present at the base pole of both valves.

Main differential characters of Rhoicosphenia sp. 1 are the short but wide valves. The valves of this taxon are consistently wider than the valves of other species. However, its identity remains unclear because the whole diminution series is wanting.

Ecology: This taxon has only been so far observed in the Baltic Sea, where it is rare.

\section{Acknowledgement}

This study was funded by the Alexander von Humboldt Foundation and BASILEUS program. The authors want to express their gratitude to Dr. Richard Crawford and Mrs. Friedel Hinz, Friedrich Hustedt Centre for Diatom Studies, Alfred Wegener Institute for Polar and Marine Research, Bremerhaven, for their support at the early stages of this study and to Dr. Maria Angélica Oliveira, Universidade Federal de Santa Maria (Brazil), for kindly revising the English of this manuscript. The helpful reviews by Paul Hamilton, The Canadian Museum of Nature, and an anonymous reviewer were greatly appreciated.

\section{References}

Agardh, C.A. (1831): Conspectus Criticus Diatomacearum. Part III. - Lundae Literis Berlingianis, Lund.

Al-Handal, A.Y. \& WulfF, A. (2008): Marine benthic diatoms from Potter Cove, King George Island, Antarctica. - Bot. Mar. 51: 51-68.

Argumedo Hernández, U. \& Siqueiros Beltrones, D.A. (2008): Cambios en la estructura de la asociación de diatomeas epifitas de Macrocystis pyrifera (L.) C. Ag. - Acta Bot. Mex. 82: 4366.

BERG, Å. (1952): Eine Diatomeengemeinschaft an der schwedischen Ostküste. - Ark. Bot. 2: 1-39.

Berg, Å. \& Hessland, I. (1949): A quaternary diatom spectrum from Bohuslän. - Ark. Mineral. Geol. 1: 169-198.

Cardinal, A., Poulin, M. \& Bérard-Therriault, L. (1984): Les diatomées benthiques de substrats durs des eaux marines et saumâtres du Québec.
4. Naviculales, Naviculaceae (à l'exclusion des genres Navicula, Donkinia, Gyrosigma et Pleurosigma). - Naturaliste Canad. 111: 369394.

Carrada, G.C., Fresi, E., Marino, D., Modigh, M. \& D’AlCALÀ, M.R. (1981): Structural analysis of winter phytoplankton in the Gulf of Naples. - J. Plankt. Res. 3: 291-314.

Cleve, P.T. (1895): Synopsis of the Naviculoid Diatoms, Part II.- Kongl. Svenska Vetensk. Acad. Handl. 27: 1-219.

Cleve-Euler, A. (1915): New contributions to the diatomaceous flora of Finland. - Ark. Bot. 14: $1-81$.

Cleve-Euler, A. (1953): Die Diatomeen von Schweden und Finnland. Teil III. Monoraphideae, Biraphideae 1. - Kongl. Svenska Vetensk. Acad. Handl. Fjärde, Ser. 4. - 255 pp., Stockholm.

Cocquyt, C. (1998): Diatoms from the Northern Basin of Lake Tanganyika. - Biblioth. Diatomol. 39: $1-275$.

De Toni, G.B. (1891): Sylloge algarum omnium hucusque cognitarum, vol. 2. Bacillariaceae. Sectio 1, Raphidea. - 490 pp., Patavii, Typis Deminarii.

Fourtanier, E. \& Kociolek, J.P. (2008): Catalogue of diatom names, California Academy of Sciences, On-line Version [www.calacademy. org/research/diatoms /names/index.asp].

Geitler, L. (1932): Der Formwechsel der pennaten Diatomeen (Kieselalgen). - Arch. Protistenk. 78: $1-226$.

Geitler, L. (1952): Die auxosporenbildung von Rhoicosphenia curvata. - Österr. Bot. Z. 99: 78-88.

GiffEN, M.H. (1970): New and interesting marine and littoral diatoms from Sea Point, near Cape Town, South Africa. - Bot. Mar. 13: 87-99.

Giffen, M.H. (1973): Diatoms of the marine littoral of Steenberg's Cove in St. Helena Bay, Cape Province, South Africa. - Bot. Mar. 16: 32-48.

Grunow, A. (1860): Ueber neue oder ungenügend gekannte Algen. Erste Folge, Diatomeen, Familie Naviculaceen. - Verh. K. K. Zool.-Bot. Ges. Wien 10: 503-582.

GüTtINGER, W. (1991): Collection of SEM micrographs of diatoms Series 5. - 50 pl., W. Güttinger, Pura.

Hoagland, K.D., Roemer, S.C. \& Rosowski, J.R. (1982): Colonization and community structure of two periphyton assemblages, with emphasis on the diatoms (Bacillariophyceae). - Amer. J. Bot. 69: 188-213.

Hustedt, F. (1930): Bacillariophyta (Diatomeae). In: PAscher, A. (ed.): Die Süßwasserflora von Mitteleuropas, Heft 10. - 466 pp., Gustav Fisher Verlag, Jena.

Hustedt, F. (1933): Die Kieselalgen Deutschlands, 
Österreichs und der Schweiz. - In: RABENHORST, L. (ed.): Kryptogamenflora von Deutschland, Österreich und der Schweiz. Band 7, Teil 2, Lief. 3. - pp. 321-432, Akademische Verlagsgesellschaft, Leipzig.

Hustedt, F. (1959): Die Kieselalgen Deutschlands, Österreichs und der Schweiz. - In: RABENHORST, L. (ed.): Kryptogamen-Flora von Deutschland, Österreich und der Schweiz. Band VII, Teil 2. - 845 pp., Akademische Verlagsgesellschaft, Leipzig.

Kawashima, A. \& Kobayasi, H. (1996): Diatoms from Akan-ko (Lake Akan) in Hokkaido, Japan. 4: Raphid diatoms: Eunotia, Cocconeis, Achnanthes, Rhoicosphenia. - Nat. Environm. Sci. Res. 9: 15-32.

Kelly, M. \& Whitton, B.A. (1995): The trophic diatom index: A new index for monitoring eutrophication in rivers. - J. Appl. Phycol. 7: 433-444.

Krammer, K. \& Lange-Bertalot, H. (1986): Bacillariophyceae 1. Teil: Naviculaceae. - In: Ettl, H., Gerloff, J., Heynig, H. \& Mollenhauer, D. (eds): Süsswasserflora von Mitteleuropa 2/1. - 876 pp., Gustav Fischer Verlag, Stuttgart \& New York.

Krammer, K. \& Lange-Bertalot, H. (1991): Bacillariophyceae. 4: Achnanthaceae. - In: Ettl, H., Gärtner, G., Gerloff, J., Heynig, H. \& Mollenhauer, D. (eds): Süßwasserflora von Mitteleuropa. 2/4. - 437 pp., Gustav Fischer Verlag, Stuttgart.

KütZING, F.T. (1833): Synopsis Diatomacearum oder Versuch einer systematischen Zusammenstellung der Diatomeen. - Linnaea 8: 529-620.

KützING, F.T. (1844): Die Kieselschaligen. Bacillarien oder Diatomeen. - 152 pp., 30 pls, W. Köhne, Nordhausen.

Lange-Bertalot, H. (1980): Ein Beitrag zur Revision der Gattungen Rhoicosphenia Grun., Gomphonema C. Ag., Gomphoneis Cl. - Bot. Not. 133: 585-594.

Levkov, Z. \& Nakov, T. (2008): Rhoicosphenia tenuis, a new diatom species from Lake Ohrid. Diatom Res. 23: 377-388.

Levkov, Z. \& Stojanovski, P. (2001): Changes in diatom flora in Doiran Lake in past 13 years. Annual Biol. 53: 22-38.

Levkov, Z., Krstic, S., Metzeltin, D. \& Nakov, T. (2007): Diatoms of Lakes Prespa and Ohrid. About 500 taxa from ancient lake system. In: LANGE-Bertalot, H. (ed.): Iconographia Diatomologica. Annotated diatom micrographs, Vol. 16, Biogeography-Ecology-Taxonomy. - 611 pp., A.R.G. Gantner, Ruggell, Liechtenstein.

ManN, D.G. (1982a): Structure, life history and systematics of Rhoicosphenia (Bacillariophyta).
I. The vegetative cell of Rh. curvata. - J. Phycol. 18: $162-176$.

ManN, D.G. (1982b): Structure, life history and systematics of Rhoicosphenia (Bacillariophyta). II. Auxospore formation and perizonium structure of Rh. curvata. - J. Phycol. 18: 264274.

ManN, D.G. (1984): Structure, life history and systematics of Rhoicosphenia (Bacillariophyta). $\mathrm{V}$. Initial cell and size reduction in $R h$. curvata and a description of the Rhoicospheniaceae fam. nov. - J. Phycol. 20: 544-555.

McNeill, J., Barrie, F.R., Burdet, H.M. et al. (2006): International Code of Botanical Nomenclature. - Regnum Vegetabile 146: 1-568. A.R.G. Gantner Verlag KG.

Medlin, L.K. \& FryXell, G.A. (1984a): Structure, life history and systematics of Rhoicosphenia (Bacillariophyta). III. Rh. adolfii and its relationship to Rhoiconeis. - In: MANN, D.G. (ed.): Proceeding of the $7^{\text {th }}$ International Diatom Symposium. - pp. 255-263, Koeltz, Koenigstein.

Medin, L.K. \& Fryxell, G.A. (1984b): Structure, life history and systematics of Rhoicosphenia (Bacillariophyta). IV. Correlation of size reduction with changes in valve morphology of Rh. genuflexa. - J. Phycol. 20: 101-108.

MereschKowsky, C. (1902): Note sur les diatomées de Guenitschesk (Mer d'Azow). - Odesskoe obshchestvo estestvoispytatelei (Odessa) 24: 34-72.

Мiно, A. \& Witкowski, A. (2005): Diatom (Bacillariophyta) flora of Albanian coastal wetlands taxonomy and ecology: A review. Proc. Calif. Acad. Sci. 56: 129-145.

Morales, E.A. \& Vis, M.L. (2007): Epilithic diatoms (Bacillariophyceae) from cloud forest and alpine streams in Bolivia, South America. - Proc. Acad. Nat. Sci. Philadelphia 156: 123-155.

NAgumo, T. \& TANAKA, J. (1994): Epiphytic diatoms on a red alga, Ptilota filicina J. Ag., in Hokkaido, Japan. - Mem. Natl. Sci. Mus. (Tokyo) 27: 43-53.

Oкuno, Н. (1974): Freshwater diatoms. In: Helmcke, J.-G., Krieger, W. \& Gerloff, J. (eds): Diatomeenschalen im elektronenmikroskopischen Bild. Vol. IX. - pls 825-923, J. Cramer, Vaduz.

Østrup, E. (1904): Marine diatoms. Flora of Koh Chang. Contributions to the knowledge of the vegetation in the Gulf of Siam. Part VIII. - Bot. Tidsskr. 26: 115-161.

Østrup, E. (1910): Danske Diatoméer. -323 pp., 5 pls. Reitzel Verlag, Kopenhagen.

PAnKow, H. (1976): Algenflora der Ostsee. II. Plankton. - 493 pp., Gustav Fischer Verlag, Stuttgart.

Patrick, R.M. \& Reimer, C.W. (1966): The diatoms 
of the United States, exclusive of Alaska and Hawaii. Vol. 1: Fragilariaceae, Eunotiaceae, Achnanthaceae, Naviculaceae. - Monogr. Acad. Nat. Sci. Philadelphia 13: 1-688.

Peragallo, H. \& Peragallo, M. (1897-1908): Diatomées marines de France et des districts maritimes voisins. - 491 pp., Tempère, Grezsur-Loing.

RABENHORST, L. (1864): Flora Europaea Algarum aquae dulcis et submarinae. Sectio I. Algas diatomaceas complectens, cum figuris generum omnium xylographice impressis. - 359 pp., Apud Eduardum Kummerum, Lipsiae.

Rivera, P. \& Barrales, H. (1989): El género Rhoicosphenia Grunow (Bacillariophyceae) en Chile. - Gayana, Bot. 46: 213-223.

Round, F.E. (1996): Fine detail of siliceous components of diatom cells. - Nova Hedwigia Beih. 112: 201-213.

Round, F.E., Crawford, R.M. \& Mann, D.G. (1990): The diatoms. Biology and morphology of the genera. -747 pp., Cambridge University Press, Cambridge.

Rumrich, U., Lange-Bertalot, H. \& Rumrich, M. (2000): Diatomeen der Anden von Venezuela bis Patagonien/Feuerland.-In:LANGE-Bertalot, $\mathrm{H}$. (ed.): Iconographia Diatomologica. Annotated diatom micrographs. Vol. 9. PhytogeographyDiversity-Taxonomy. - 649 pp., Koeltz Scientific Books, Königstein, Germany.

Salah, M.M. (1955): Some new diatoms from Blakeney Point (Norfolk). - Hydrobiologia 7: 88-102.

Schmidt, A., et al. (1874-1959): Atlas der Diatomaceen - Kunde, Tafeln 1-460. - Aschersleben and Leipzig.

Schumann, J. (1862): Preussische Diatomeen. Schriften Königl. Phys.-Ökon. Ges. Königsberg 3: 166-192, pls 8, 9.

Schumann, J. (1867): Preussische Diatomeen. Schriften Königl. Phys.-Ökon. Ges. Königsberg 8: 37-68, pls 1-3.

SkABITCHEWSKi, A.P. (1976): New species of Diatomeae from overgrowths of the Baikal sublittoral. Ukrayins'k. Bot. Zhurn. 33: 268-271.

Skvortzow, B.W. \& Meyer, C.I. (1928): A contribution to the diatoms of Baikal lake. - Trudy Sungar. Rechn. Biol. Stantsii 1: 1-52.

Smith, W. (1853): Synopsis of British Diatomaceae. 89 pp., pls 1-31, John Van Voorst, London.

Snoeiss, P. (1993): Intercalibration and distribution of diatom species in the Baltic Sea, Vol. 1. - 129 pp., Opulus Press, Uppsala.

Steinman, A.D. \& McIntire, C.D. (1987): Effects of irradiance on the community structure and biomass of algal assemblages in laboratory streams. - Canad. J. Fish. Aquatic Sci. 44: 1640-1648.

Strickland, J.D.H. \& Parsons, T.R. (1972). A Practical
Handbook of Seawater Analysis, $2^{\text {nd }}$ ed. - Fish. Res. Bd. Canada Bull. 167: 1-311.

Van Dam, H., Mertens, A. \& Sinkeldam, J. (1994): A coded checklist and ecological indicator values of freshwater diatoms from The Netherlands. Netherlands J. Aquatic Ecol. 28: 117-133.

Van Heurck, H. (1880-1885): Synopsis des Diatomées de Belgique, Texte et Atlas. - 235 pp., 135 pls, H. Van Heurck, Anvers.

VanLandingham, S.L. (1978): Catalogue of the Fossil and Recent Genera and Species of Diatoms and their Synonyms. Part 7. Rhoicosphenia through Zygoceros. - pp. 3606-4241, J. Cramer, Vaduz.

WENDKER, S. (1990): Untersuchungen zur subfossilen und rezenten Diatomeenflora des Schlei-Ästaurs (Ostsee). - Biblioth. Diatomol. 21: 1-268.

Witkowski, A., Lange-Bertalot, H. \& Metzeltin, D. (2000): Diatom flora of marine coasts 1. In: LANGe-Bertalot, H. (ed.): Iconographia Diatomologica. Annotated diatom micrographs. Vol. 7. Phytogeography-Diversity-Taxonomy.925 pp., A.R.G. Gantner Verlag K.G., Ruggell.

Wuchter, C., Marquardt, J. \& Krumbein, W.E. (2003): The epizoic diatom community on four bryozoan species from Helgoland (German Bight, North Sea). - Helgoland Mar. Res. 57: 13-19. 


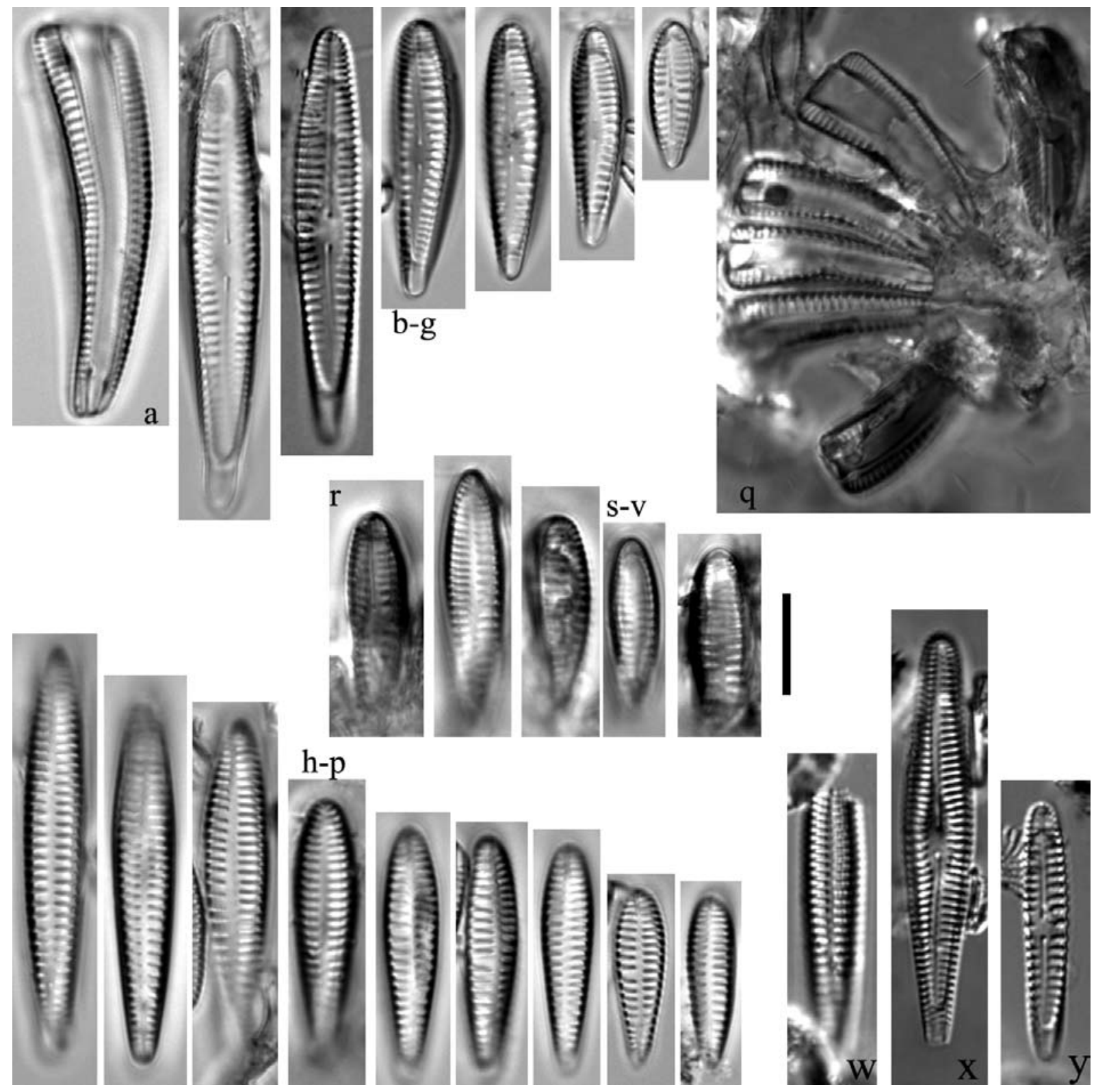

Figs 1a-v. Rhoicosphenia abbreviata, LM: (1a-p) Leipzig Wasserfall in den Promenaden, Germany, (1a) frustule in girdle view, (1b-g) diminution series of the concave R-valve, (1h-p) diminution series of the convex D-valve, (1q-v) Würzburg, Germany, type material. Figs 1w, x. Rhoicosphenia curvata var. major. Fig. 1y. Rhoicosphenia curvata f. minor: (1w-y) Oregon, Pitt River, USA. Scale bar $10 \mu \mathrm{m}$. 

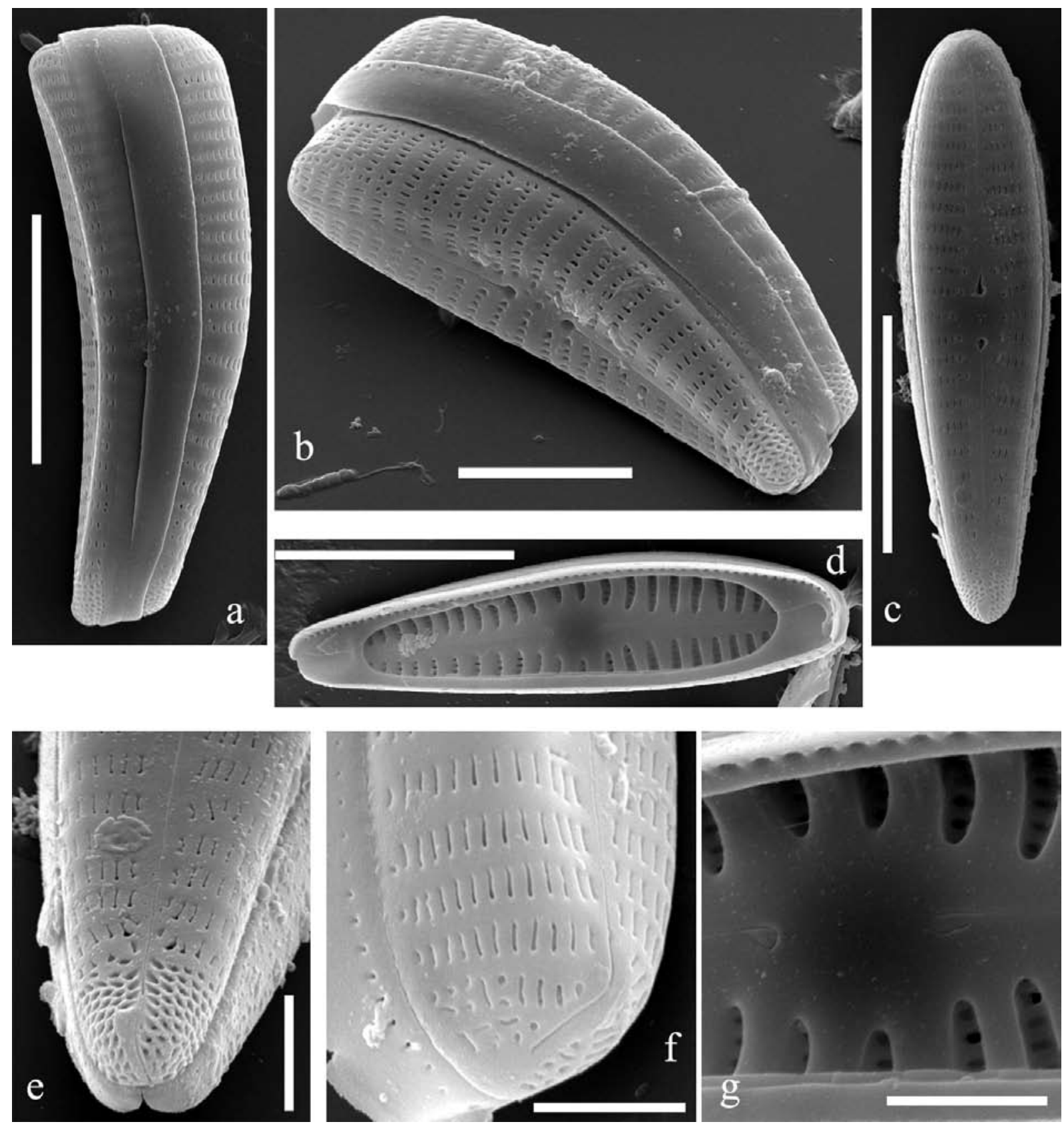

Figs 2a-g. Rhoicosphenia abbreviata, SEM, whole frustule and concave $\mathrm{R}-$ theca: $(2 \mathrm{a}, 2 \mathrm{~b})$ external view of frustule in girdle view, (2c) external view of R-valve, the striae are distantly spaced, (2d) internal view of R-valve. note the modified valvocopula which covers the pseudoseptum, the valvocopula bears a single row of poroids, (2e) detail of the base pole showing the pore field and doubly curved distal raphe fissure, (2f) detail of the head pole, showing the distal raphe fissure extending onto the valve mantle, $(2 \mathrm{~g})$ detail of the internal valve centre showing the crook-shaped central raphe fissures. Scale bar $10 \mu \mathrm{m}$ (Figs 2a, 2c, 2d), $5 \mu \mathrm{m}$ (Fig. 2b), $2 \mu \mathrm{m}$ (Figs 2e-g). 

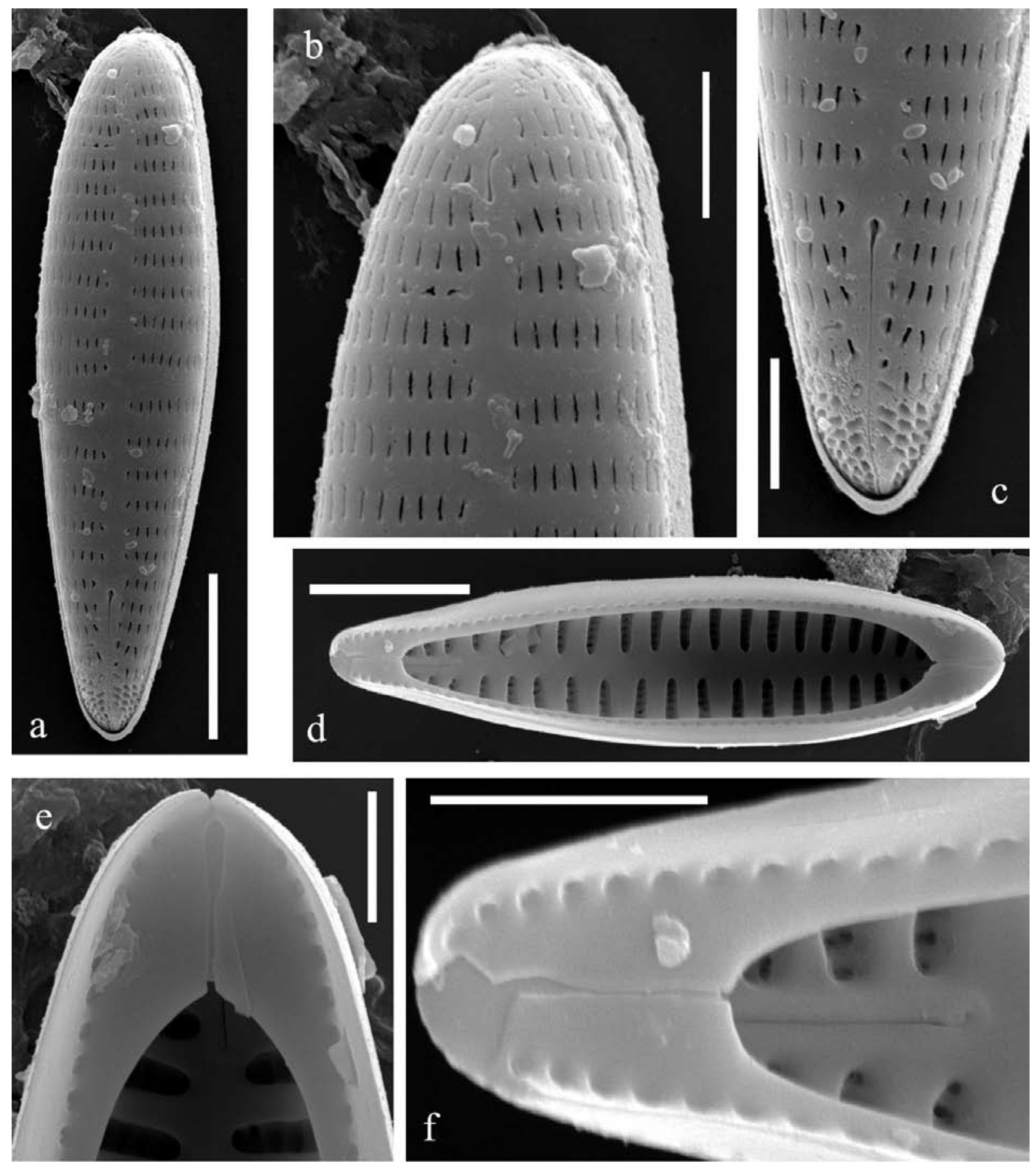

Figs 3a-f. Rhoicosphenia abbreviata, SEM, convex D-valve: (3a) external view of the whole valve, (3b) detail of the head pole showing the reduced raphe branch, (3c) external view of Fig. 3a base showing the raphe branch and the apical pore field, (3d) internal view of whole valve and valvocopula, the valvocopula fits the pseudoseptum which can be seen just underneath, (3e) internal view of Fig. 3d head pole showing the slightly bent proximal raphe fissure, (3f) internal view of Fig. 3d base pole showing the crook-shaped proximal raphe fissure and septa and pseudosepta just underneath. Scale bar $5 \mu \mathrm{m}$ (Figs 3a, 3d), 2 $\mu \mathrm{m}$ (Figs 3b, 3c, 3e, 3f). 

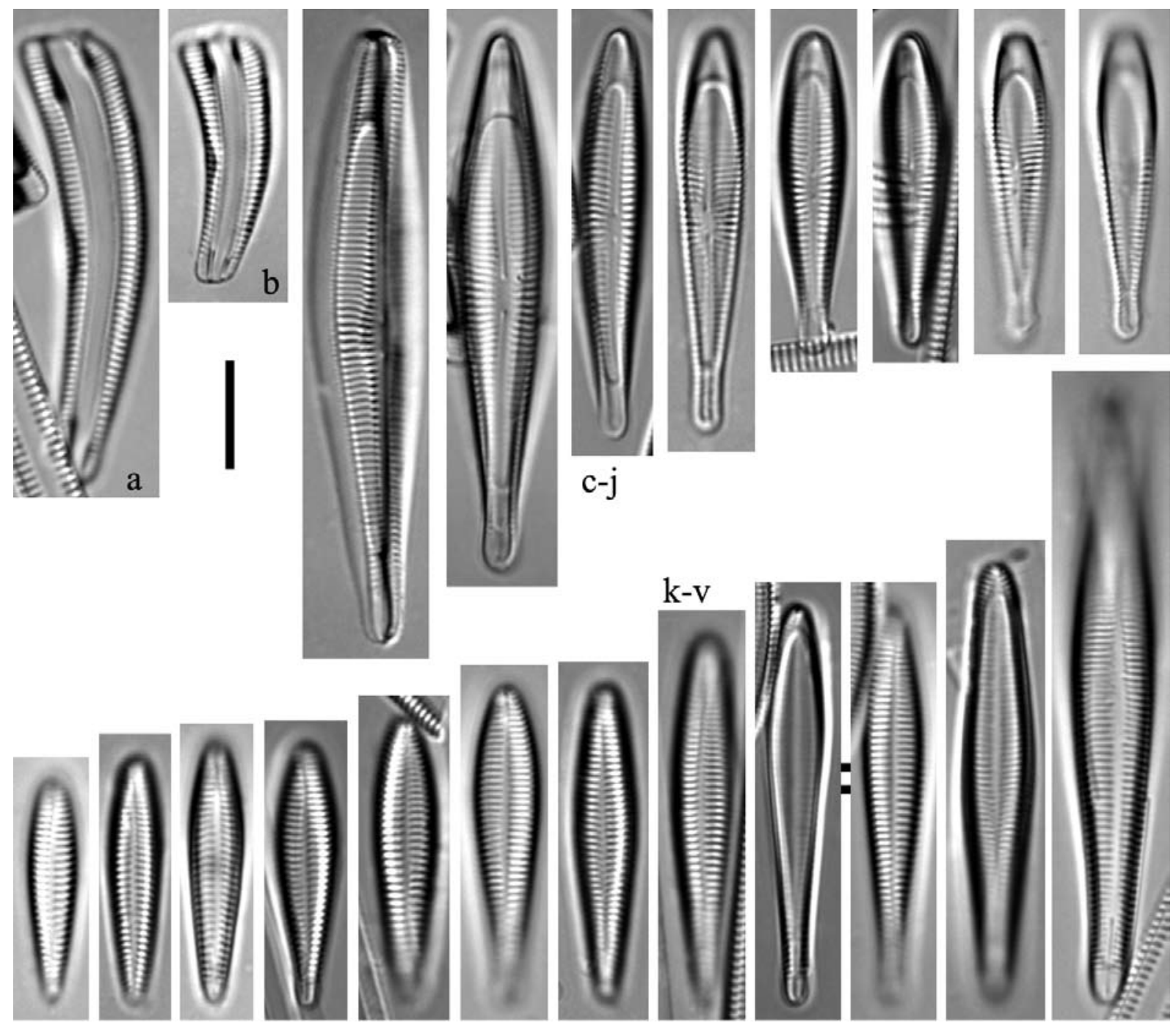

Figs 4a-v. Rhoicosphenia baltica, LM, Baltic Sea, Schleswig-Holstein, macrophytes: (4a, 4b) frustules in girdle view, (4c-j) diminution series of the concave $\mathrm{R}-\mathrm{valve},(4 \mathrm{k}-\mathrm{v})$ diminution series of the convex D-valve. Scale bar $10 \mu \mathrm{m}$. 

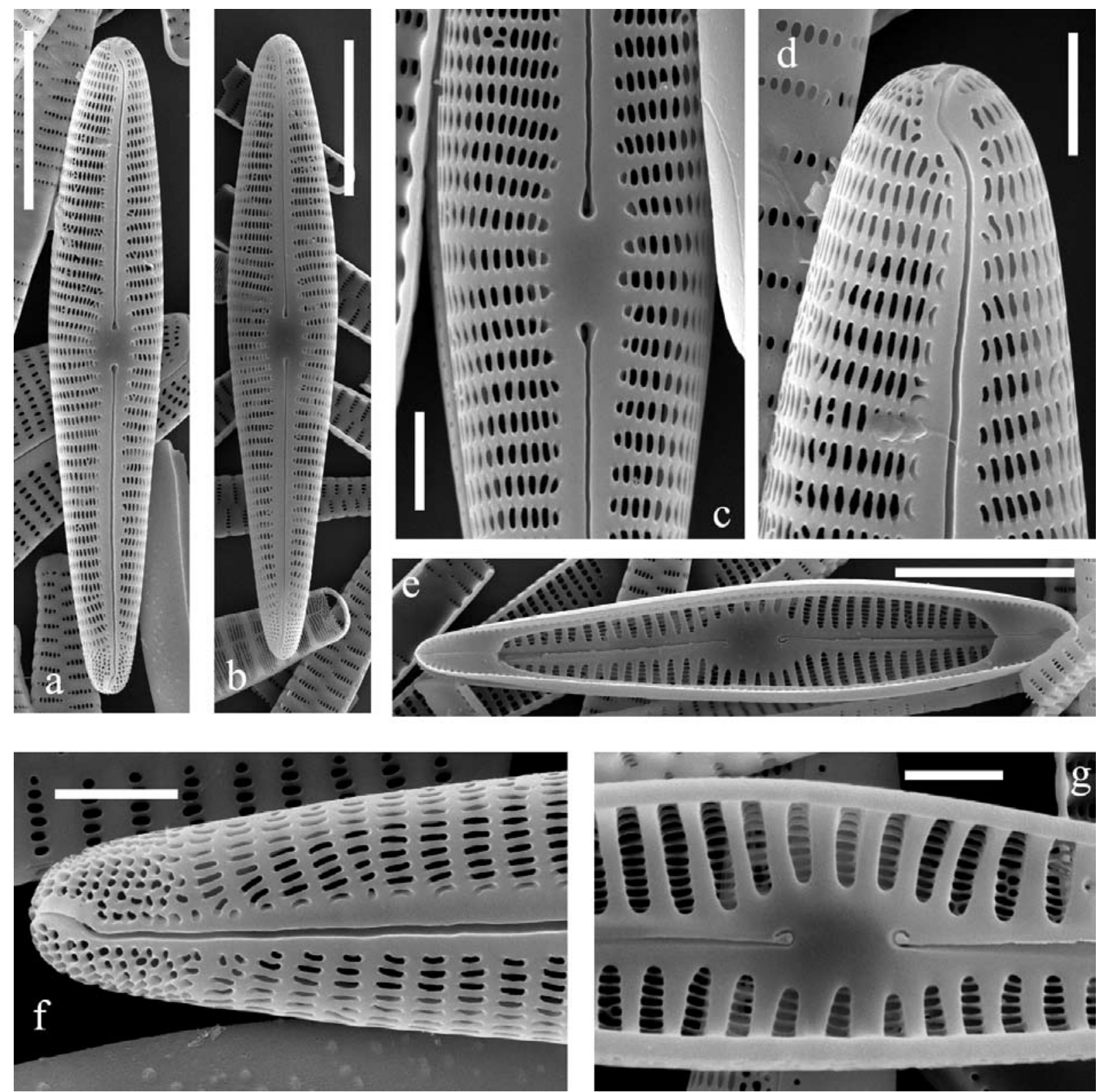

Figs 5a-g. Rhoicosphenia baltica, SEM, concave R-valve: $(5 a, 5 b)$ external view of whole valves, $(5 c)$ detail of the valve centre showing drop-shaped central pores, (5d) detail of the head pole of Fig. 5a showing the doubly curved distal raphe fissure, (5e) internal view of whole valve and valvocopula, (5f) detail of the base pole of Fig. 5a showing the strongly doubly curved distal raphe fissure and the apical pore field, $(5 \mathrm{~g})$ internal view of the valve centre of Fig. 5e showing the crook-shaped central fissures. Scale bar $10 \mu \mathrm{m}$ (Figs 5a, 5b, 5e), $2 \mu \mathrm{m}$ (Figs 5c, 5d, 5f, 5g). 

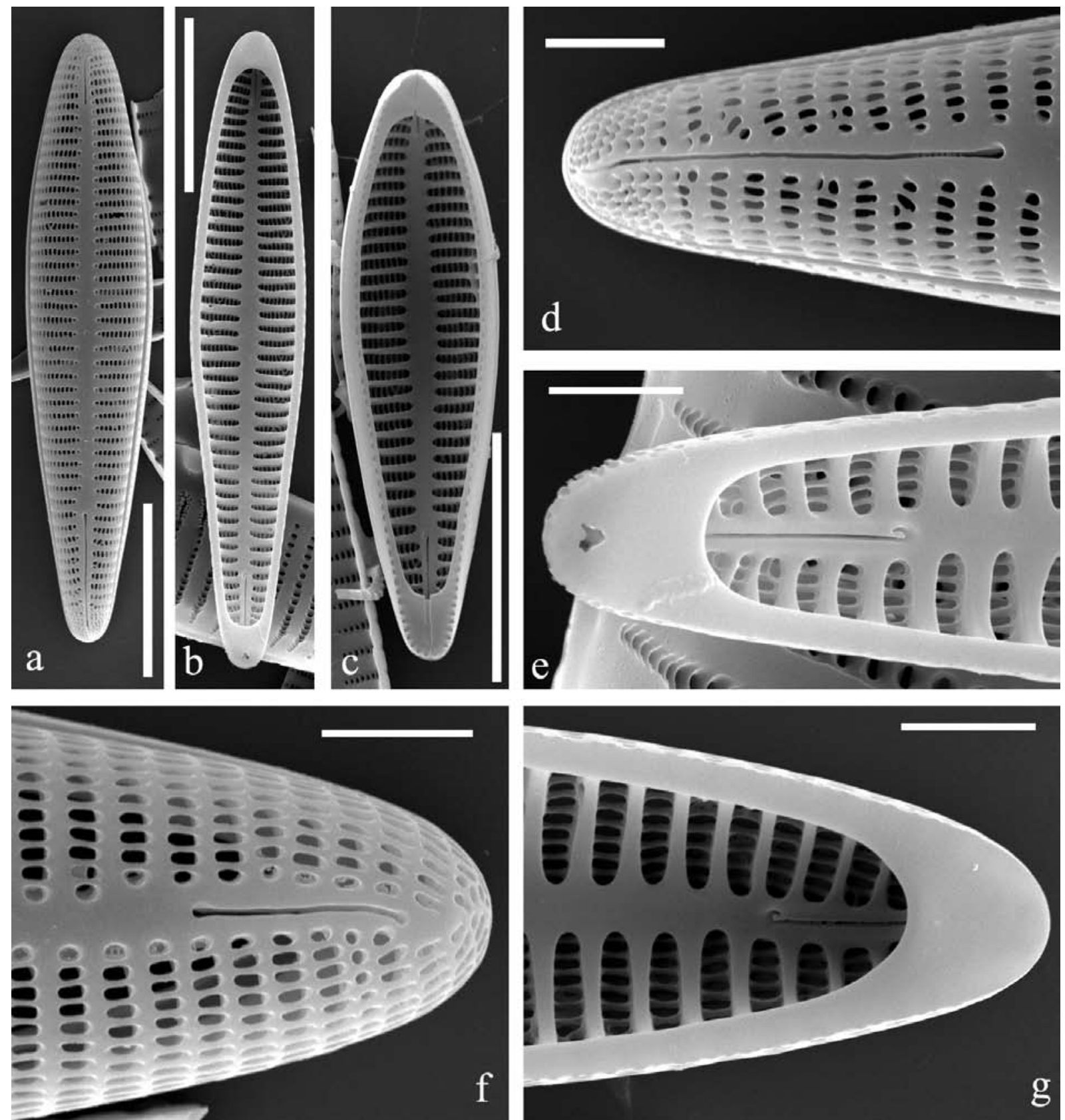

Figs 6a-g. Rhoicosphenia baltica, SEM, convex D-valve: (6a) external view of whole valve, $(6 \mathrm{~b}, 6 \mathrm{c})$ internal view of whole valve, (6d) detail of the base pole of Fig. 6a showing the slightly curved distal raphe fissure and apical pore field, (6e) internal view of the base pole of Fig. $6 \mathrm{~b}$ showing the crook-shaped proximal raphe fissure and pseudosepta, (6f) detail of the head pole of Fig. 6a showing the short raphe branch, proximally the raphe branch terminates with a small proximal pore, $(6 \mathrm{~g})$ internal view of the head pole of Fig. $6 \mathrm{c}$ showing the crook-shaped proximal raphe fissure and pseudosepta. Scale bar $10 \mu \mathrm{m}$ (Figs $6 \mathrm{a}-\mathrm{c}$ ), $2 \mu \mathrm{m}$ (Figs $6 \mathrm{~d}-\mathrm{g})$. 


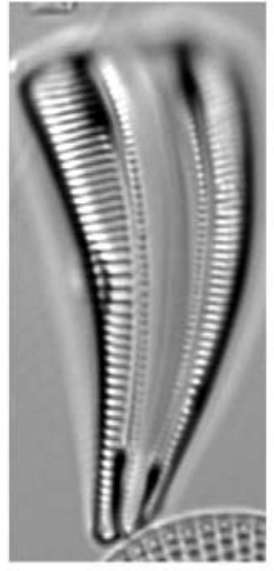

a
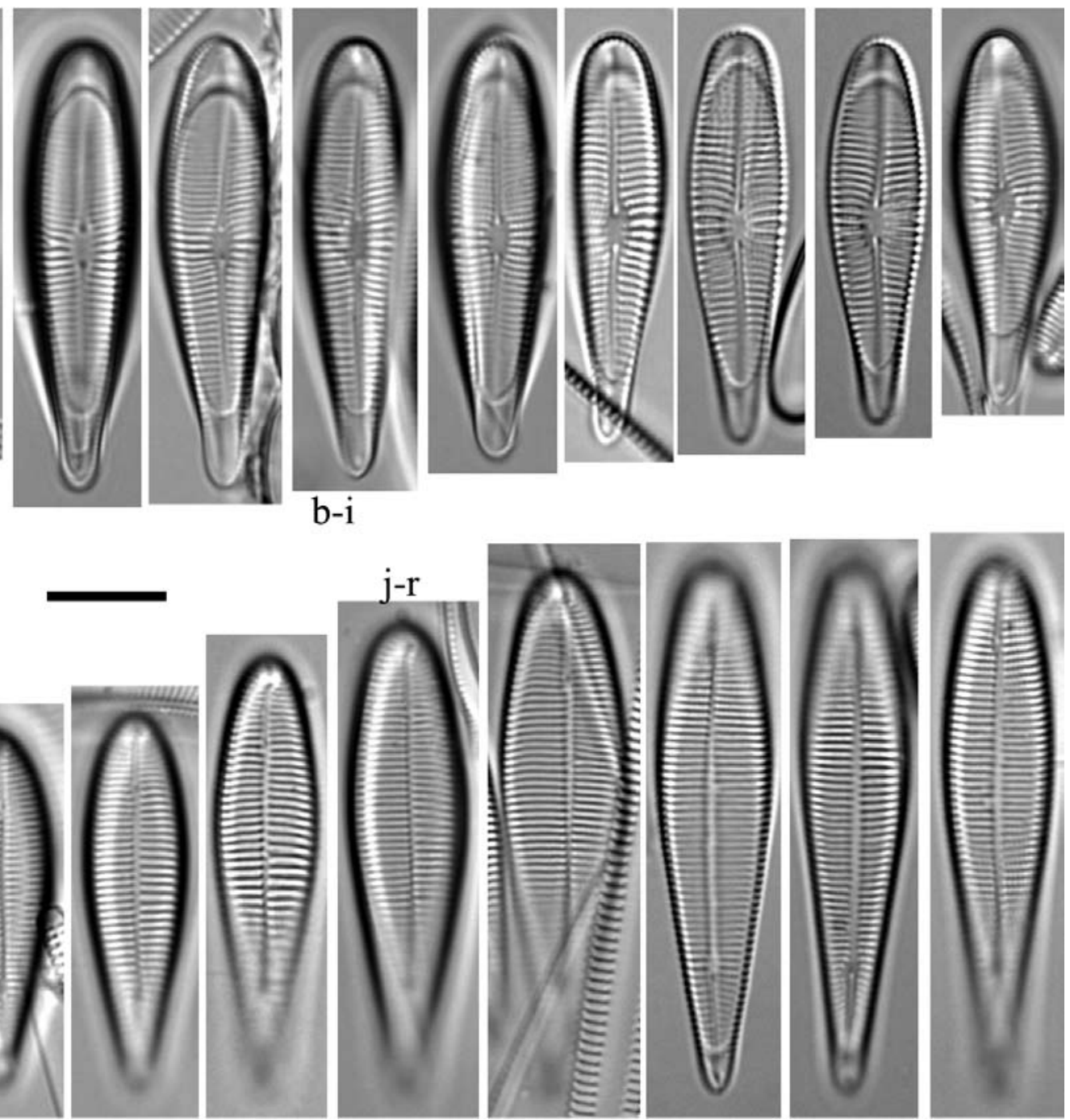

Figs 7a-r. Rhoicosphenia marina, LM, Le Havre, France: (7a) frustule in girdle view, (7b-i) diminution series of the concave $\mathrm{R}$-valve, (7j-r) diminution series of the convex D-valve. Scale bar $10 \mu \mathrm{m}$. 


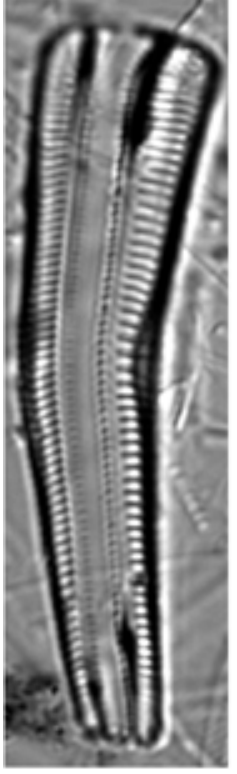

a
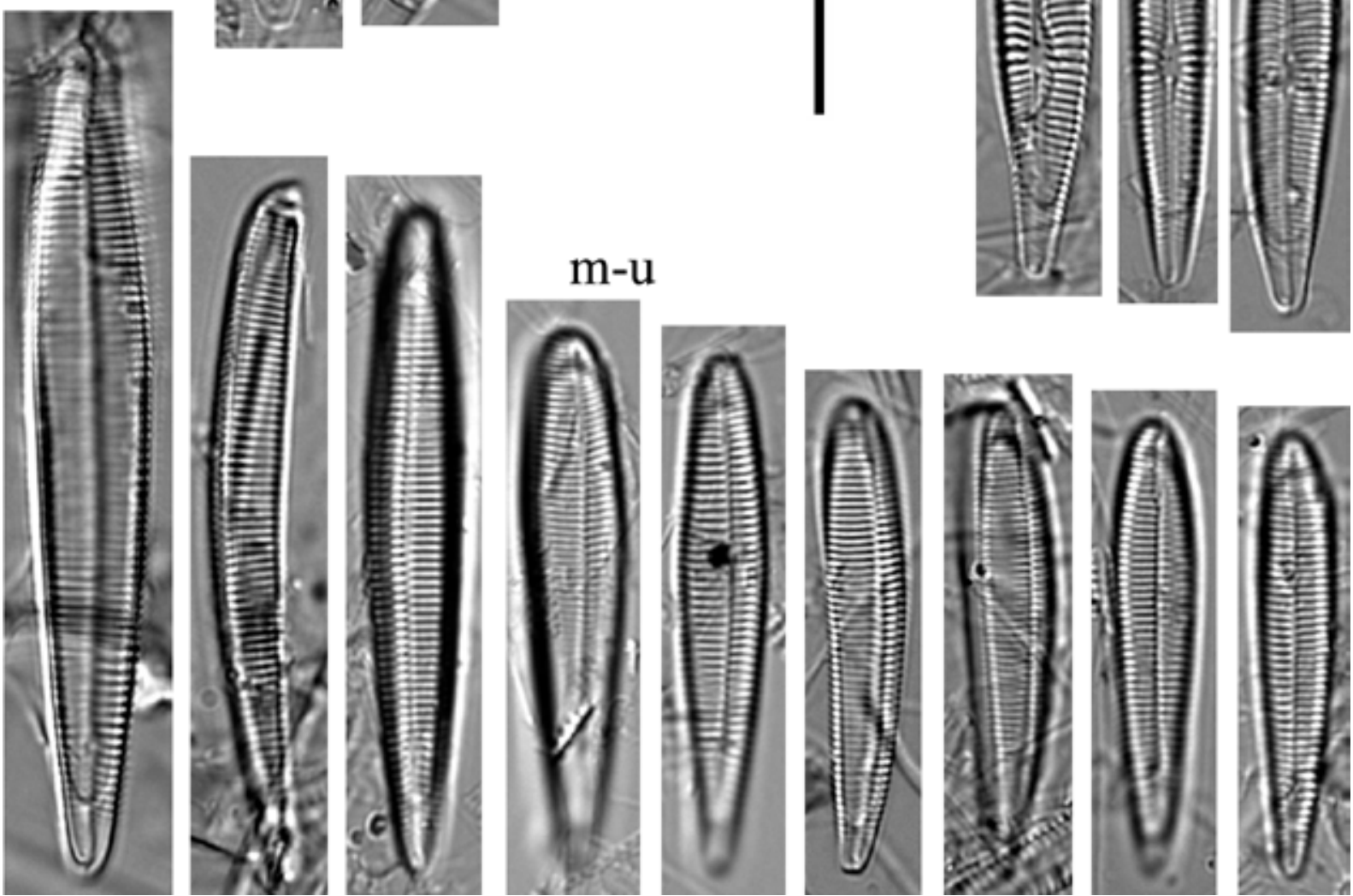

Figs 8a-u. Rhoicosphenia linearis, LM, type material, Jylland, Denmark: (8a) frustule in girdle view, (8b-1) diminution series of the concave R-valve, (8m-u) diminution series of the convex D-valve. Scale bar $10 \mu \mathrm{m}$. 

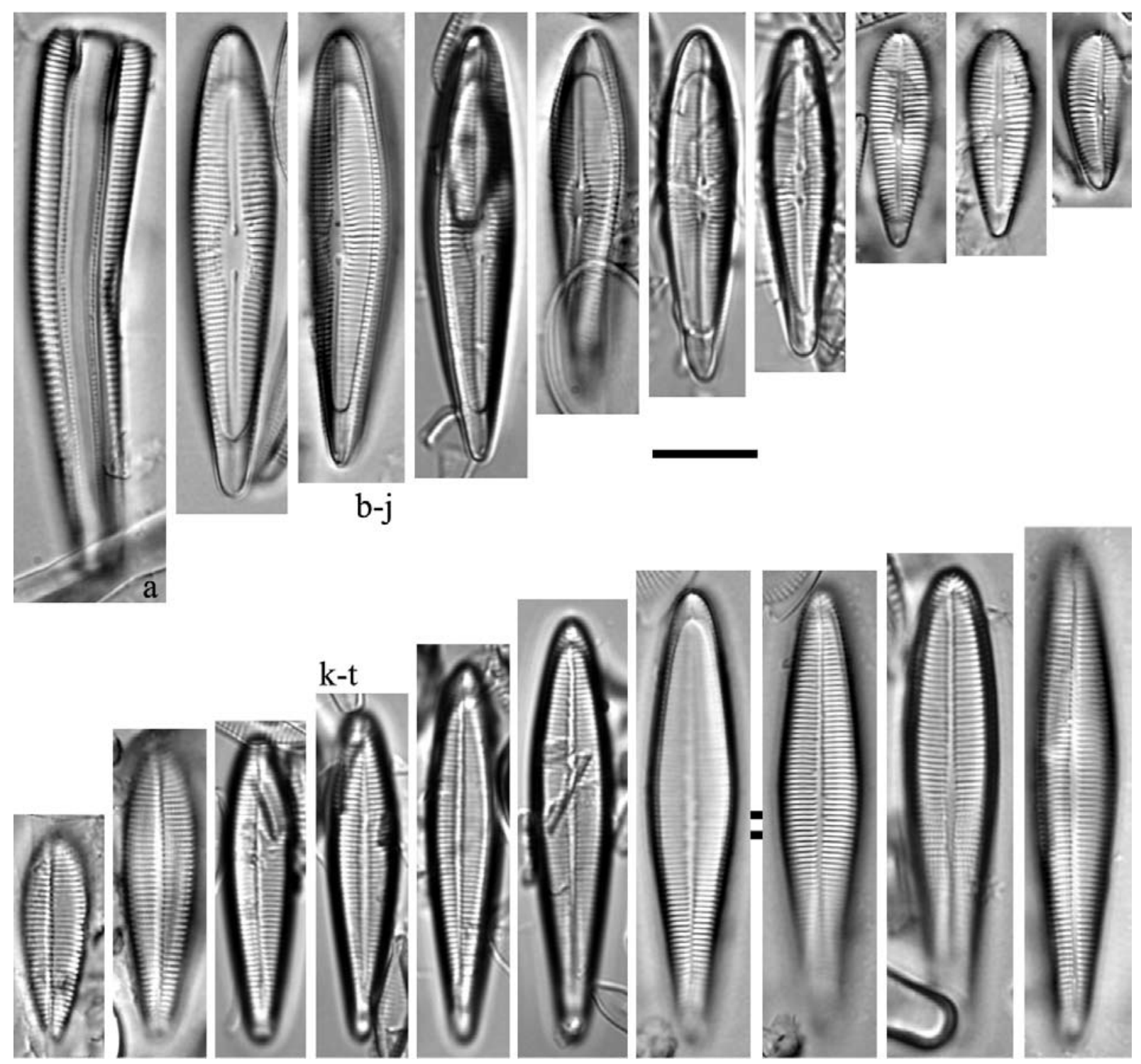

Figs 9a-t. Rhoicosphenia macedonica, LM, Lake Ohrid, Kaneo, macrophytes: (9a) frustule in girdle view, (9b-j) diminution series of the concave R-valve, $(9 \mathrm{k}-\mathrm{t})$ diminution series of the convex D-valve. Scale bar $10 \mu \mathrm{m}$. 

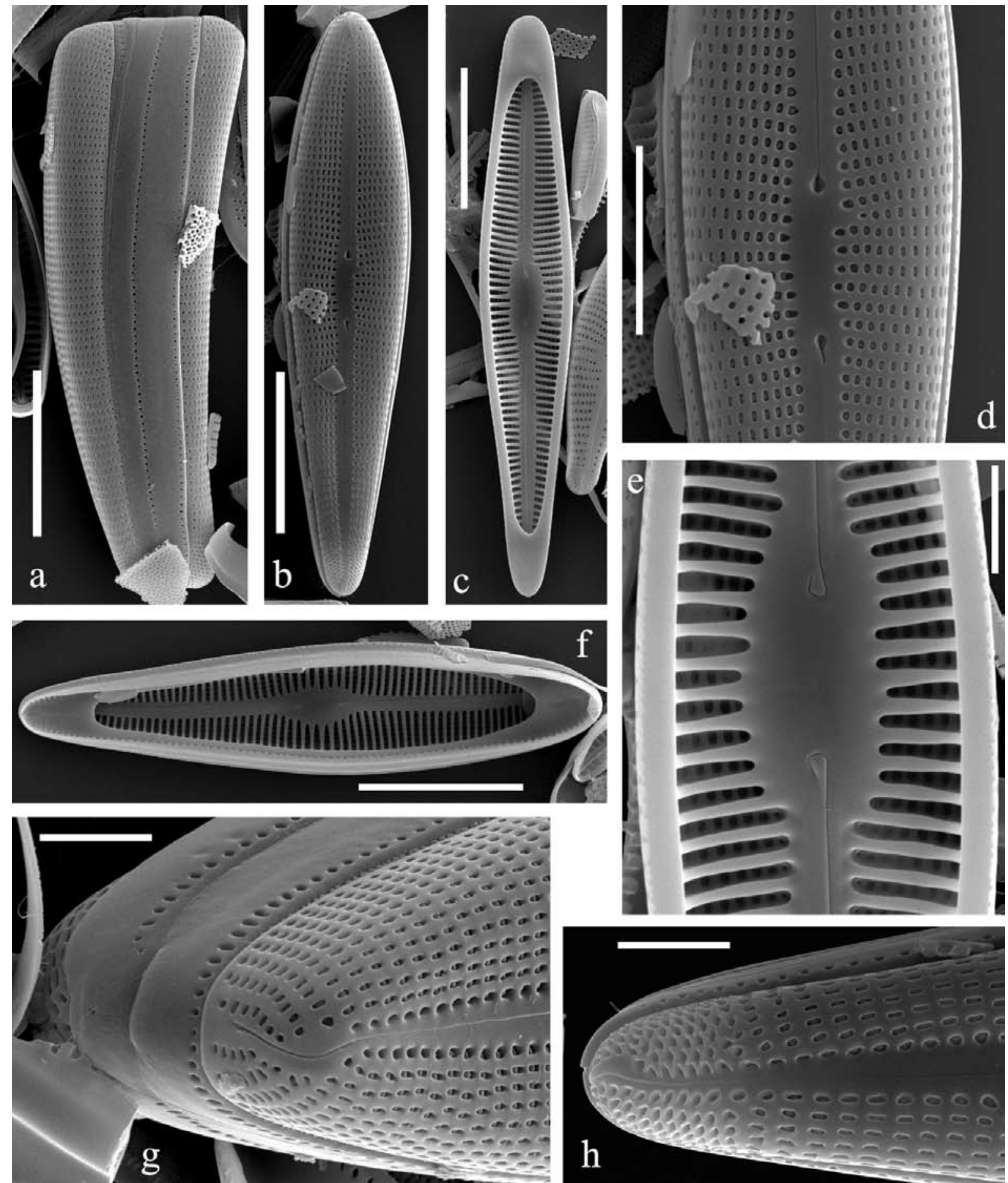

Figs 10a-h. Rhoicosphenia macedonica, SEM, frustule and concave R-valve: (10a) frustule in girdle view, (10b) external view of whole valve, (10c, 10f) internal view of whole valve, note the pseudoseptum (Fig. 10c) and the modified valvocopula (Fig. 10f) present on the valve poles, (10d) detail of valve centre from Fig. 10b showing the proximal raphe fissures expanded in drop-shaped central pores, (10e) internal view of valve centre showing the crook-shaped central fissures, $(10 \mathrm{~g})$ detail of the head pole showing the doubly curved distal raphe fissure, $(10 \mathrm{~h})$ detail of the base pole showing the doubly curved distal raphe fissure and the apical pore field, note the internal occlusion of the areolae, clearly seen on Figs 10d, 10g, 10h. Scale bar $10 \mu \mathrm{m}$ (Figs 10a-c, 10f), $5 \mu \mathrm{m}$ (Fig. 10d), $2 \mu \mathrm{m}$ (Figs 10e, 10g, 10h). 

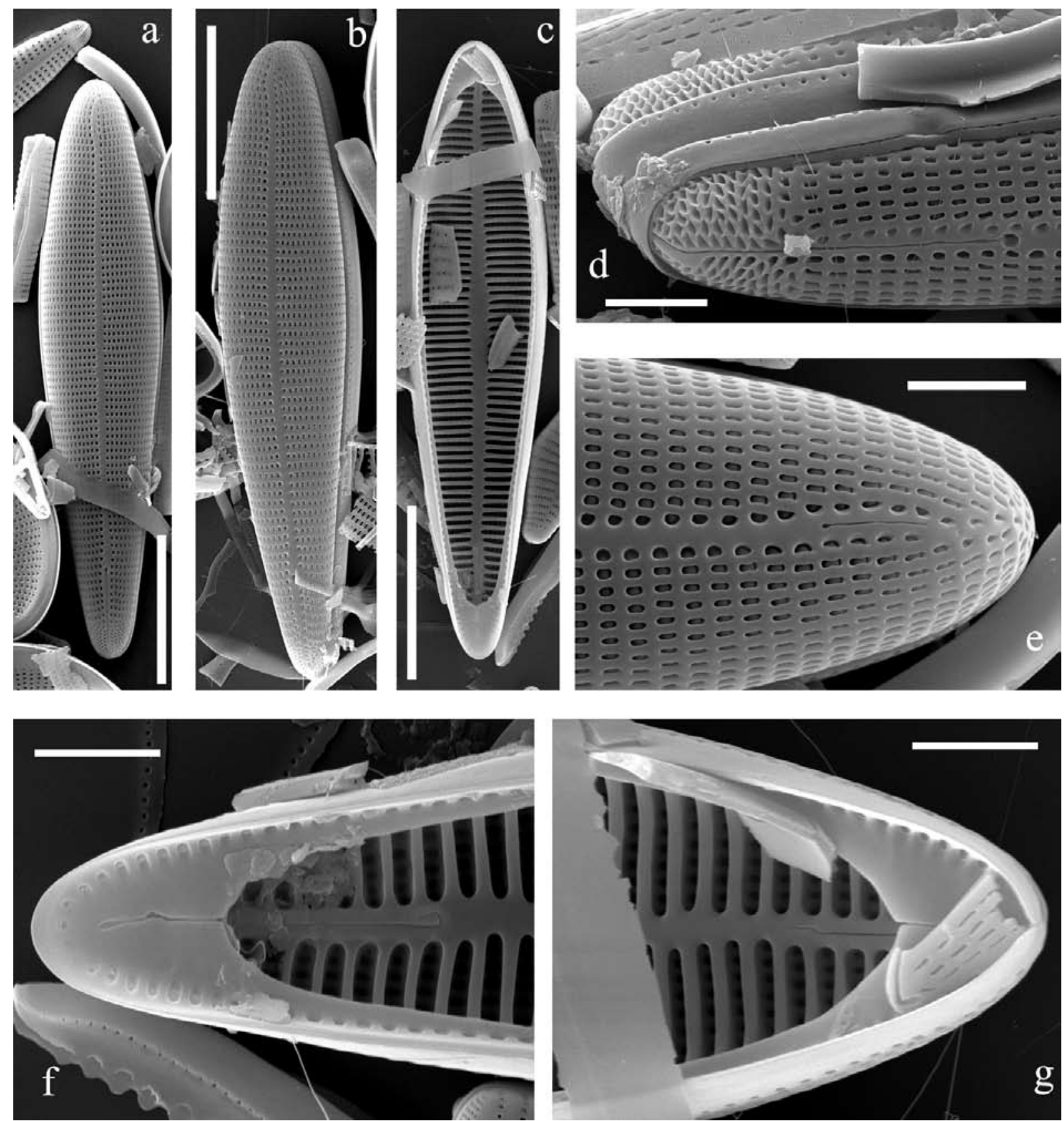

Figs 11a-g. Rhoicosphenia macedonica, SEM, convex D-valve: (11a, 11b) external view of whole valve, (11c) internal view of whole valve, modified valvocopula entirely covers the pseudoseptum, (11d) detail of base pole showing the slightly curved distal raphe fissure and apical pore field, (11e) detail of the head pole of Fig. 11a showing the short raphe branch, proximally weakly expanded in a small proximal pore, (11f) internal view of the base pole of Fig. 11c showing the crook-shaped proximal raphe fissure, $(11 \mathrm{~g})$ internal view of the head pole of Fig. 11c showing the curved proximal raphe fissure. Scale bar $10 \mu \mathrm{m}$ (Figs 11a-c), $2 \mu \mathrm{m}$ (Figs 11d-g). 

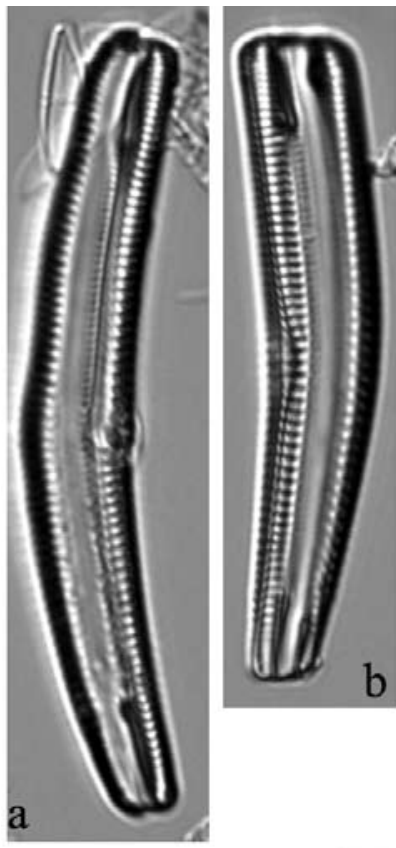

b
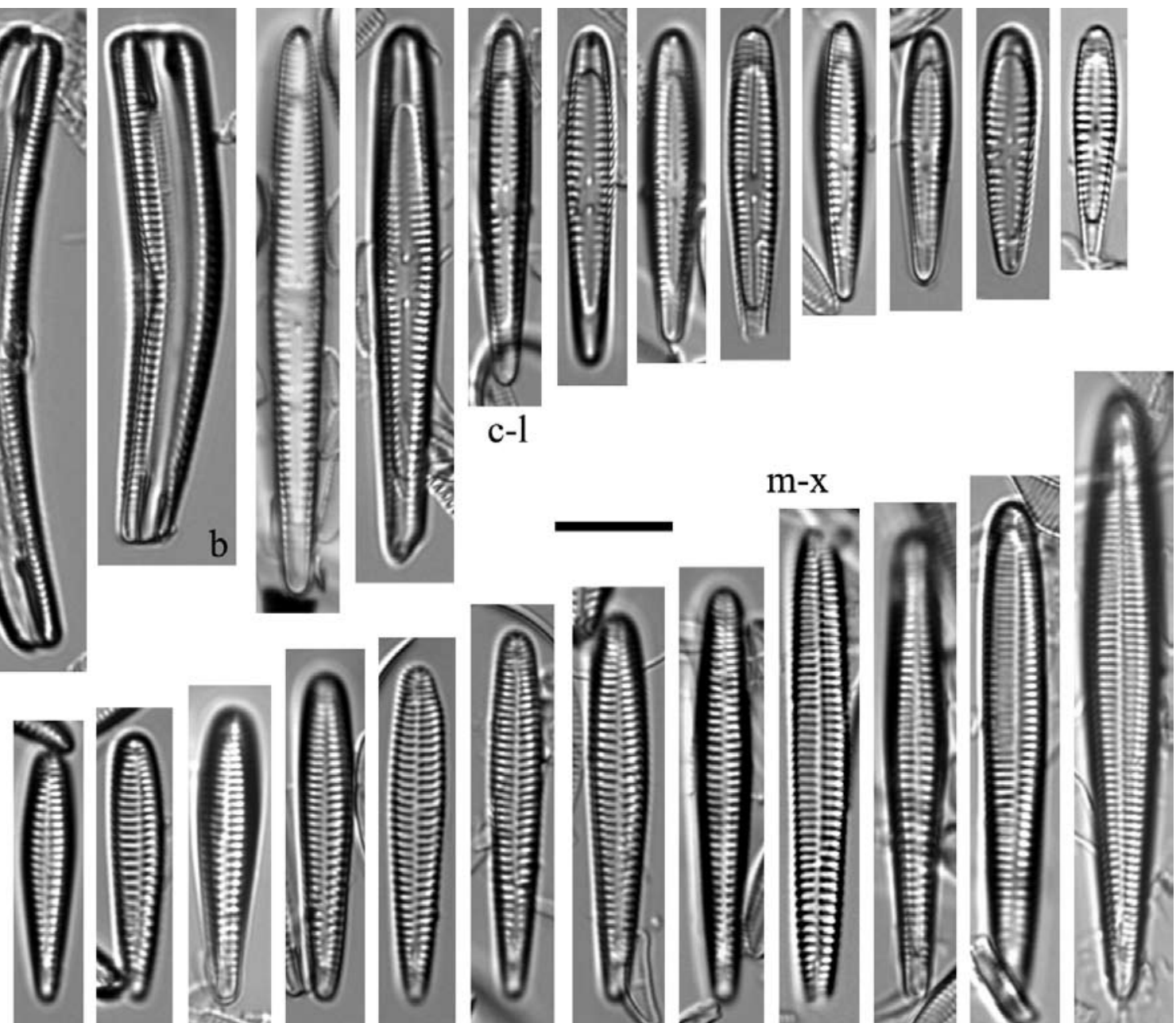

Figs 12a-x. Rhoicosphenia tenuis, LM, St. Naum Springs, Lake Ohrid, macrophytes: (12a, 12b) frustules in girdle view, (12c-1) diminution series of the concave R-valve, $(12 \mathrm{~m}-\mathrm{x})$ diminution series of the convex D-valve. Scale bar $10 \mu \mathrm{m}$. 

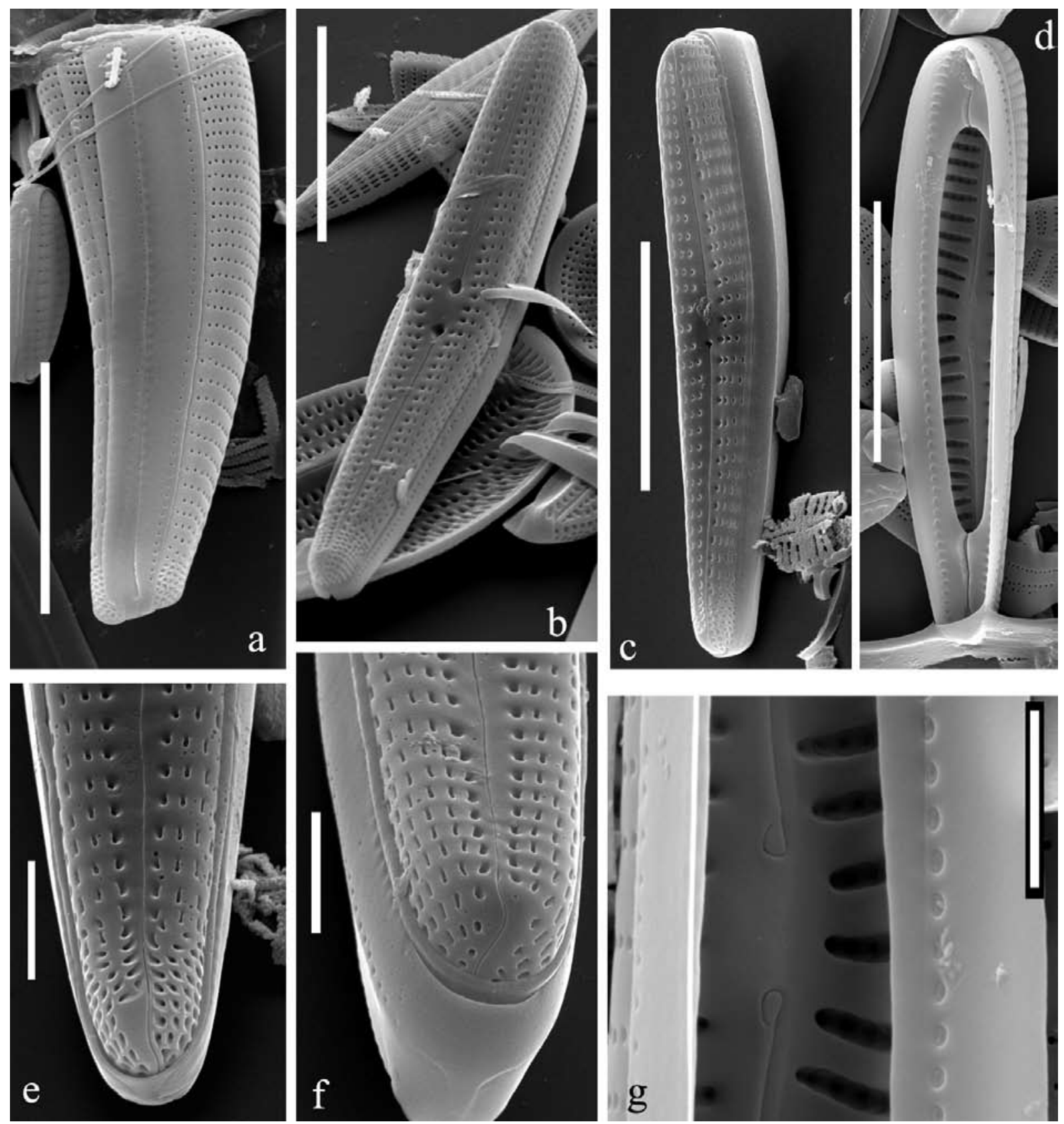

Figs 13a-g. Rhoicosphenia tenuis, SEM, frustule and concave R-valve: (13a) frustule in girdle view, each girdle band bears a row of round poroids. The position of poroids does not correspond with the mantle striae, $(13 \mathrm{~b}, 13 \mathrm{c})$ external view of whole valves, (13d) internal view of whole valve, the valvocopula entirely covers the pseudoseptum and bears a single row of poroids which are internally occluded, (13e) detail of the base pole showing the doubly curved distal raphe fissure and apical pore field, (13f) detail of the head pole showing the doubly curved distal raphe fissure, (13g) internal view of the valve centre showing the crook-shaped central fissures. Scale bar $10 \mu \mathrm{m}$ (Figs 13a-d), $2 \mu \mathrm{m}$ (Figs 13e-g). 

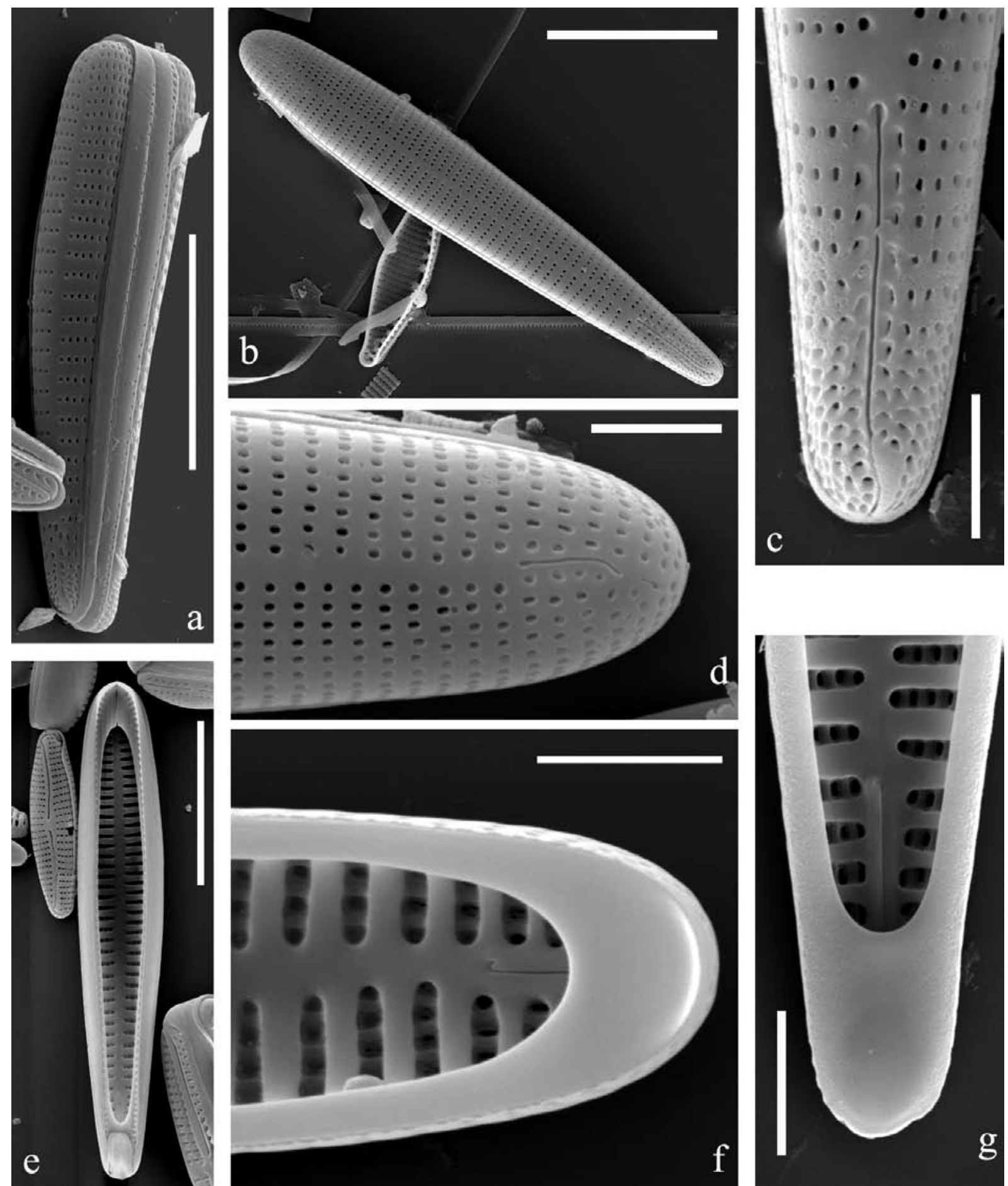

Figs 14a-g. Rhoicosphenia tenuis, SEM, convex D-valve: (14a, 14b) external view of whole valve, (14c) detail of the base pole showing the slightly curved distal raphe fissure and apical pore field, (14d) detail of the head pole showing the short raphe branch, proximally the raphe branch terminates with a small proximal pore, while distally it is bent, (14e) internal view of the whole valve and modified valvocopula, (14f) internal view of the head pole showing the bent proximal raphe fissure and pseudoseptum, $(14 \mathrm{~g})$ internal view of the base pole showing the bent proximal raphe fissure and pseudoseptum. Scale bar 10 $\mu \mathrm{m}$ (Figs 14a, 14b, 14e), $2 \mu \mathrm{m}$ (Figs 14c, 14d, 14f, 14g). 


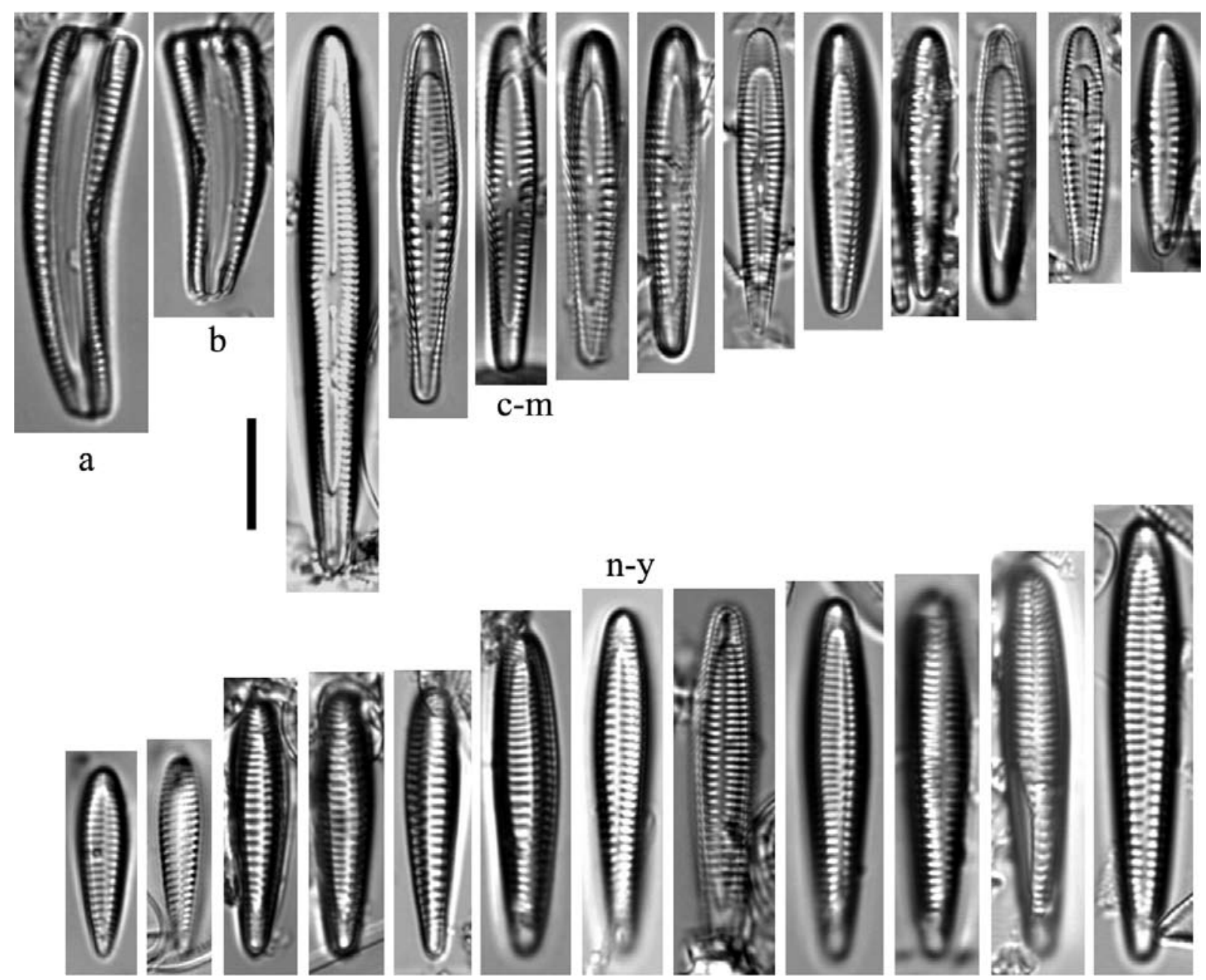

Figs 15a-y. Rhoicosphenia baicalensis, LM, Lake Baikal, Maloe More, sediment: (15a, 15b) frustules in girdle view, $(15 \mathrm{c}-\mathrm{m})$ diminution series of the concave R-valve, (15n-y) diminution series of the convex D-valve. Scale bar $10 \mu \mathrm{m}$. 

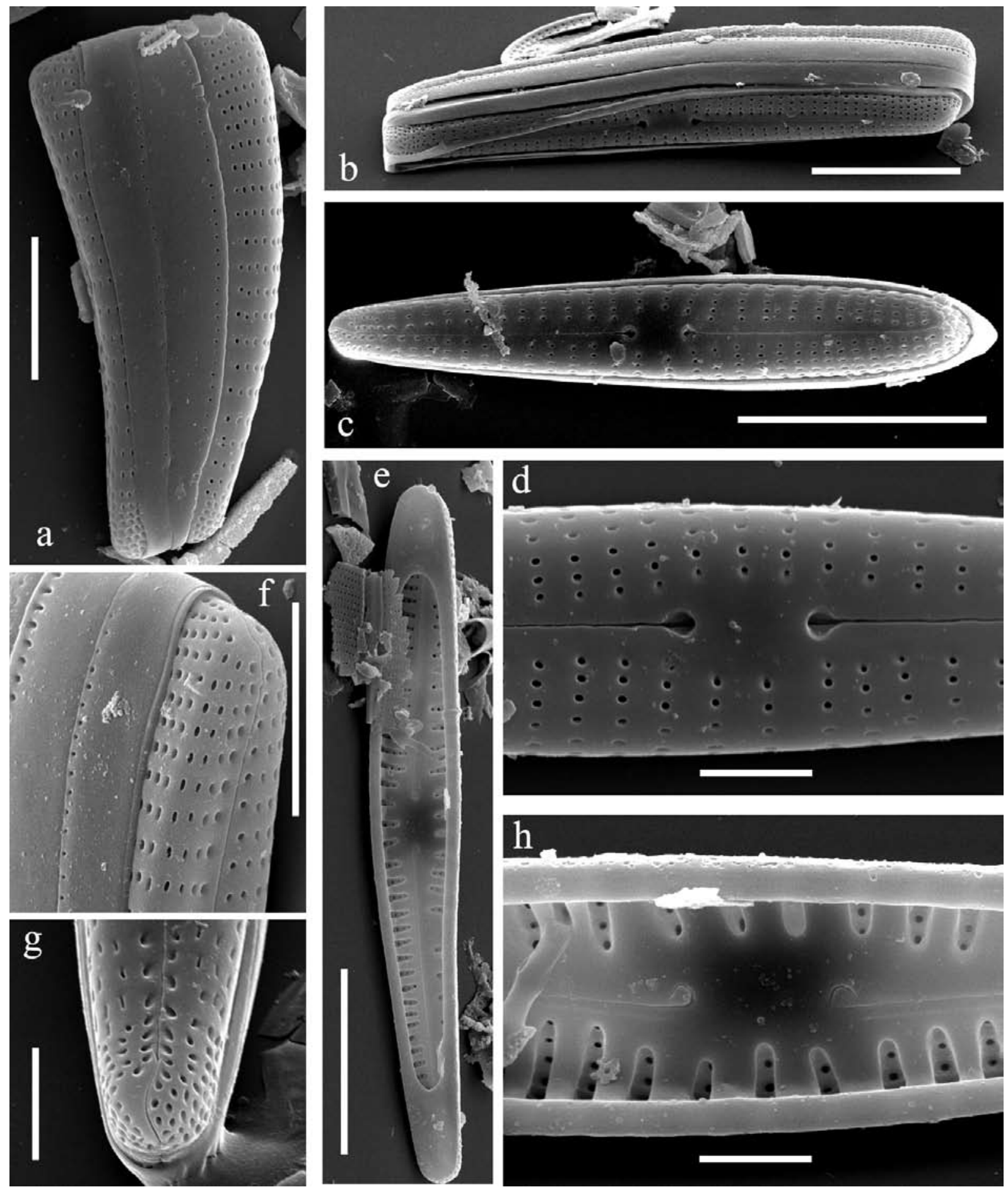

Figs 16a-h. Rhoicosphenia baicalensis, SEM, frustule and concave R-valve: (16a) frustule in girdle view, (16b, 16c) external view of whole valve, (16d) detail of valve centre showing the drop-shaped central pores and circular areolae, (16e) internal view of whole valve; note the large pseudoseptum present on the poles, (16f) detail of the head pole showing the doubly curved distal raphe fissure and the single row of poroids on the pars exterior of each copula, $(16 \mathrm{~g})$ detail of the base pole showing the strongly doubly curved distal raphe fissure and apical pore field; note the asymmetrical hyaline area present at the base pole opposite to curvature of the distal raphe fissure, (16h) internal view of the valve centre showing the crook-shaped central fissures. Scale bar $10 \mu \mathrm{m}$ (Figs 16b, 16c, 16e), $5 \mu \mathrm{m}$ (Figs 16a, 16f), $2 \mu \mathrm{m}$ (Figs 16d, 16g, 16h). 

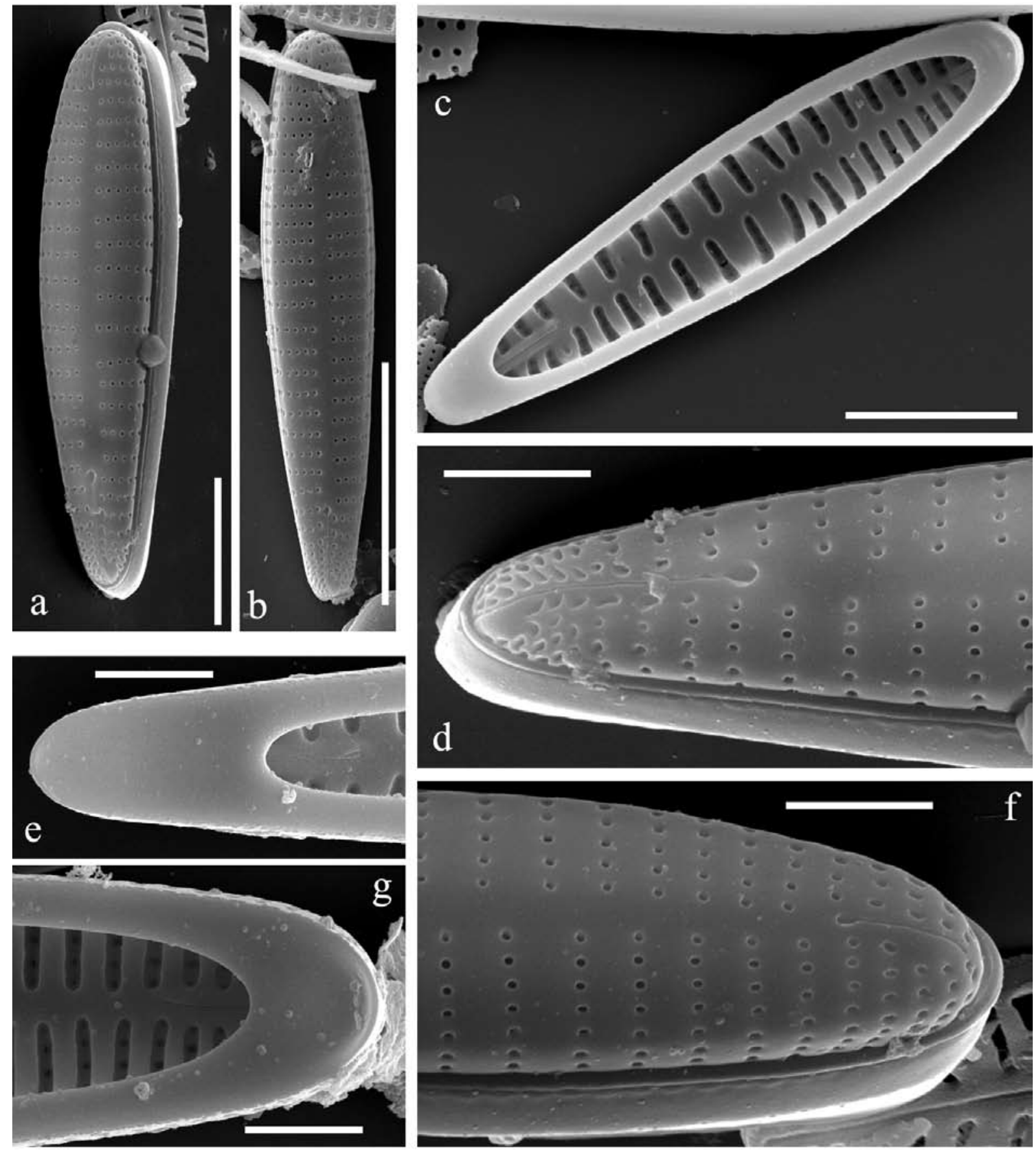

Figs 17a-g. Rhoicosphenia baicalensis, SEM, convex D-valve: (17a, 17b) external view of whole valve, (17c) internal view of whole valve and pseudoseptum, (17d) detail of the base pole showing the slightly curved distal raphe fissure and apical pore field, (17e) internal view of base pole showing the crook-shaped proximal raphe fissure, (17f) detail of the head pole showing the short raphe branch, $(17 \mathrm{~g})$ internal view of the head pole showing the crook-shaped proximal raphe fissure, proximally, the raphe branch terminates with a small proximal pore. Scale bar $10 \mu \mathrm{m}$ (Fig. 17b), $5 \mu \mathrm{m}$ (Figs 17a, 17c), $2 \mu \mathrm{m}$ (Figs 17d-g). 


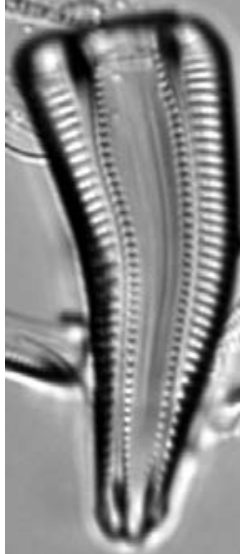

a
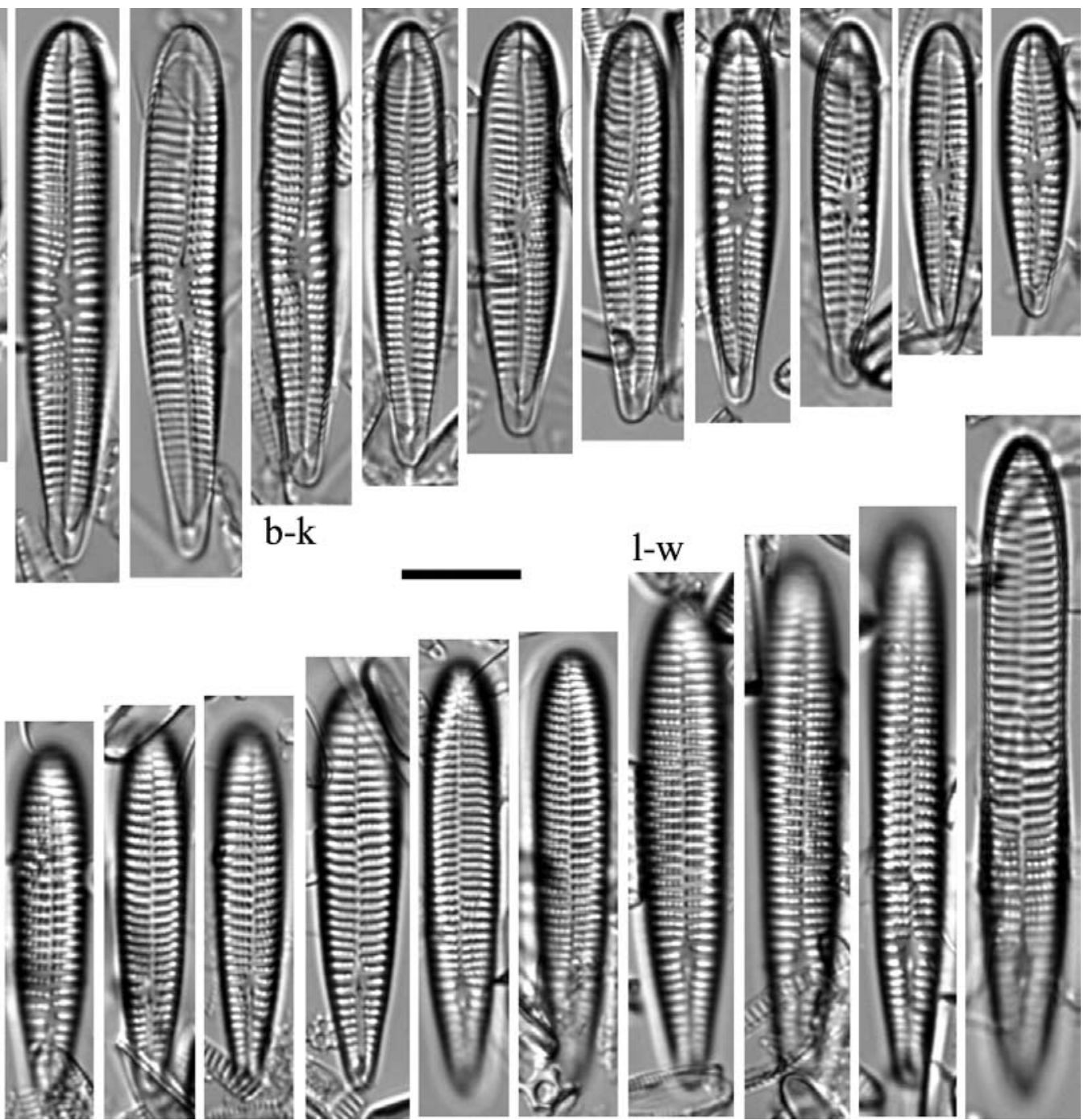

Figs 18a-w. Rhoicosphenia flexa, LM, Capetown, South Africa: (18a) frustule in girdle view, (18b-k) diminution series of the concave R-valve, (181-w) diminution series of the convex D-valve. Scale bar $10 \mu \mathrm{m}$. 

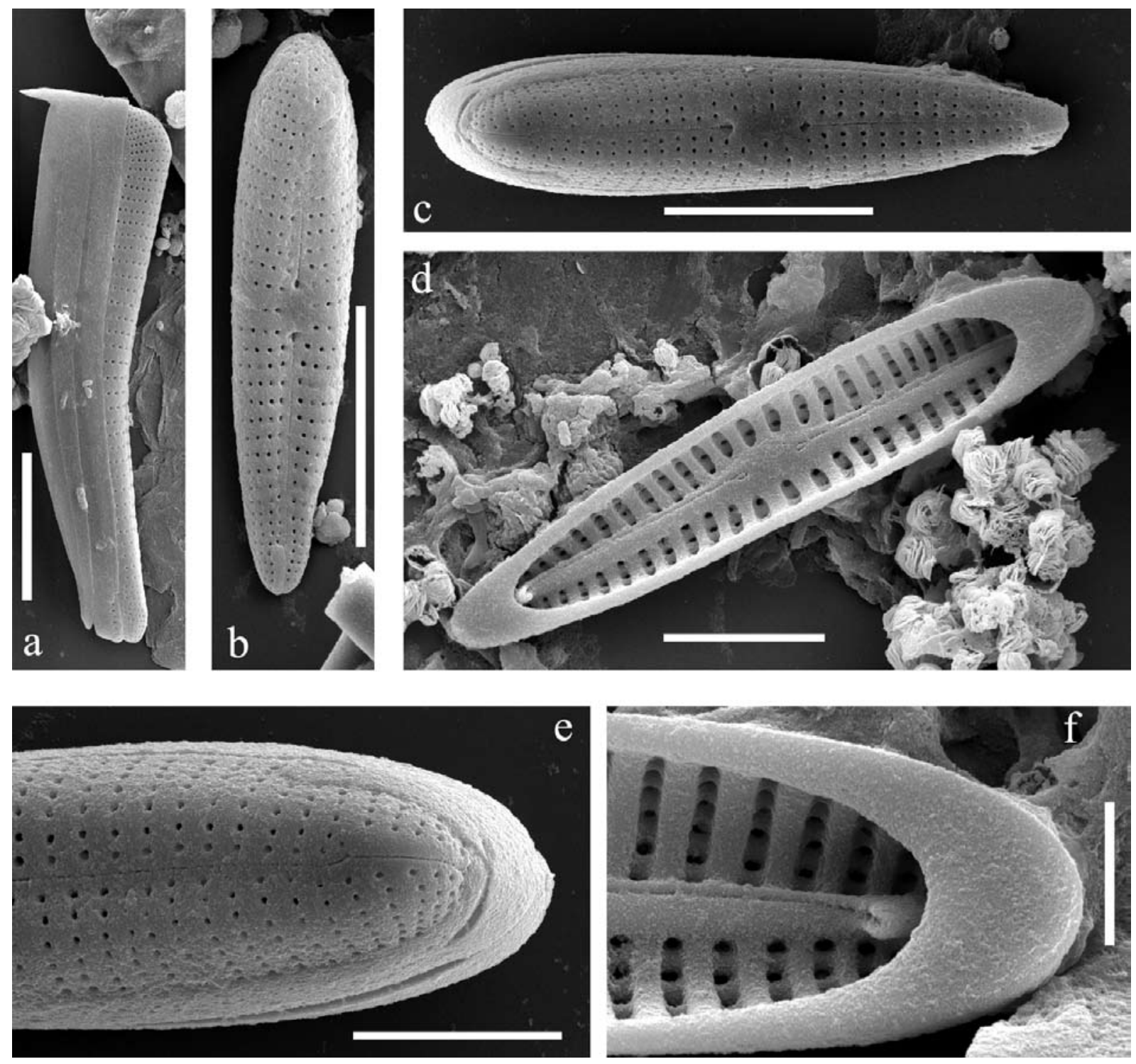

Figs 19a-f. Rhoicosphenia flexa, SEM, frustule and concave R-valve: (19a) frustule in girdle view, (19b, 19c) external view of whole valves, (19d) internal view of whole valve and pseudoseptum, (19e) detail of the head pole of Fig. 19c showing the weakly curved distal raphe fissure, (19f) internal view of the head pole of Fig. 19f showing the small elevated helictoglossa. Scale bar $10 \mu \mathrm{m}$ (Figs 19a-c), $5 \mu \mathrm{m}$ (Figs 19d, 19e), $2 \mu \mathrm{m}$ (Fig. 19f). 

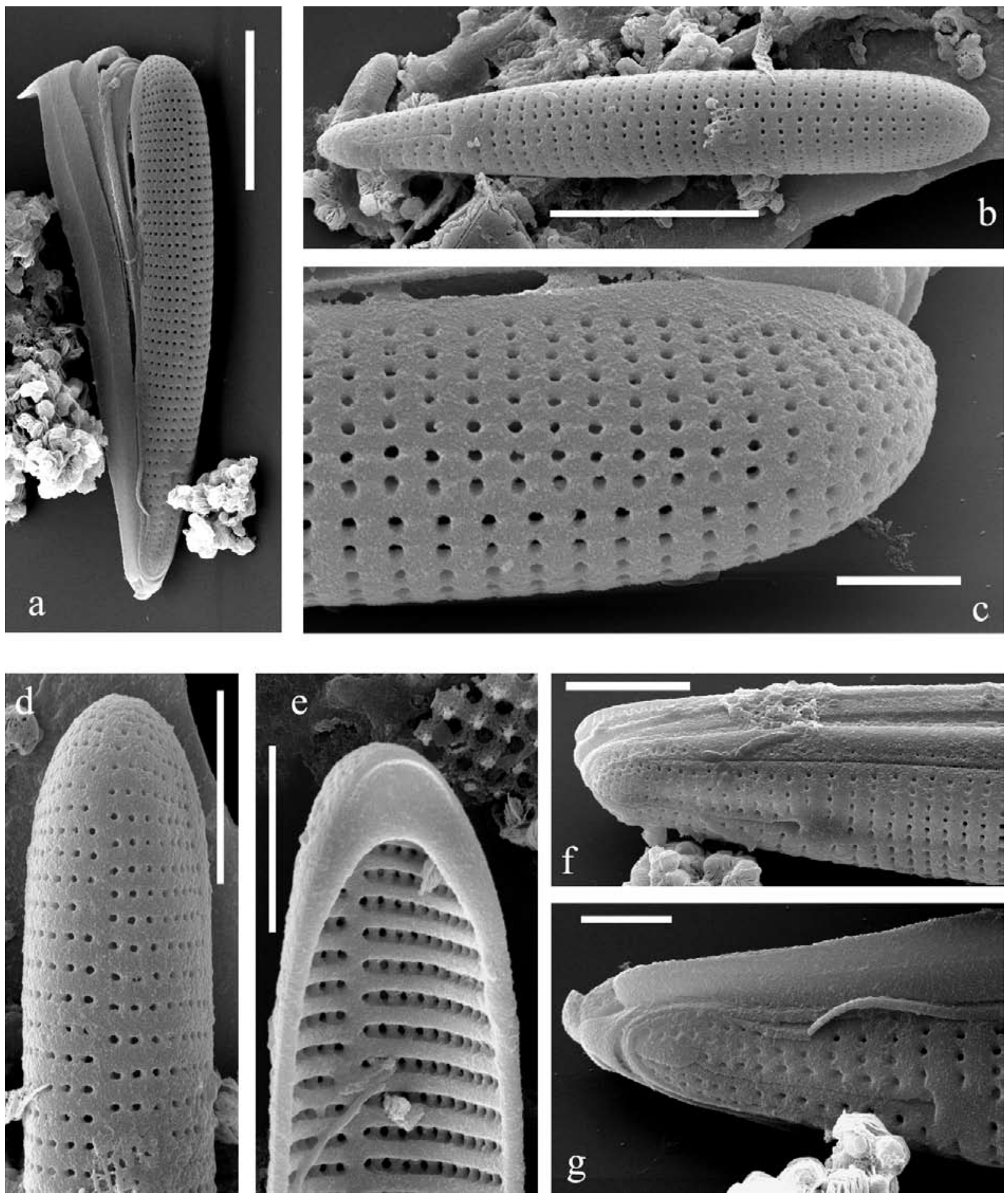

Figs 20a-g. Rhoicosphenia flexa, SEM, convex D-valve: (20a, 20b) external view of whole valve, (20c, 20d) detail of the head pole. Note that the raphe slit is absent at the head pole, (20e) internal view of the head pole and pseudoseptum, $(20 \mathrm{f}, 20 \mathrm{~g})$ detail of the base pole showing the slightly curved distal raphe fissure, note the absence of an apical pore field. Scale bar $10 \mu \mathrm{m}$ (Figs 20a, 20b), $2 \mu \mathrm{m}$ (Figs 20c, 20g), $5 \mu \mathrm{m}$ (Figs 20d-f). 

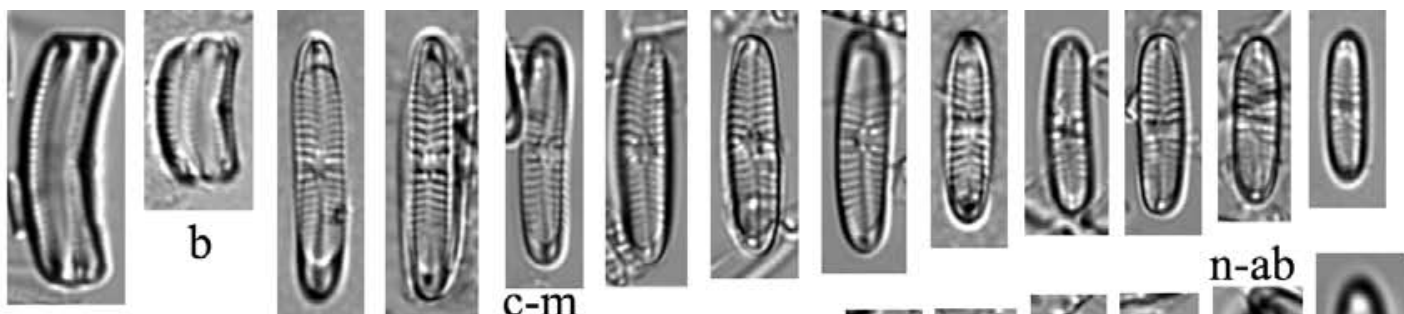

a

$\mathrm{c}-\mathrm{m}$
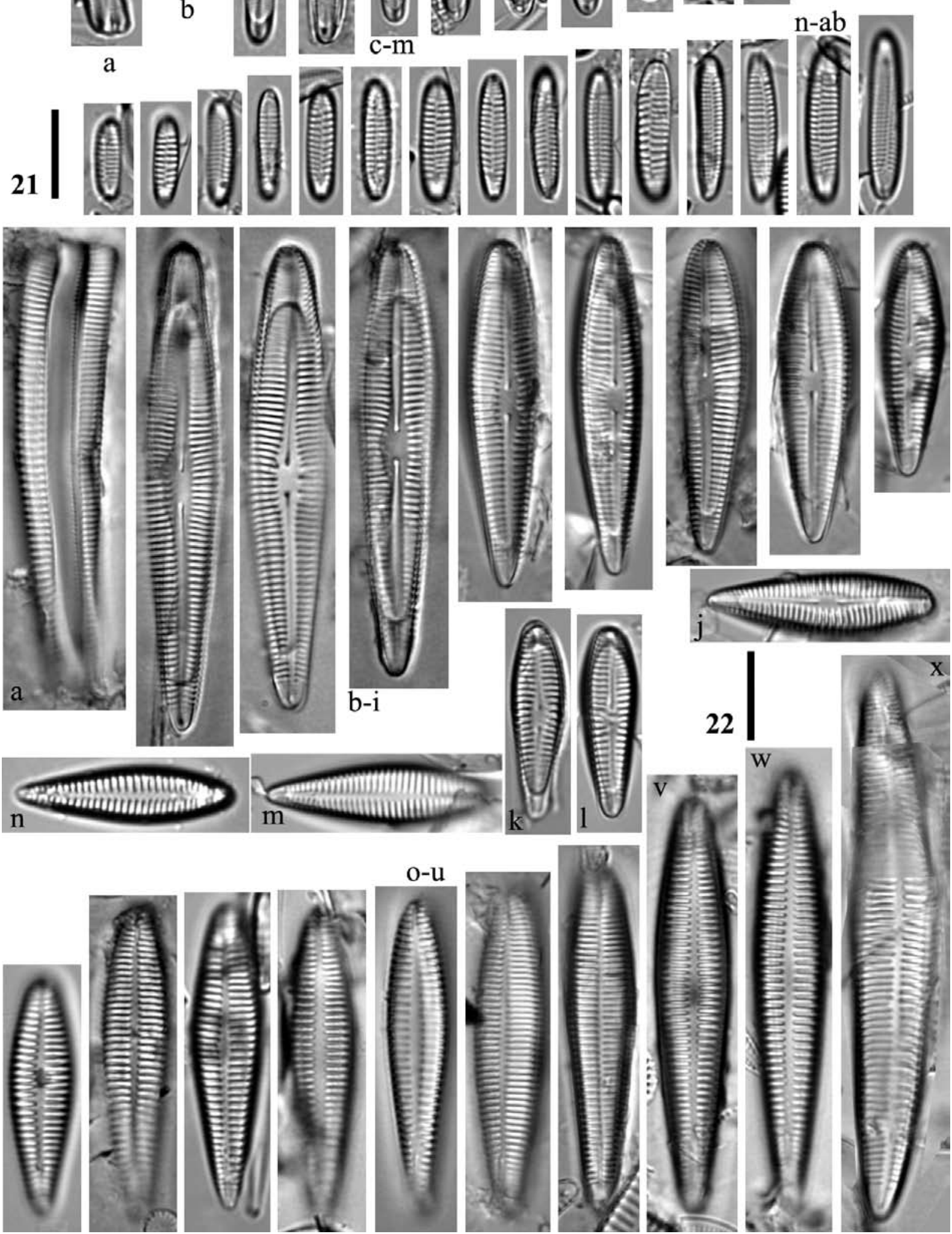

Figs 21a-ab. Rhoicosphenia genuflexa, LM, Capetown, South Africa: (21a, b) frustules in girdle view, (21c-m) diminution series of the concave R-valve, (21n-ab) diminution series of the convex D-valve. Scale bar $10 \mu \mathrm{m}$.

Figs 22a-x. Rhoicosphenia lacustris, LM, Lake Dojran, Macedonia, macrophytes: (22a) frustule in girdle view, (22b-1) diminution series of the concave R-valve, $(22 \mathrm{~m}-\mathrm{x})$ diminution series of the convex D-valve. Scale bar $10 \mu \mathrm{m}$. 

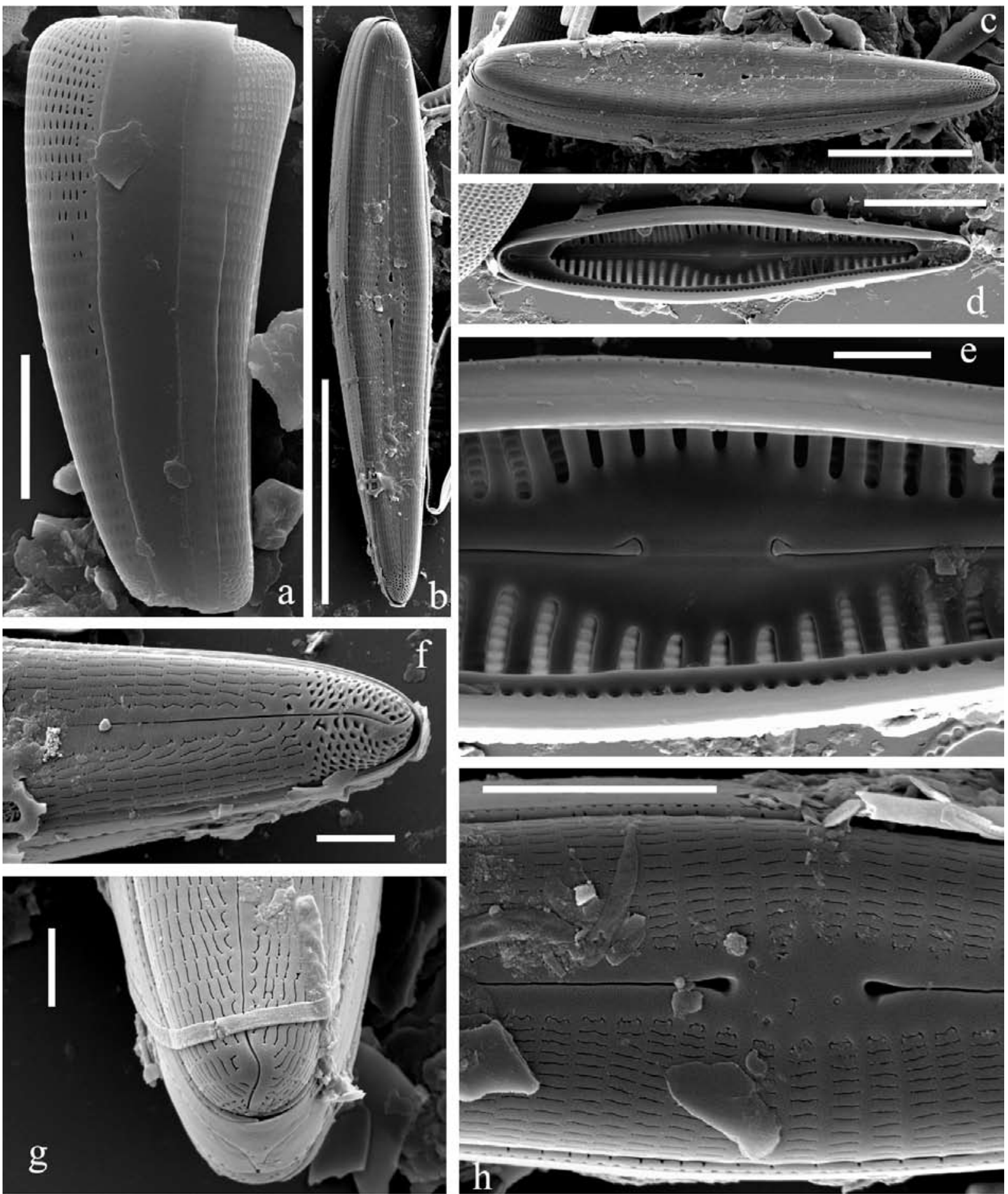

Figs 23a-h. Rhoicosphenia lacustris, SEM, frustule and concave R-valve: (23a) frustule in girdle view, (23b, 23c) external view of whole valves, (23d) internal view of whole valve and pseudoseptum, (23e) detail of valve centre of Fig. 23d showing the crook-shaped central raphe fissures, (23f) detail of the base pole of Fig. $23 \mathrm{~b}$ showing the apical pore field and doubly curved distal raphe ending, (23g) detail of the head pole showing the doubly curved distal raphe fissure, (23h) detail of valve centre showing the drop-shaped central pores. Scale bar $5 \mu \mathrm{m}$ (Figs 23a, h), $20 \mu \mathrm{m}$ (Fig. 23b), $10 \mu \mathrm{m}$ (Figs $23 \mathrm{c}, \mathrm{d}$ ), $2 \mu \mathrm{m}$ (Figs $23 \mathrm{e}-\mathrm{g})$. 

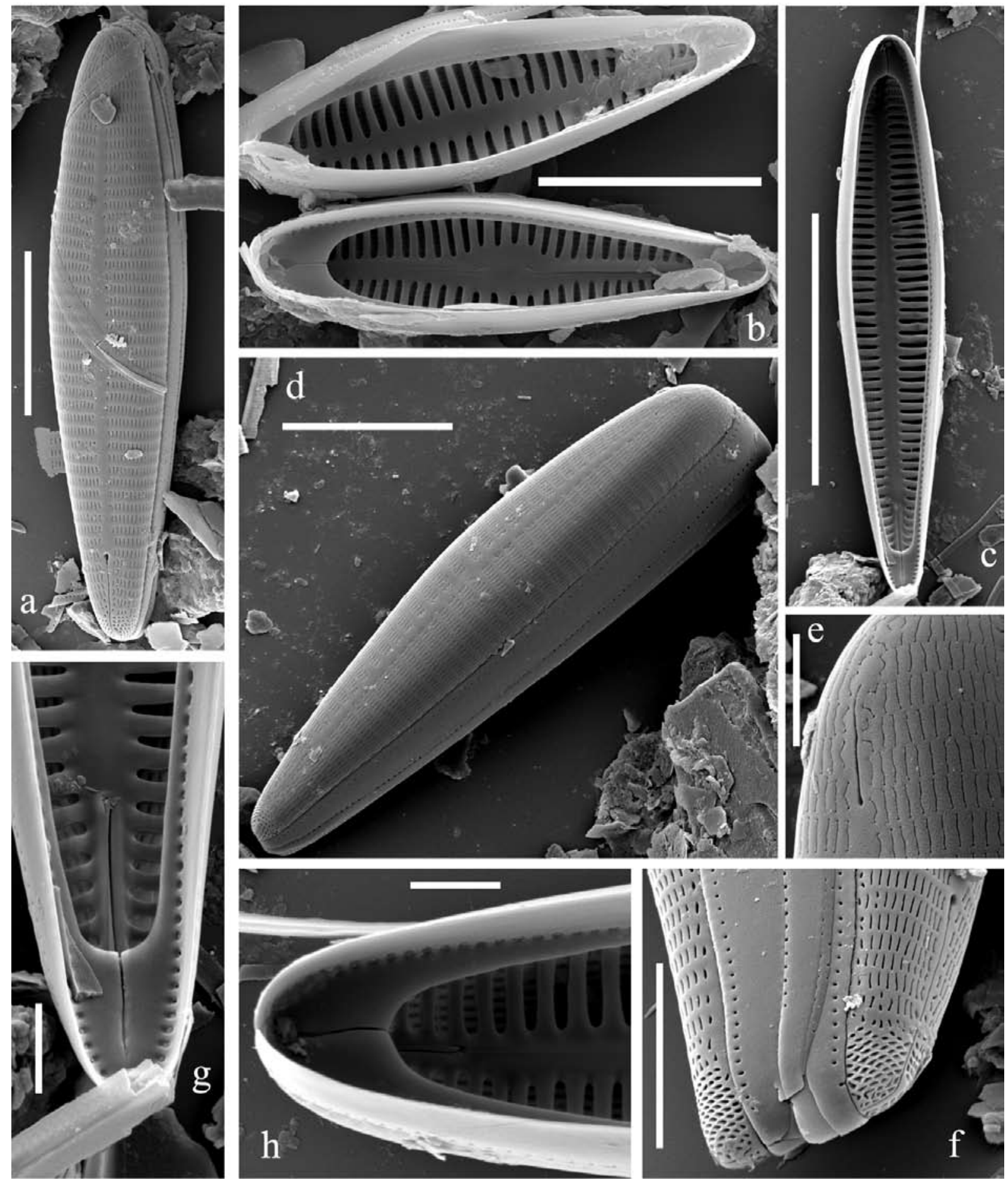

Figs 24a-g. Rhoicosphenia lacustris, SEM, convex D-valve: (24a, d) external view of whole valve, (24b) internal view of $\mathrm{R}$-and D-valves and adjusting valvocopulae, (24c) internal view of whole valve, (24e) detail of the head pole showing the short raphe branch, (24f) detail of the base pole showing the distal raphe fissure and the apical pore field, $(24 \mathrm{~g})$ internal view of the base pole showing the crooked-fissure, $(24 \mathrm{~h})$ internal view of the head pole showing the crooked-fissure proximal raphe fissure and open valvocopula. Scale bar $10 \mu \mathrm{m}$ (Figs 24a, b, d), $20 \mu \mathrm{m}$ (Fig. 24c), $2 \mu \mathrm{m}$ (Figs 24e, g, h), $5 \mu \mathrm{m}$ (Fig. 24f). 

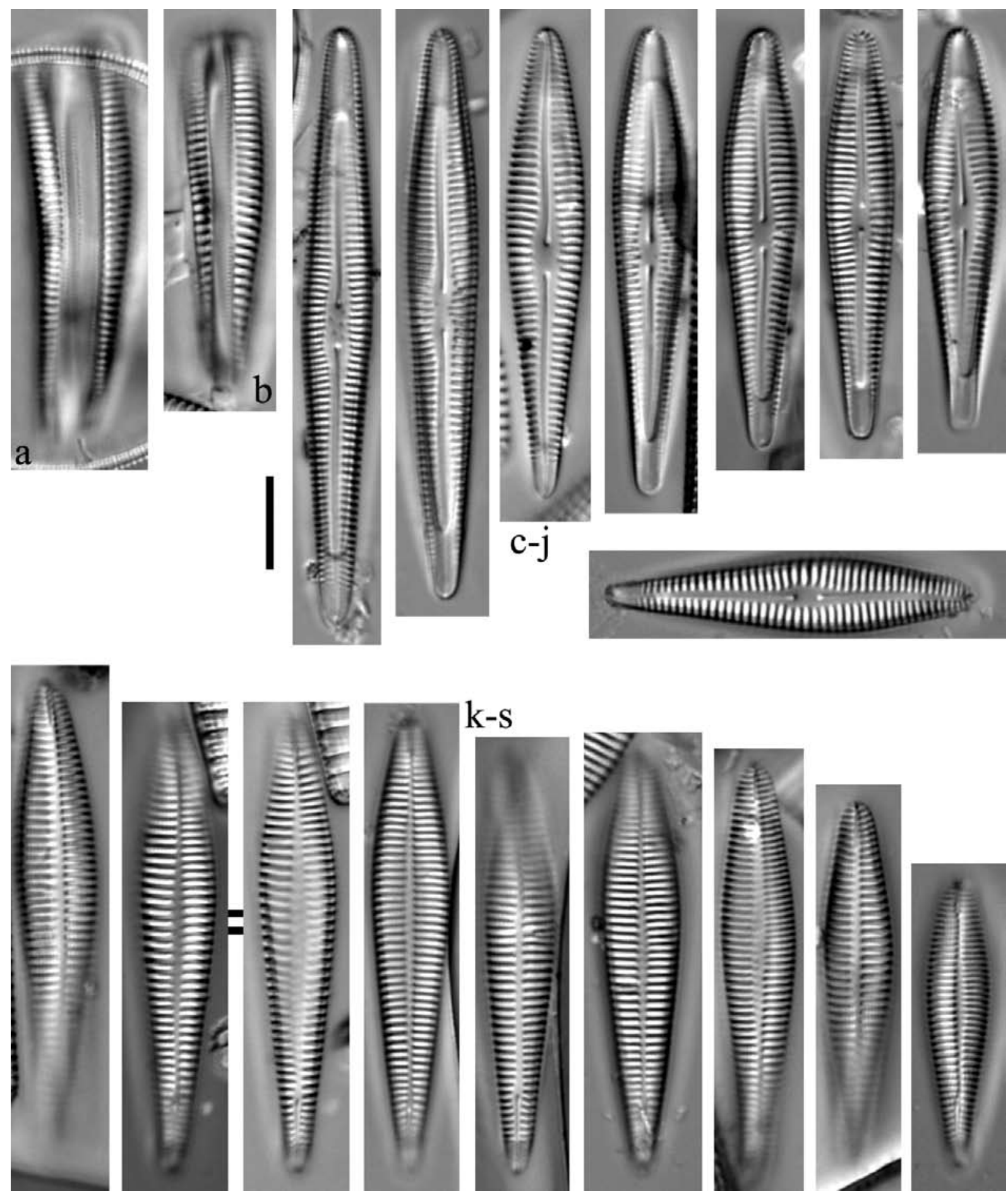

Figs 25a-s. Rhoicosphenia affinis, LM, Hai Nan China: $(25 \mathrm{a}, 25 \mathrm{~b})$ frustules in girdle view, $(25 \mathrm{c}-\mathrm{j})$ diminution series of the concave R-valve, $(25 \mathrm{k}-\mathrm{s})$ diminution series of the convex D-valve. Scale bar $10 \mu \mathrm{m}$. 

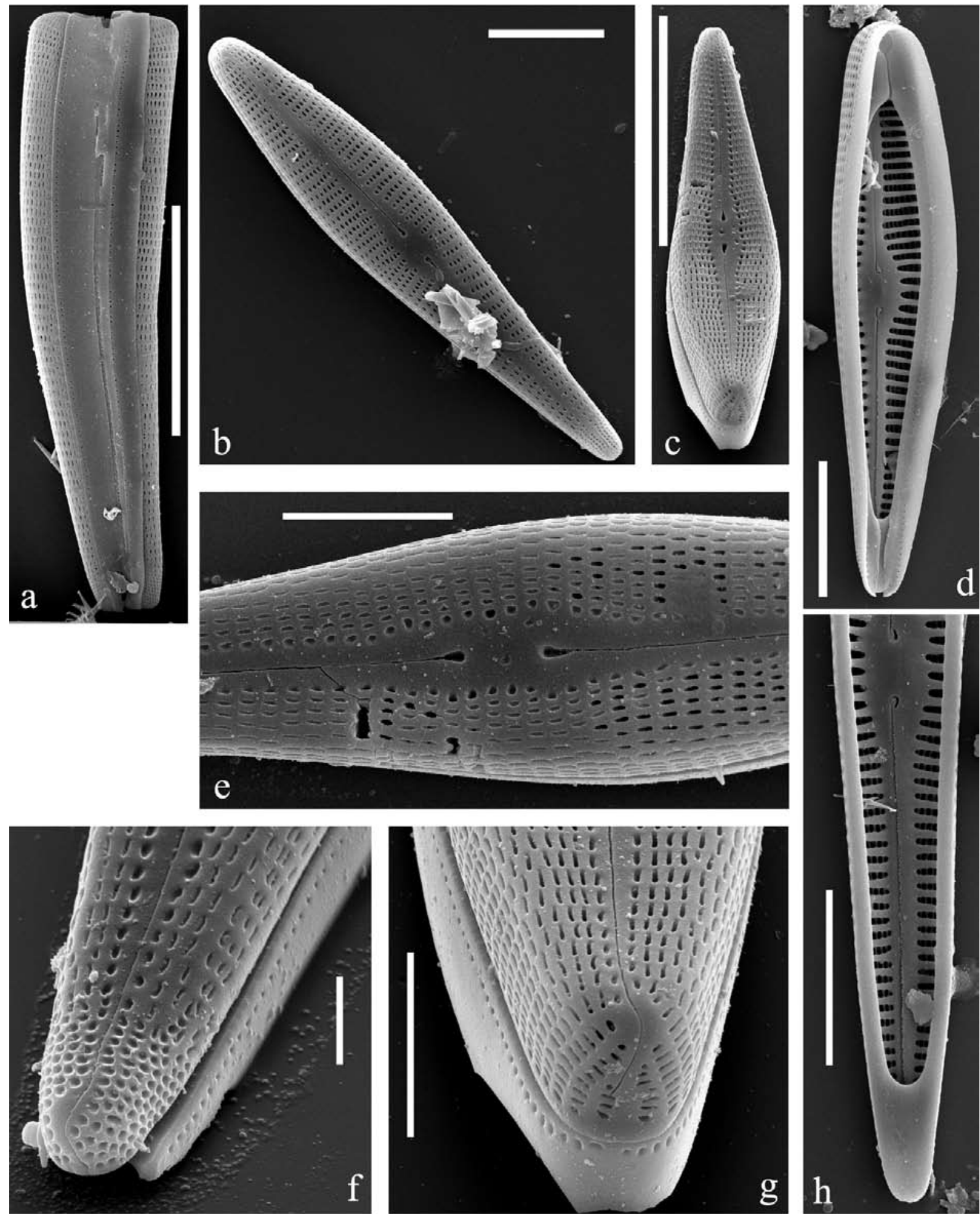

Figs 26a-h. Rhoicosphenia affinis, SEM, frustule and concave R-valve: (26a) frustule in girdle view, (26b, 26c) external view of whole valves, (26d) internal view of whole valve with valvocopula, (26e) detail of valve centre of Fig. 26c showing the drop-shaped central pores, (26f) detail of the base pole showing the strongly doubly curved distal raphe fissure and apical pore field, (26g) detail of the head pole of Fig. 26c showing the doubly curved distal raphe fissure, (26h) internal view of the valve centre showing the crook-shaped central fissures and pseudoseptum. Scale bar $20 \mu \mathrm{m}$ (Figs 26a, 26c), $10 \mu \mathrm{m}$ (Figs 26b, 26d, 26h), $5 \mu \mathrm{m}$ (Figs 26e, 26g), $2 \mu \mathrm{m}$ (Fig. 26f). 

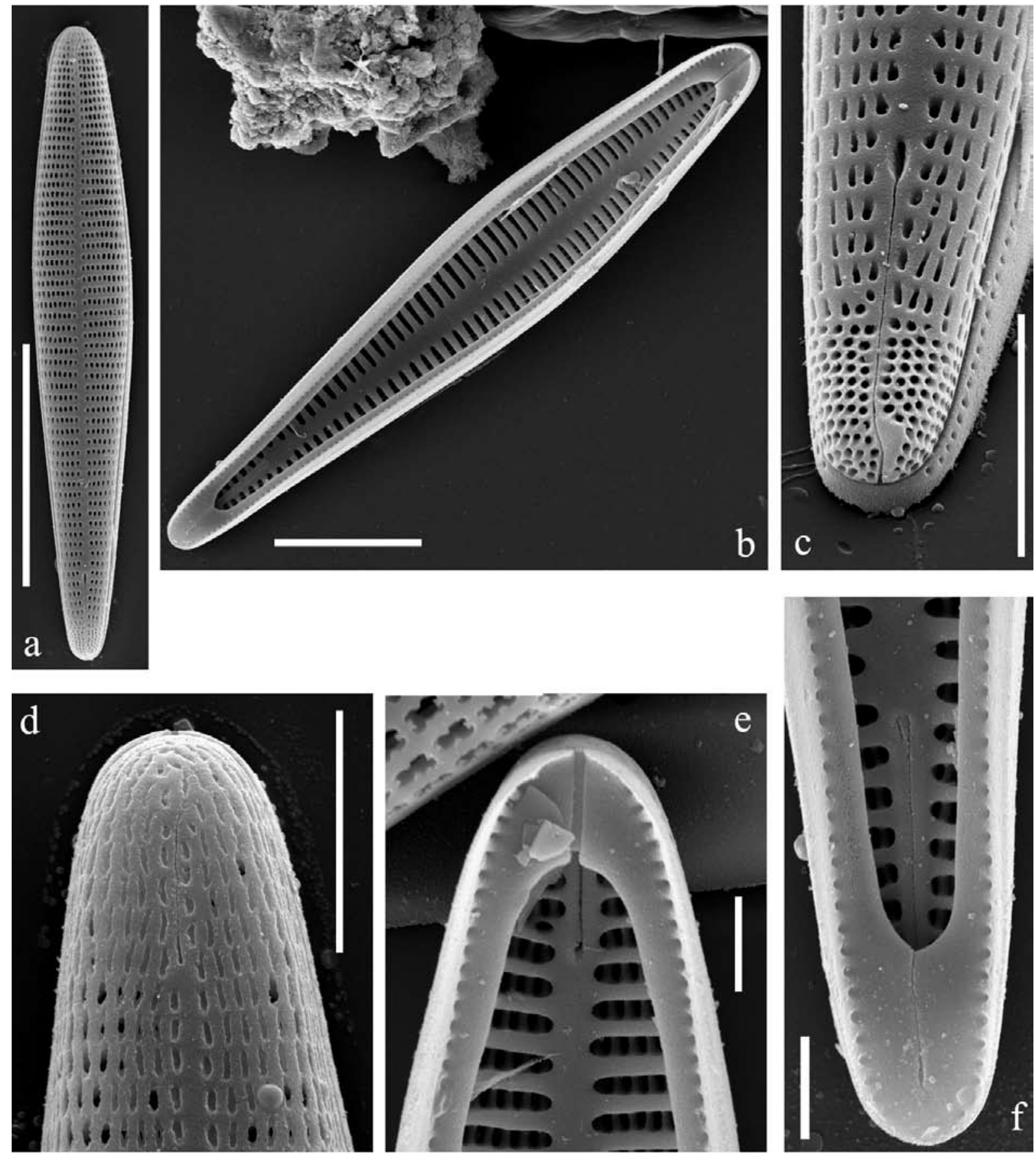

Figs 27a-f. Rhoicosphenia affinis, SEM convex D-valve: (27a) external view of whole valve, (27b) internal view of whole valve with valvocopula, (27c) base pole of Fig. 27a showing the slightly curved distal raphe fissure and apical pore field, (27d) detail of head pole showing the short raphe branch, proximally, the raphe branch terminates with an elongated proximal pore, (27e) internal view of the head pole showing the bent proximal raphe fissure, (27f) internal view of the base pole of Fig. 27b showing the bent proximal raphe fissure. Scale bar $20 \mu \mathrm{m}$ (Fig. 27a), $10 \mu \mathrm{m}$ (Fig. 27b), $5 \mu \mathrm{m}$ (Figs 27c, 27d), $2 \mu \mathrm{m}$ (Figs 27e, 27f). 


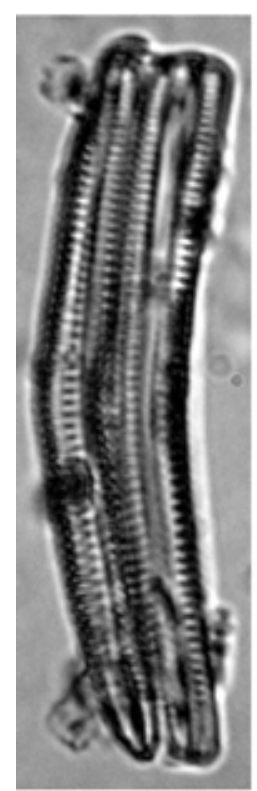

a

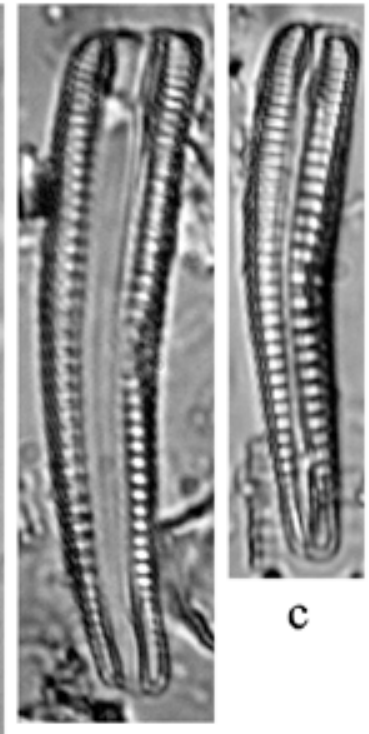

$\mathrm{b}$
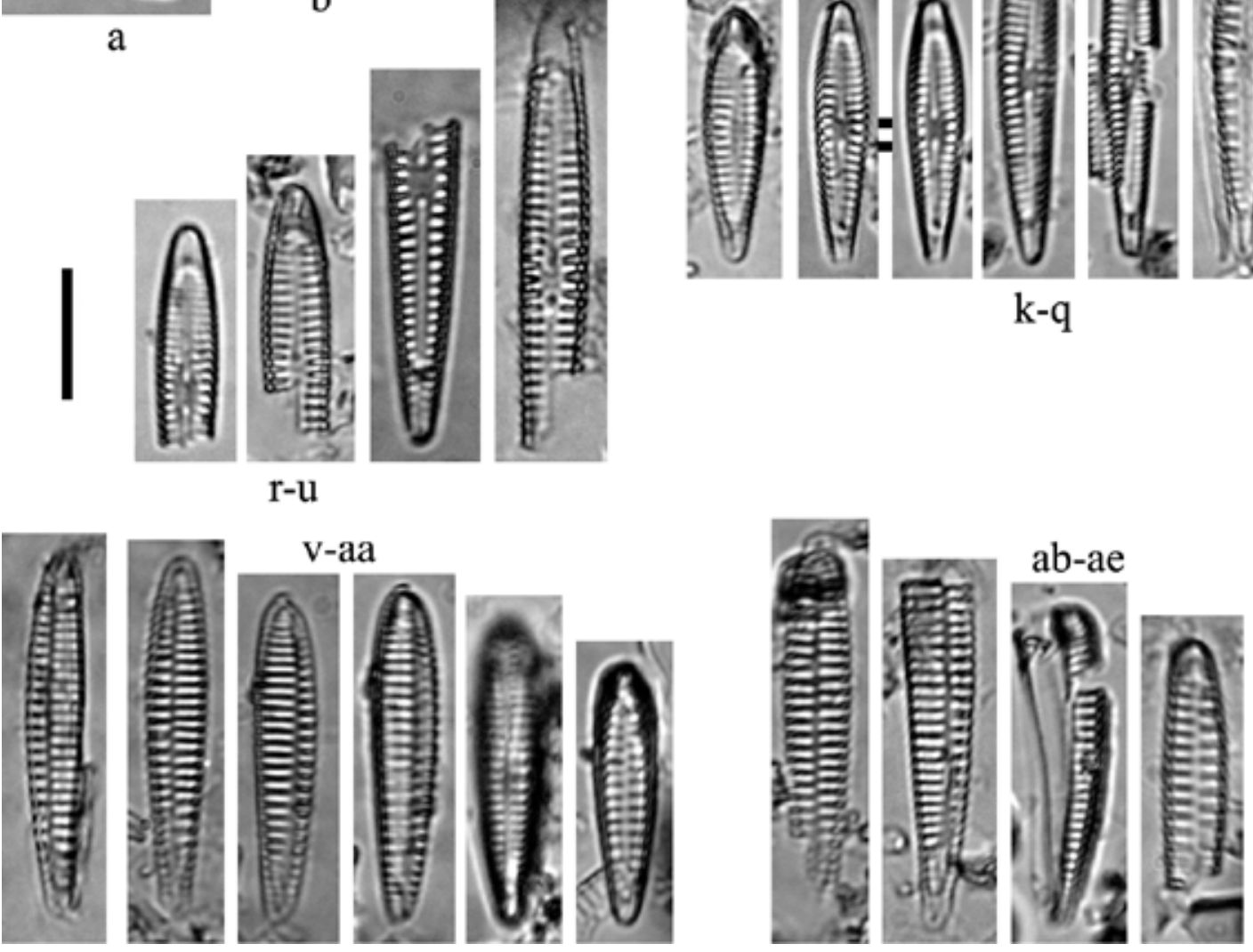

Figs 28a-ae. Rhoicosphenia fracta, LM, Königsberger Lager, Offene Süsswasser, slide No. ANSP 11214: (28a-c) frustules in girdle view, (28d-u) diminution series of the concave R-valve, (28v-ae) diminution series of the convex D-valve. Scale bar $10 \mu \mathrm{m}$. 

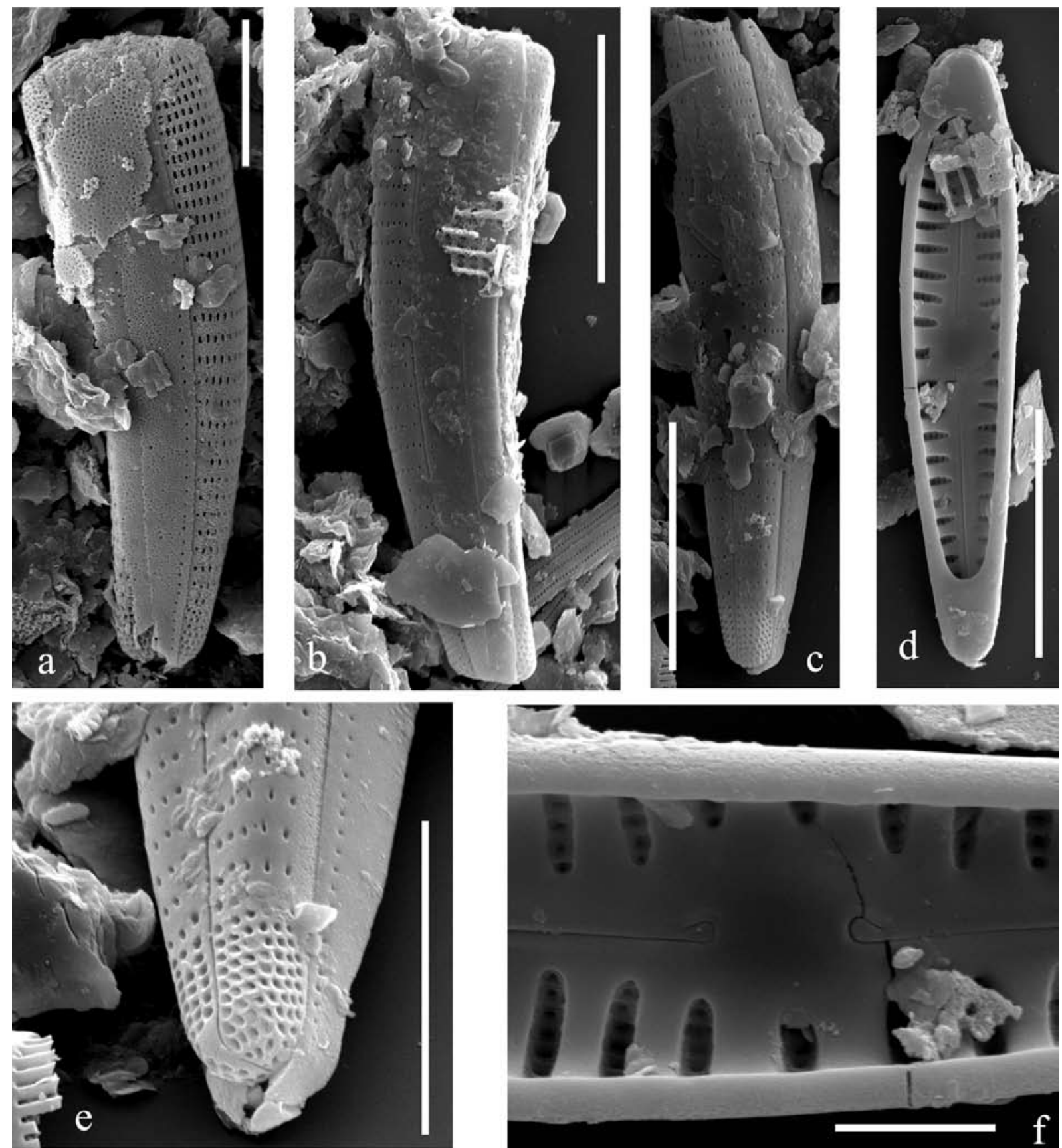

Figs 29a-f. Rhoicosphenia fracta, SEM, frustule and concave R-valve: (29a, 29b) frustule in girdle view, (29c) external valve view, (29d) internal view of the whole valve and pseudosepta, (29e) detail of the base pole showing the strongly curved distal raphe fissure and apical pore field, (29f) internal view of the valve centre showing the crook-shaped central fissures. Scale bar $5 \mu \mathrm{m}$ (Figs 29a, 29e), $10 \mu \mathrm{m}$ (Figs 29b, 29c, 29d), $2 \mu \mathrm{m}$ (Fig. 29f). 

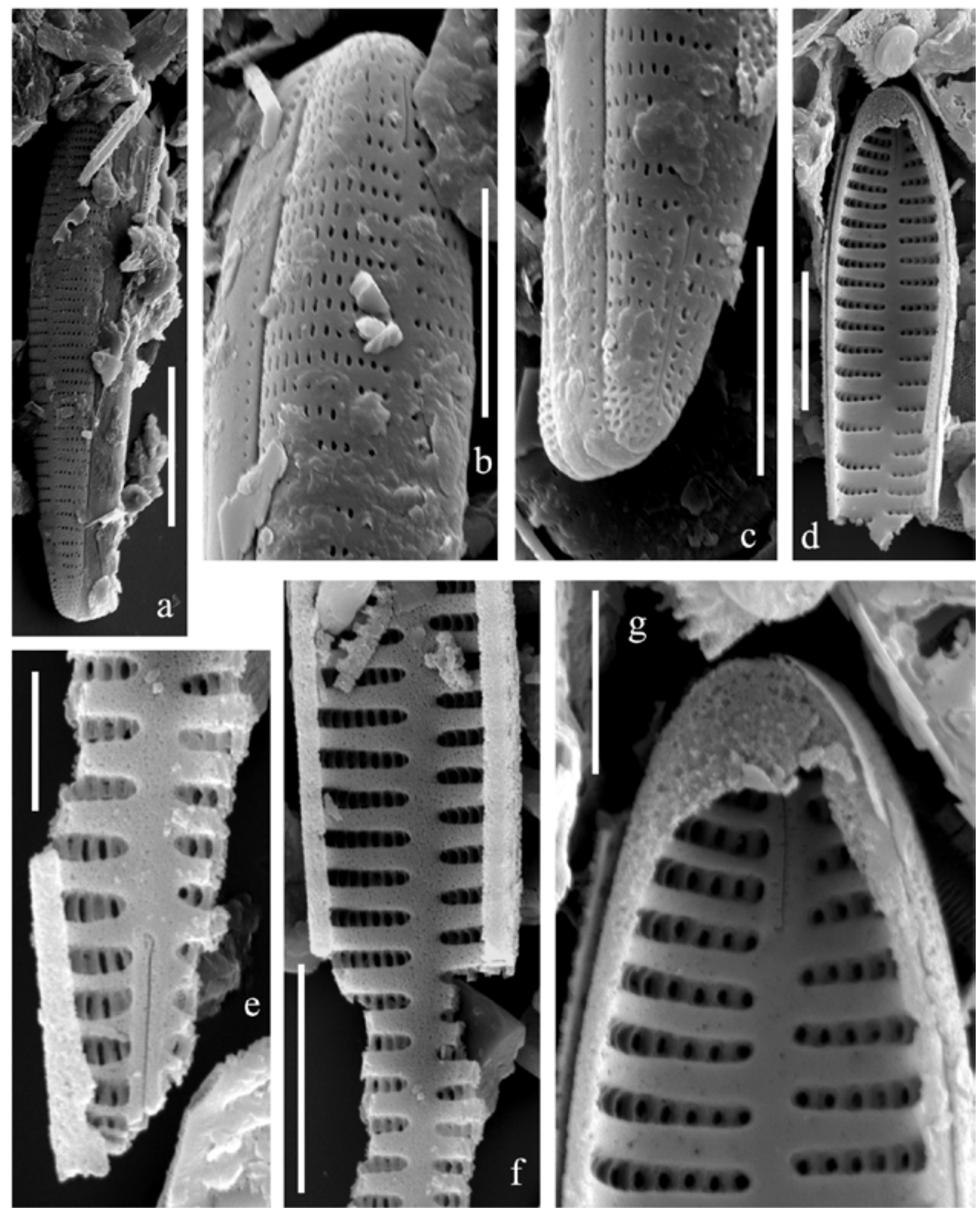

Figs 30a-g. Rhoicosphenia fracta, SEM, convex D-valve: (30a) external valve view, (30b) detail of the head pole showing the short raphe branch, (30c) detail of the base pole showing the slightly curved distal raphe fissure and apical pore field, (30d, $30 \mathrm{f}$ ) internal valve view of broken valves, (30e) internal view of the head pole showing the bent proximal raphe fissure, $(30 \mathrm{~g})$ internal view of the base pole showing the bent proximal raphe fissure. Scale bar $10 \mu \mathrm{m}$ (Fig. 30a), $5 \mu \mathrm{m}$ (Figs 30b-d, 30f), 2 $\mu \mathrm{m}$ (Figs 30e, 30g). 

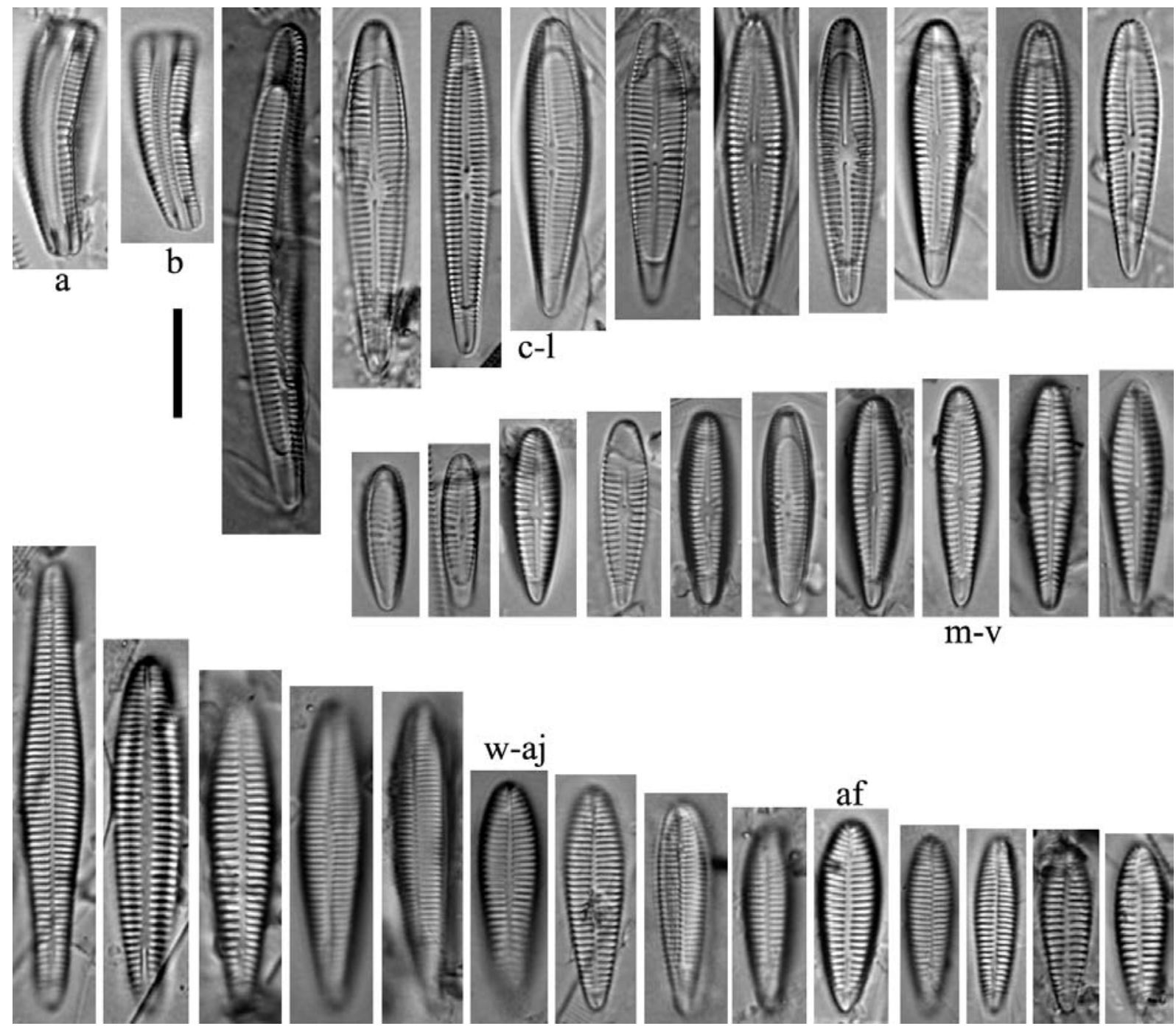

$\mathrm{m}-\mathrm{V}$
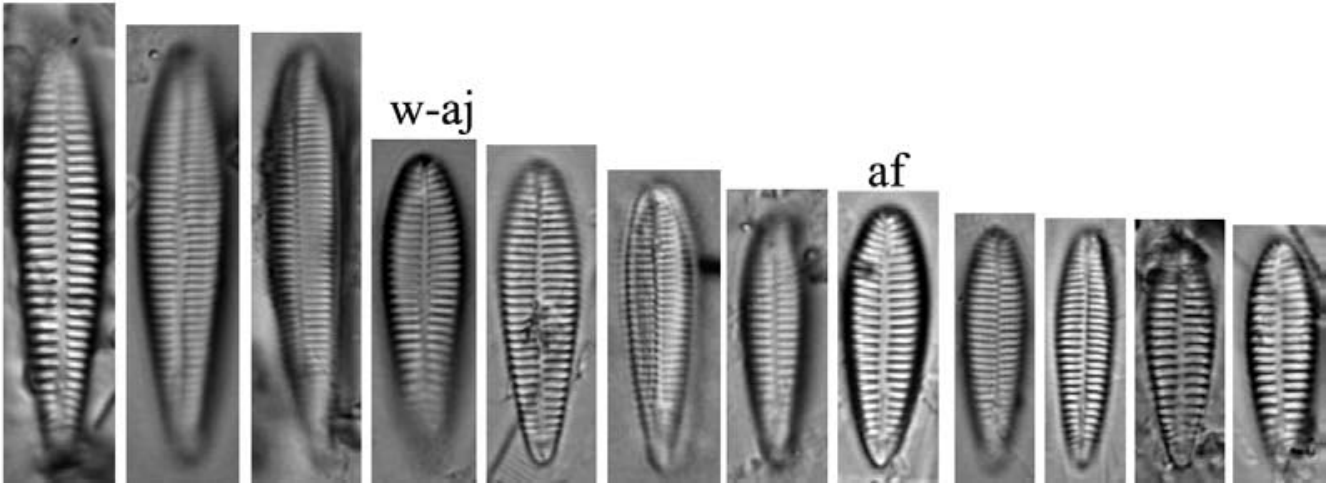

Figs 31a-aj. Rhoicosphenia adriatica, LM, Ombla River, Croatia, periphyton, $0.5 \mathrm{~m}$ depth: (31a, 31b) frustules in girdle view, $(31 \mathrm{c}-\mathrm{v})$ diminution series of the concave $\mathrm{R}-\mathrm{valve},(31 \mathrm{w}-\mathrm{aj})$ diminution series of the convex D-valve. Scale bar $10 \mu \mathrm{m}$. 

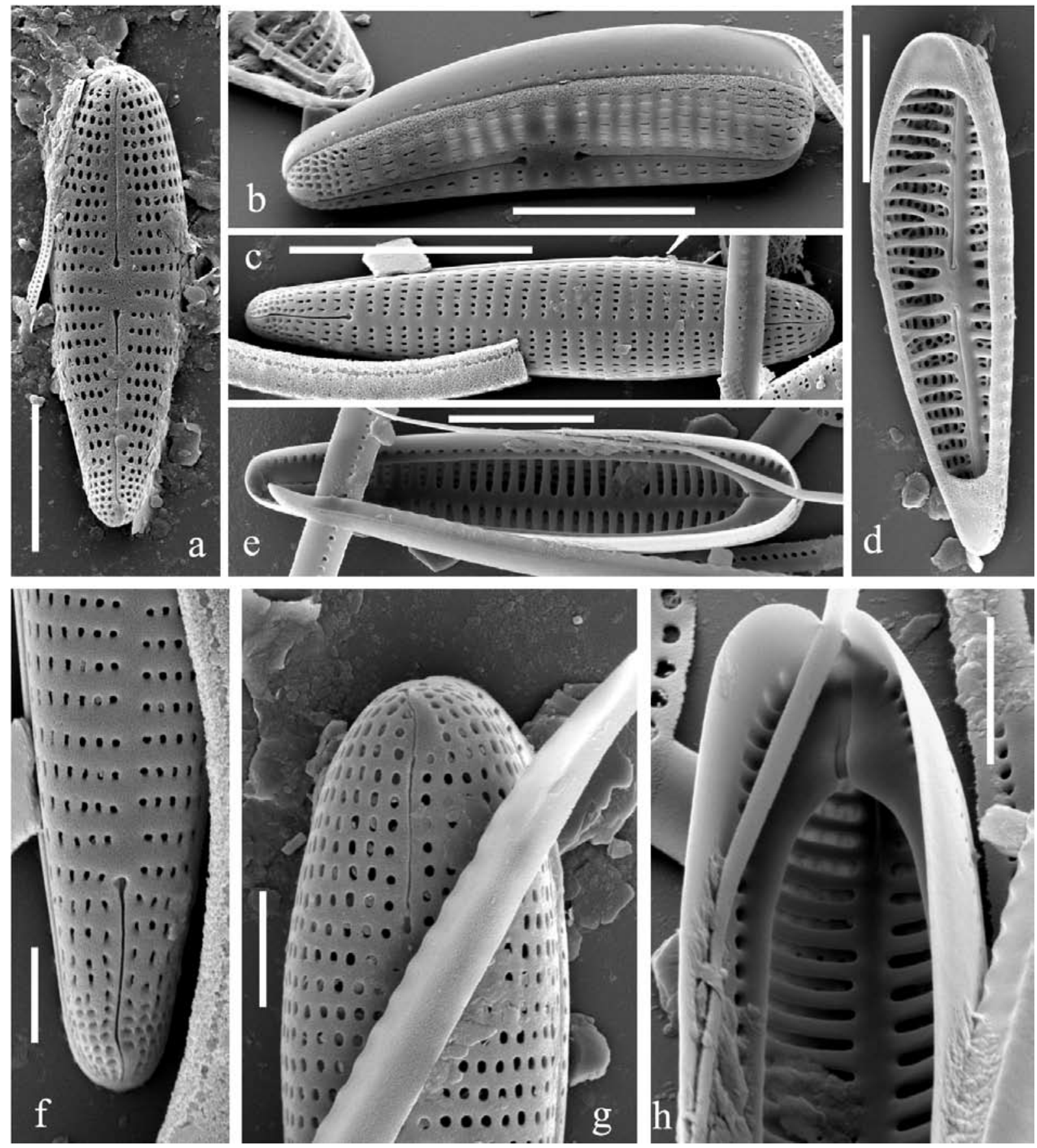

Figs 32a-h. Rhoicosphenia adriatica SEM, concave R-valve and convex D-valve: (32a, b) external view of concave R-valve, (32c) external view of convex D-valve, (32d) internal view of R-valve and pseudoseptum, (32e) internal view of D-valve and valvocopula, (32f) detail of base pole showing the curved distal raphe fissure and apical pore field, (32g) detail of head pole showing the short raphe branch, $(32 \mathrm{~h})$ internal view of the head pole showing the bent proximal raphe fissure. Scale bar $5 \mu \mathrm{m}$ (Figs 32a, b, d, e), $10 \mu \mathrm{m}$ (Figs 32c), $2 \mu \mathrm{m}$ (Figs 32f-h). 

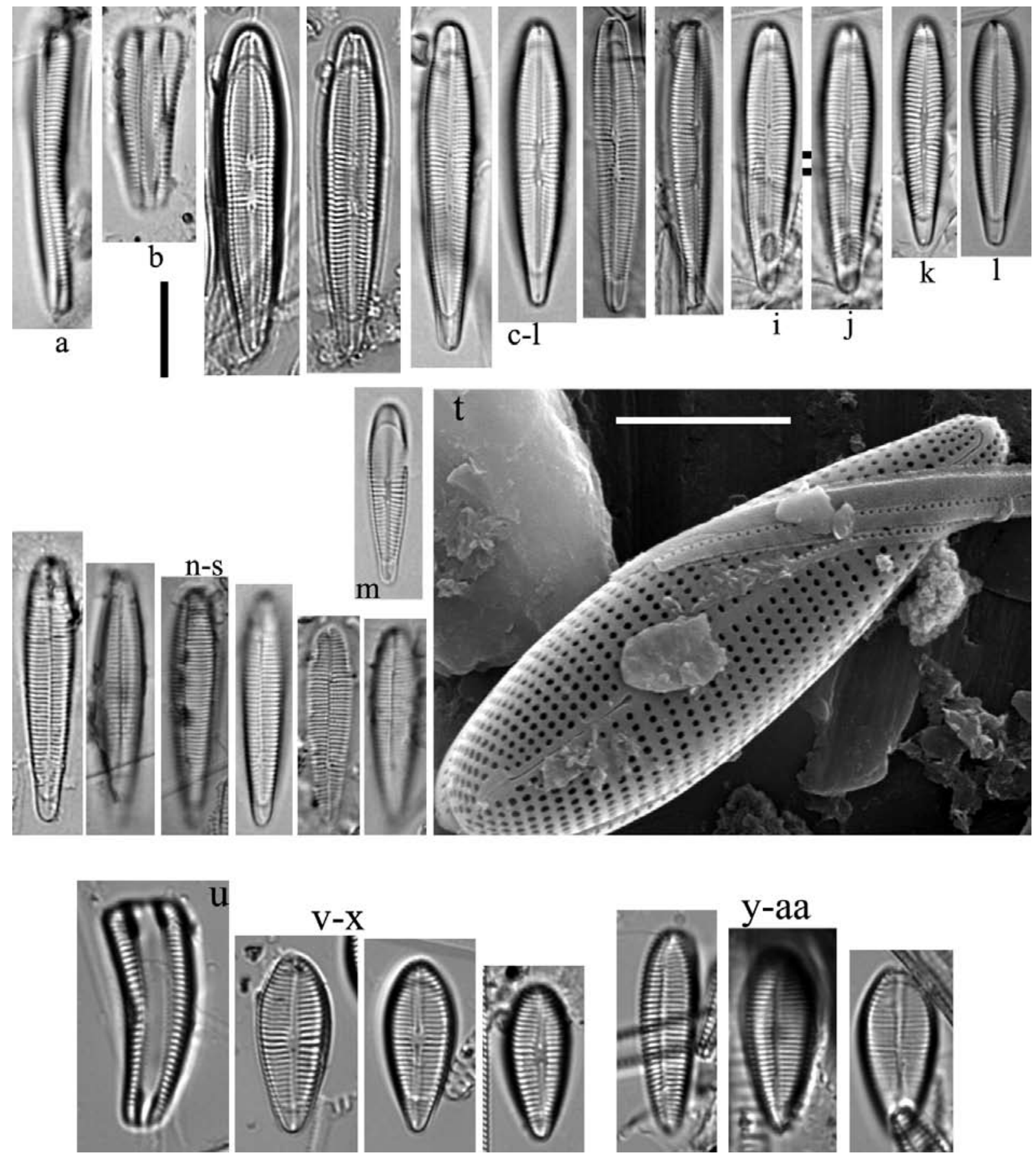

Figs 33a-aa. Two Rhoicosphenia species: (33a-t) Rhoicosphenia omblaensis, LM and SEM, River Ombla estuary, Eastern Adriatic coast, $(33 \mathrm{a}, 33 \mathrm{~b})$ frustules in girdle view, $(33 \mathrm{c}-\mathrm{m})$ diminution series of the concave $\mathrm{R}-\mathrm{valve}$, (33n-s) diminution series of the convex D-valve, (33t) SEM external view of D-valve; (33u-aa) Rhoicosphenia spec. 1, LM, (33u) frustule in girdle view, $(33 \mathrm{v}-\mathrm{x})$ diminution series of the concave R-valve, (33y-aa) diminution series of the convex D-valve. LM scale bar 10 $\mu \mathrm{m}$, SEM scale bar $5 \mu \mathrm{m}$ (Fig. 33t).

(C) Czech Phycological Society

Received September 22, 2009

Accepted April 12, 2010 